\title{
A New Way for Probing Bond Strength
}

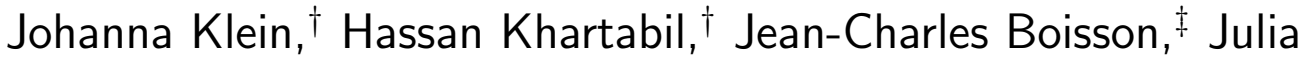

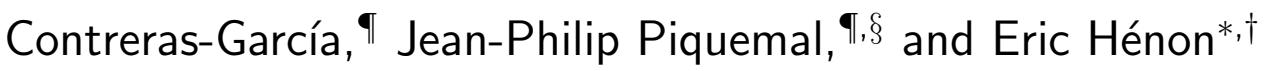

†Institut de Chimie Moléculaire de Reims UMR CNRS 7312, Université de Reims

Champagne-Ardenne, Moulin de la Housse 51687 Reims Cedex 02 BP39 (France)

$\ddagger$ CReSTIC EA 3804, Université de Reims Champagne-Ardenne, Moulin de la Housse

51687 Reims Cedex 02 BP39 (France)

\Sorbonne Université, Laboratoire de Chimie Théorique and UMR CNRS 7616, $4 \mathrm{Pl}$

Jussieu, 75252 Paris Cedex 05(France)

$\S$ Institut Universitaire de France, 75005, Paris, France

E-mail: eric.henon@univ-reims.fr

Phone: +33(3)26918497

\section{Contents}

1 IGM approach $\quad 3$

2 Molecule sets $\quad 3$

3 Influence of cylindrical grid density on the value of $\Delta g \quad 4$

4 Influence of the level of theory on the IBSI reference value for $H_{2} \quad 10$

5 Influence of the basis set on the value of $\Delta g \quad 12$

6 Influence of quantum mechanical method on the value of $\Delta g \quad 27$ 
7 IBSI compared with bond indices

8 IBSI across the periodic table

9 Localized bond stretching force constants

10 Correlation between the IBSI and force constants

11 Study of 677 bonds

12 Effect of polarization and diffuse functions on IBSI

$13 \mathrm{KC}-\mathrm{AIM}$ stretching force constant versus IBSI

63

$14 \mathrm{~B}_{2} \mathrm{H}_{6}$, cyclopropane, metallocene, agostic interaction

References 


\section{IGM approach}

The local $\delta g^{\text {pair }}$ descriptor was computed using a modified version of NCIPlot, the wavefunction being read from a WFN input file. To obtain its $\Delta g^{\text {pair }}$ integrated value, a grid is built. A cylinder is chosen, with its longitudinal axis coinciding with the bond axis, and a regular grid is built to encompass the bonding region between atoms. IGM quantities are calculated analytically at each grid point (ED and its derivatives). The use of such cylindrical grid allows to get rid of any potential grid orientation dependence on the resulting IBSI. The optimal resolution of the cylindrical grid was obtained based on case studies considering several kinds of chemical bond $(\sigma, \pi)$. The following sampling was used: $n_{z}=100, n_{\theta}=50$, $n_{r}=100$ along the cylindrical coordinates. Compared to the conventional parallelepiped spanning the whole molecule, this high resolution cylindrical grid applied to each studied bond results in an higher CPU-cost but also in an improved accuracy of the IBSI. Such grid computational scheme could leverage the massively parallel GPU technology for the acceleration of $\delta g$ calculation, as demonstrated with NCI in a previous study. ${ }^{1}$ As aforementioned, the $\Delta g^{\text {pair }}$ integral is then numerically estimated as the sum of $\delta g^{\text {pair }} d V$ elements divided by the square of the internuclear distance for the studied bond and finally normalized by dividing the resulting score by a constant $\left(\int_{V} \frac{\delta g^{H_{2}}}{d_{H_{2}}^{2}} d V\right)$.

\section{Molecule sets}

Three sets of molecules have been considered:

\begin{tabular}{cccc}
\hline & Set1 & Set2 & $($ Set1 + Set2 $)=$ Set3 \\
\hline Presence of rings & NO & YES & MIX \\
\hline Number of molecules & 184 & 51 & 235 \\
Number of bonds & 438 & 239 & 677 \\
$\mathrm{k}$ & $k_{1}, k_{2}$ & $k_{2}$ & $k_{2}$ \\
\hline
\end{tabular}

In the following, the $k_{1}$ and $k_{2}$ local force constants have been obtained using the set1 of 
molecules containing no ring. It is recalled that $k_{1}$ cannot be computed for bonds belonging to a ring. $k_{2}$ has also been calculated for the set2 of 51 ring-containing molecules (239 bonds).

\section{Influence of cylindrical grid density on the value of $\Delta g$}

In this work we have used a cylindrical grid. For each studied chemical bond a cylinder is chosen, with its longitudinal axis coinciding with the bond axis and a regular grid is built to encompass the bonding region between the two atoms. Three parameters govern the total number of points: $P_{z}, P_{\theta}, P_{r}$, representing the axial, angular and radial directions, respectively. The optimal resolution of the grid has been obtained based on case studies considering the $\sigma \mathrm{O}-\mathrm{H}$ bond in water and the $\mathrm{C}-\mathrm{C}$ bond with partial $\pi$ character in benzene. At the beginning of our study, the tests were performed at the B3LYP/6-31G* level of theory. For each triplet $\left(P_{z}, P_{r}, P_{\theta}\right)$ reported in the table, the first derivative of the integral

quantity $\Delta g^{\text {pair }}\left(\int_{V} \delta g^{\text {pair }} d V\right)$ with respect to each of the parameters has been calculated. It has been numerically obtained by slightly changing the number of points along the chosen direction. It is to be noted that $\Delta g^{\text {pair }}$ does not exactly correspond here to the IBSI index since the integral is not divided by the square of the internuclear distance. This was done to only test the influence of the grid resolution on the integral. Also, the computation time is reported. The reference triplet taken for all the subsequent calculations is $\left(P_{z}=100\right.$, $P_{r}=100, P_{\theta}=50$, indicated by a red point in the table). From our calculations, it appears that the most sensitive parameter is $n_{r}$, i.e. the number of points along the radial direction. 
Calculation Level B3LYP/6-31G**

\begin{tabular}{|c|c|c|c|c|c|}
\hline & Value & $\partial \Delta g / \partial P z$ & $\partial \Delta g / \partial P r$ & $\partial \Delta g / \partial P$ theta & Time (min.) \\
\hline $\mathrm{Pz}$ & 1 & \multirow{3}{*}{$x$} & \multirow{3}{*}{$x$} & \multirow{3}{*}{$x$} & \multirow{3}{*}{0} \\
\hline $\operatorname{Pr}$ & 1 & & & & \\
\hline Ptheta & 1 & & & & \\
\hline $\mathrm{Pz}$ & 5 & \multirow{3}{*}{$x$} & \multirow{3}{*}{$x$} & \multirow{3}{*}{$x$} & \multirow{3}{*}{0} \\
\hline $\mathrm{Pr}$ & 1 & & & & \\
\hline Ptheta & 1 & & & & \\
\hline $\mathrm{Pz}$ & 1 & \multirow{3}{*}{$-3,476 \mathrm{E}-01$} & \multirow{3}{*}{ 2,636E-01 } & \multirow{3}{*}{ 1,274E-02 } & \multirow{3}{*}{0} \\
\hline $\mathrm{Pr}$ & 5 & & & & \\
\hline Ptheta & 1 & & & & \\
\hline $\mathrm{Pz}$ & 1 & \multirow{3}{*}{$x$} & \multirow{3}{*}{$x$} & \multirow{3}{*}{$x$} & \multirow{3}{*}{0} \\
\hline $\mathrm{Pr}$ & 1 & & & & \\
\hline Ptheta & 5 & & & & \\
\hline $\mathrm{Pz}$ & 5 & \multirow{3}{*}{ 3,744E-01 } & \multirow{3}{*}{ 4,942E-01 } & \multirow{3}{*}{ 3,897E-01 } & \multirow{3}{*}{0} \\
\hline $\mathrm{Pr}$ & 5 & & & & \\
\hline Ptheta & 1 & & & & \\
\hline $\mathrm{Pz}$ & 5 & \multirow{3}{*}{$x$} & \multirow{3}{*}{$x$} & \multirow{3}{*}{$x$} & \multirow{3}{*}{0} \\
\hline $\mathrm{Pr}$ & 1 & & & & \\
\hline Ptheta & 5 & & & & \\
\hline $\mathrm{Pz}$ & 1 & \multirow{3}{*}{$-3,864 \mathrm{E}-01$} & & & \\
\hline $\mathrm{Pr}$ & 5 & & $8,156 \mathrm{E}-01$ & 5,996E-01 & 0 \\
\hline Ptheta & 5 & & & & \\
\hline $\mathrm{Pz}$ & 5 & & & & \\
\hline $\mathrm{Pr}$ & 5 & 3,636E-01 & 4,859E-01 & 3,725E-01 & 0 \\
\hline Ptheta & 5 & & & & \\
\hline $\mathrm{Pz}$ & 10 & & & & \\
\hline $\mathrm{Pr}$ & 5 & $-3,611 E-01$ & 4,827E-01 & 3,694E-01 & 0 \\
\hline Ptheta & 5 & & & & \\
\hline $\mathrm{Pz}$ & 5 & & & & \\
\hline $\mathrm{Pr}$ & 10 & $-7,144 \mathrm{E}-01$ & 7,267E-01 & $-7,121 \mathrm{E}-01$ & 0 \\
\hline Ptheta & 5 & & & & \\
\hline $\mathrm{Pz}$ & 5 & & & & \\
\hline $\mathrm{Pr}$ & 5 & -3,682E-01 & 4,890E-01 & $-3,684 \mathrm{E}-01$ & 0 \\
\hline Ptheta & 10 & & & & \\
\hline $\mathrm{Pz}$ & 10 & & & & \\
\hline $\mathrm{Pr}$ & 10 & $-7,058 \mathrm{E}-01$ & 7,187E-01 & 7,046E-01 & 0 \\
\hline Ptheta & 5 & & & & \\
\hline $\mathrm{Pz}$ & 10 & & & & \\
\hline $\mathrm{Pr}$ & 5 & 3,662E-01 & 4,856E-01 & 3,664E-01 & 0 \\
\hline Ptheta & 10 & & & & \\
\hline $\mathrm{Pz}$ & 5 & & & & \\
\hline $\mathrm{Pr}$ & 10 & 7,154E-01 & 7,298E-01 & 7,200E-01 & 0 \\
\hline Ptheta & 10 & & & & \\
\hline
\end{tabular}




\begin{tabular}{|c|c|c|c|c|c|}
\hline $\mathrm{Pz}$ & 10 & \multirow{3}{*}{ 7,078E-01 } & \multirow{3}{*}{ 7,219E-01 } & \multirow{3}{*}{$7,080 \mathrm{E}-01$} & \multirow{3}{*}{0} \\
\hline $\mathrm{Pr}$ & 10 & & & & \\
\hline Ptheta & 10 & & & & \\
\hline $\mathrm{Pz}$ & 20 & \multirow{3}{*}{ 7,057E-01 } & \multirow{3}{*}{ 7,191E-01 } & \multirow{3}{*}{ 7,060E-01 } & \multirow{3}{*}{0} \\
\hline $\mathrm{Pr}$ & 10 & & & & \\
\hline Ptheta & 10 & & & & \\
\hline $\mathrm{Pz}$ & 10 & \multirow{3}{*}{ 7,823E-01 } & \multirow{3}{*}{ 7,858E-01 } & \multirow{3}{*}{ 7,825E-01 } & \multirow{3}{*}{0} \\
\hline $\mathrm{Pr}$ & 20 & & & & \\
\hline Ptheta & 10 & & & & \\
\hline $\mathrm{Pz}$ & 10 & \multirow{3}{*}{ 7,072E-01 } & \multirow{3}{*}{ 7,231E-01 } & \multirow{3}{*}{ 7,065E-01 } & \multirow{3}{*}{0} \\
\hline $\mathrm{Pr}$ & 10 & & & & \\
\hline Ptheta & 20 & & & & \\
\hline $\mathrm{Pz}$ & 20 & \multirow{3}{*}{ 7,838E-01 } & \multirow{3}{*}{ 7,872E-01 } & \multirow{3}{*}{ 7,834E-01 } & \multirow{3}{*}{0} \\
\hline $\mathrm{Pr}$ & 20 & & & & \\
\hline Ptheta & 10 & & & & \\
\hline $\mathrm{Pz}$ & 20 & \multirow{3}{*}{ 7,051E-01 } & \multirow{3}{*}{ 7,199E-01 } & & \\
\hline $\mathrm{Pr}$ & 10 & & & $7,050 \mathrm{E}-01$ & 0 \\
\hline Ptheta & 20 & & & & \\
\hline $\mathrm{Pz}$ & 10 & & & & \\
\hline $\mathrm{Pr}$ & 20 & 7,820E-01 & 7,857E-01 & 7,817E-01 & 0 \\
\hline Ptheta & 20 & & & & \\
\hline $\mathrm{Pz}$ & 20 & & & & \\
\hline $\mathrm{Pr}$ & 20 & 2,685E-04 & 3,613E-03 & $5,160 \mathrm{E}-04$ & 0 \\
\hline Ptheta & 20 & & & & \\
\hline $\mathrm{Pz}$ & 50 & & & & \\
\hline $\mathrm{Pr}$ & 20 & $1,239 \mathrm{E}-04$ & 5,459E-03 & $4,806 \mathrm{E}-04$ & 1 \\
\hline Ptheta & 20 & & & & \\
\hline $\mathrm{Pz}$ & 20 & & & & \\
\hline $\mathrm{Pr}$ & 50 & 3,911E-05 & 3,867E-04 & $4,129 \mathrm{E}-04$ & 1 \\
\hline Ptheta & 20 & & & & \\
\hline $\mathrm{Pz}$ & 20 & & & & \\
\hline $\mathrm{Pr}$ & 20 & $5,600 \mathrm{E}-04$ & $3,725 \mathrm{E}-03$ & $3,200 E-05$ & 1 \\
\hline Ptheta & 50 & & & & \\
\hline $\mathrm{Pz}$ & 50 & & & & \\
\hline $\mathrm{Pr}$ & 50 & 5,410E-05 & $1,068 \mathrm{E}-04$ & 4,739E-04 & 4 \\
\hline Ptheta & 20 & & & & \\
\hline $\mathrm{Pz}$ & 50 & & & & \\
\hline $\mathrm{Pr}$ & 20 & 2,914E-05 & $3,496 \mathrm{E}-03$ & 4,582E-05 & 4 \\
\hline Ptheta & 50 & & & & \\
\hline $\mathrm{Pz}$ & 20 & & & & \\
\hline $\mathrm{Pr}$ & 50 & 1,464E-05 & 4,900E-07 & 2,877E-05 & 4 \\
\hline Ptheta & 50 & & & & \\
\hline $\mathrm{Pz}$ & 50 & & & & \\
\hline $\mathrm{Pr}$ & 50 & 4,785E-05 & $5,453 \mathrm{E}-04$ & 1,972E-05 & 4 \\
\hline Ptheta & 50 & & & & \\
\hline $\mathrm{Pz}$ & 100 & & & & \\
\hline $\mathrm{Pr}$ & 20 & 9,640E-06 & 3,511E-03 & 4,855E-04 & 4 \\
\hline Ptheta & 20 & & & & \\
\hline
\end{tabular}




\begin{tabular}{|c|c|c|c|c|c|}
\hline $\mathrm{Pz}$ & 100 & \multirow{3}{*}{ 2,667E-05 } & \multirow{3}{*}{ 6,685E-05 } & \multirow{3}{*}{ 4,779E-04 } & \multirow{3}{*}{4} \\
\hline $\operatorname{Pr}$ & 50 & & & & \\
\hline Ptheta & 20 & & & & \\
\hline $\mathrm{Pz}$ & 100 & \multirow{3}{*}{ 7,550E-06 } & \multirow{3}{*}{ 3,510E-03 } & \multirow{3}{*}{ 3,554E-05 } & \multirow{3}{*}{4} \\
\hline $\mathrm{Pr}$ & 20 & & & & \\
\hline Ptheta & 50 & & & & \\
\hline $\mathrm{Pz}$ & 100 & \multirow{3}{*}{ 1,814E-05 } & \multirow{3}{*}{ 2,570E-05 } & \multirow{3}{*}{ 2,361E-04 } & \multirow{3}{*}{8} \\
\hline $\mathrm{Pr}$ & 50 & & & & \\
\hline Ptheta & 50 & & & & \\
\hline $\mathrm{Pz}$ & 20 & \multirow{3}{*}{ 2,718E-04 } & \multirow{3}{*}{ 7,048E-05 } & \multirow{3}{*}{ 4,313E-04 } & \multirow{3}{*}{2} \\
\hline $\mathrm{Pr}$ & 100 & & & & \\
\hline Ptheta & 20 & & & & \\
\hline $\mathrm{Pz}$ & 50 & \multirow{3}{*}{ 7,543E-05 } & \multirow{3}{*}{ 6,364E-05 } & \multirow{3}{*}{ 4,714E-04 } & \multirow{3}{*}{5} \\
\hline $\mathrm{Pr}$ & 100 & & & & \\
\hline Ptheta & 20 & & & & \\
\hline $\mathrm{Pz}$ & 20 & \multirow{3}{*}{ 2,326E-04 } & \multirow{3}{*}{ 3,108E-05 } & & \\
\hline $\mathrm{Pr}$ & 100 & & & 3,234E-04 & 5 \\
\hline Ptheta & 50 & & & & \\
\hline $\mathrm{Pz}$ & 50 & & & & \\
\hline $\mathrm{Pr}$ & 100 & 4,171E-05 & 2,805E-05 & 2,593E-05 & 9 \\
\hline Ptheta & 50 & & & & \\
\hline $\mathrm{Pz}$ & 20 & & & & \\
\hline $\mathrm{Pr}$ & 20 & $5,990 \mathrm{E}-04$ & 3,763E-03 & 3,718E-05 & 2 \\
\hline Ptheta & 100 & & & & \\
\hline $\mathrm{Pz}$ & 50 & & & & \\
\hline $\mathrm{Pr}$ & 20 & 1,485E-05 & 3,523E-02 & 4,642E-05 & 4 \\
\hline Ptheta & 100 & & & & \\
\hline $\mathrm{Pz}$ & 20 & & & & \\
\hline $\mathrm{Pr}$ & 50 & 4,410E-05 & 2,736E-05 & 3,885E-05 & 4 \\
\hline Ptheta & 100 & & & & \\
\hline $\mathrm{Pz}$ & 50 & & & & \\
\hline $\mathrm{Pr}$ & 50 & 5,215E-05 & 4,212E-05 & 3,772E-05 & 9 \\
\hline Ptheta & 100 & & & & \\
\hline $\mathrm{Pz}$ & 100 & & & & \\
\hline $\mathrm{Pr}$ & 100 & 4,701E-05 & 8,006E-05 & 4,729E-04 & 9 \\
\hline Ptheta & 20 & & & & \\
\hline $\mathrm{Pz}$ & 100 & & & & \\
\hline $\mathrm{Pr}$ & 100 & 1,978E-05 & 3,437E-05 & 3,087E-05 & 18 \\
\hline Ptheta & 50 & & & & \\
\hline $\mathrm{Pz}$ & 100 & & & & \\
\hline $\mathrm{Pr}$ & 20 & 1,857E-05 & 3,541E-03 & 4,204E-05 & 8 \\
\hline Ptheta & 100 & & & & \\
\hline $\mathrm{Pz}$ & 100 & & & & \\
\hline $\mathrm{Pr}$ & 50 & 1,620E-05 & 1,419E-05 & 4,338E-05 & 16 \\
\hline Ptheta & 100 & & & & \\
\hline & 20 & & & & \\
\hline $\mathrm{Pr}$ & $\frac{20}{100}$ & $2230 \mathrm{E}-04$ & 3.970E-05 & & \\
\hline $\mathrm{Pr}$ & 100 & & & 3,723E-05 & 6 \\
\hline
\end{tabular}




\begin{tabular}{|c|c|c|c|c|c|}
\hline Ptheta & 100 & & & & \\
\hline $\mathrm{Pz}$ & 50 & \multirow{3}{*}{ 4,032E-05 } & \multirow{3}{*}{ 2,869E-05 } & \multirow{3}{*}{ 3,807E-05 } & \multirow{3}{*}{18} \\
\hline $\mathrm{Pr}$ & 100 & & & & \\
\hline Ptheta & 100 & & & & \\
\hline $\mathrm{Pz}$ & 100 & \multirow{3}{*}{ 1,535E-05 } & \multirow{3}{*}{ 3,626E-05 } & \multirow{3}{*}{ 4,312E-05 } & \multirow{3}{*}{36} \\
\hline $\mathrm{Pr}$ & 100 & & & & \\
\hline Ptheta & 100 & & & & \\
\hline
\end{tabular}



SIGMA BOND
(H2O;O-H BOND)

Calculation Level: $\quad$ B3LYP/6-31G**

\begin{tabular}{|c|c|c|c|c|c|}
\hline & Value & $\partial \Delta g / \partial P z$ & $\partial \Delta \mathrm{g} / \partial \mathrm{Pr}$ & $\partial \Delta g / \partial$ Ptheta & Times (min.) \\
\hline $\mathrm{Pz}$ & 50 & \multirow{3}{*}{ 6,000E-06 } & \multirow{3}{*}{$4,160 \mathrm{E}-03$} & \multirow{3}{*}{$1,000 \mathrm{E}-06$} & \multirow{3}{*}{0} \\
\hline $\mathrm{Pr}$ & 20 & & & & \\
\hline Ptheta & 50 & & & & \\
\hline $\mathrm{Pz}$ & 20 & \multirow{3}{*}{ 1,900E-05 } & \multirow{3}{*}{ 2,870E-04 } & \multirow{3}{*}{$1,000 \mathrm{E}-07$} & \multirow{3}{*}{0} \\
\hline $\mathrm{Pr}$ & 50 & & & & \\
\hline Ptheta & 50 & & & & \\
\hline $\mathrm{Pz}$ & 50 & \multirow{3}{*}{ 1,000E-05 } & \multirow{3}{*}{ 3,800E-05 } & \multirow{3}{*}{ 1,000E-06 } & \multirow{3}{*}{0} \\
\hline $\mathrm{Pr}$ & 100 & & & & \\
\hline Ptheta & 50 & & & & \\
\hline $\mathrm{Pz}$ & 100 & \multirow{3}{*}{ 1,000E-06 } & \multirow{3}{*}{ 2,750E-04 } & \multirow{3}{*}{ 1,000E-06 } & \multirow{3}{*}{0} \\
\hline $\mathrm{Pr}$ & 50 & & & & \\
\hline Ptheta & 50 & & & & \\
\hline $\mathrm{Pz}$ & 100 & \multirow{3}{*}{ 1,000E-06 } & \multirow{3}{*}{ 4,134E-03 } & \multirow{3}{*}{$1,000 \mathrm{E}-07$} & \multirow{3}{*}{0} \\
\hline $\mathrm{Pr}$ & 20 & & & & \\
\hline Ptheta & 100 & & & & \\
\hline $\mathrm{Pz}$ & 20 & \multirow{3}{*}{ 1,100E-05 } & \multirow{3}{*}{ 3,200E-05 } & \multirow{3}{*}{$1,000 \mathrm{E}-07$} & \multirow{3}{*}{0} \\
\hline $\mathrm{Pr}$ & 100 & & & & \\
\hline Ptheta & 100 & & & & \\
\hline $\mathrm{Pz}$ & 20 & \multirow{3}{*}{ 4,000E-05 } & \multirow{3}{*}{ 3,100E-05 } & \multirow{3}{*}{ 2,200E-05 } & \multirow{3}{*}{0} \\
\hline $\mathrm{Pr}$ & 100 & & & & \\
\hline Ptheta & 20 & & & & \\
\hline $\mathrm{Pz}$ & 100 & \multirow{3}{*}{ 4,000E-06 } & \multirow{3}{*}{ 4,132E-03 } & \multirow{3}{*}{ 1,300E-05 } & \\
\hline $\mathrm{Pr}$ & 20 & & & & 0 \\
\hline Ptheta & 20 & & & & \\
\hline $\mathrm{Pz}$ & 50 & & & & \\
\hline $\mathrm{Pr}$ & 100 & 1,000E-05 & 3,800E-05 & 1,000E-06 & 0 \\
\hline Ptheta & 50 & & & & \\
\hline $\mathrm{Pz}$ & 100 & & & & \\
\hline $\mathrm{Pr}$ & 100 & $6,000 \mathrm{E}-08$ & 3,500E-05 & 6,000E-09 & 2 \\
\hline Ptheta & 50 & & & & \\
\hline
\end{tabular}




\section{Influence of the level of theory on the IBSI reference value for $H_{2}$}

The influence of the level of theory on the gross value of $\int_{V} \delta g^{H_{2}} d V$ has been studied for two standard DFT functionals and for the MP2 level of theory, for 7 different basis sets. As can be seen, the gross sum $\int_{V} \delta g^{H_{2}} d V$ is hardly dependent on both the basis set and level of theory. We however advise not using the cc-pvdz basis set. The M06-2X/6-31G** level has been chosen in this work for the subsequent calculations. This popular functional is recommended for applications involving main-group elements and non-covalent interactions. Although the IBSI value for $H_{2}$ is rather stable, it is recommended to employ the same level of theory to compare IBSI values across different molecules. 


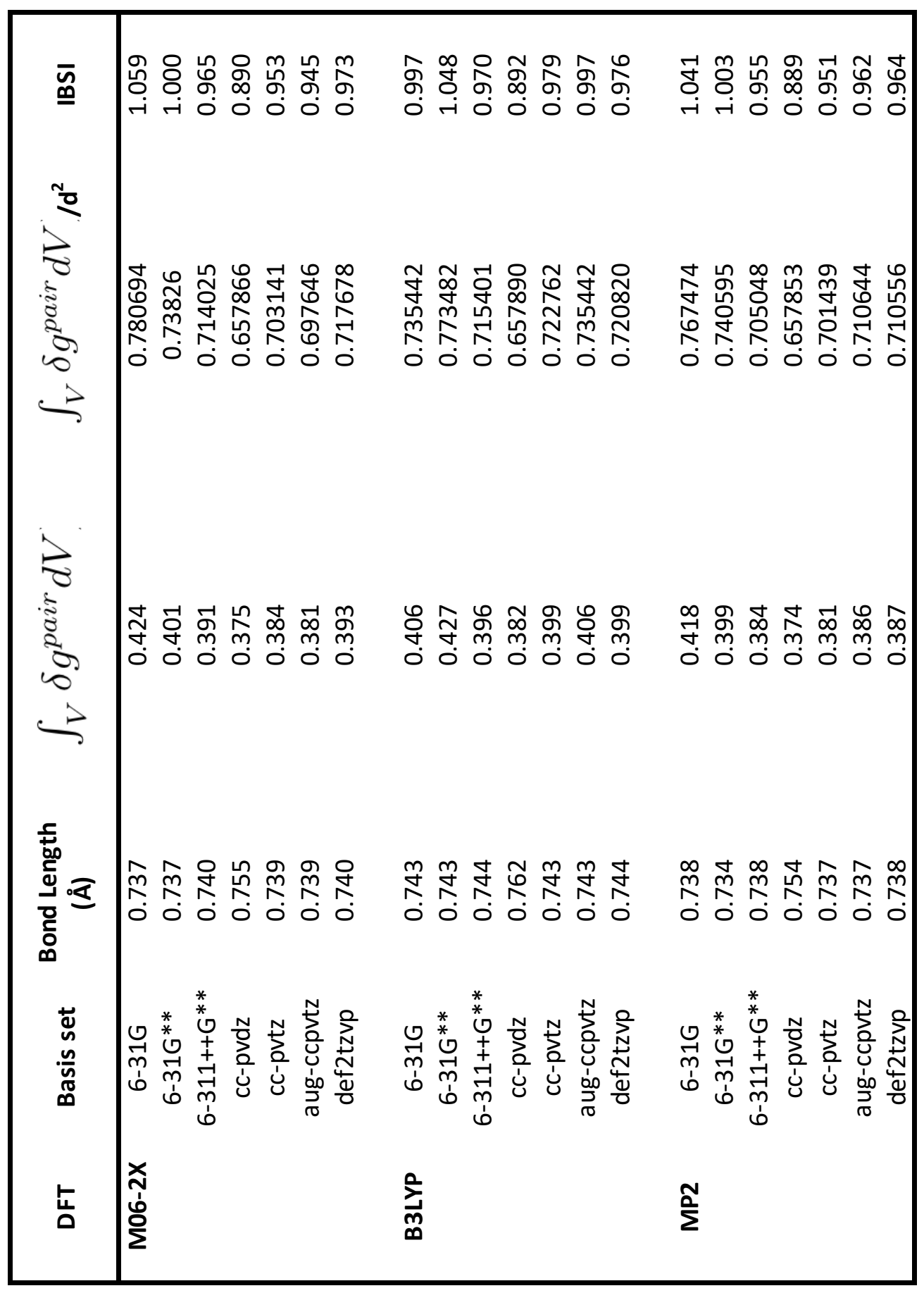




\section{Influence of the basis set on the value of $\Delta g$}

Case studies have been carried out to address the influence of the basis set on the value of $\Delta g^{\text {pair }}$. A total of 9 molecules has been considered, covering different kinds of chemical bonds. The value of $\Delta g^{\text {pair }}$ is shown to be hardly dependent on the basis set. For each test, the worst result (furthest away from the $\Delta g^{\text {pair }}$ average) is indicated with a red line. We recommend the use of $6-31 \mathrm{G}^{* *}$, and we strongly advise not to use the STO-3G basis set. 


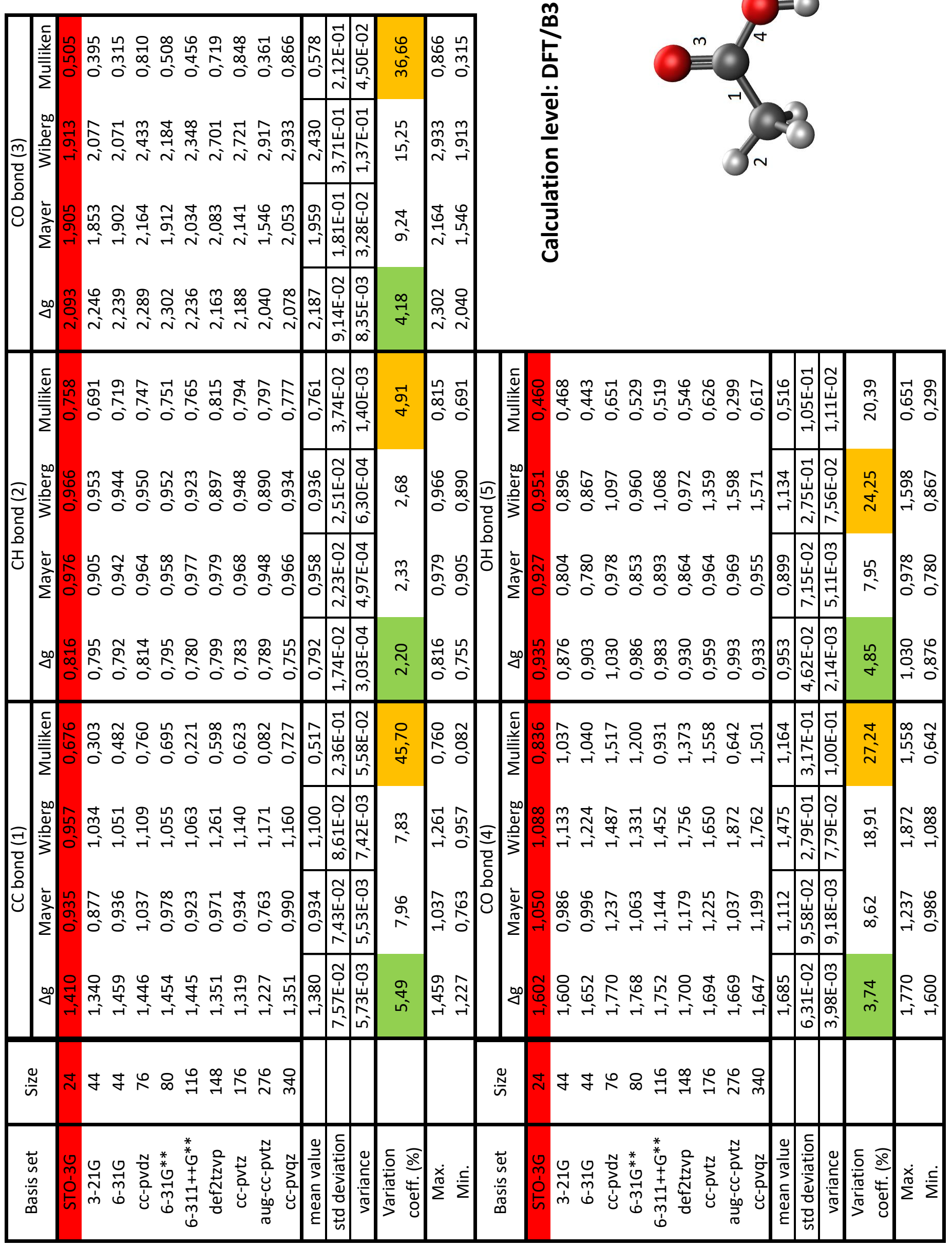




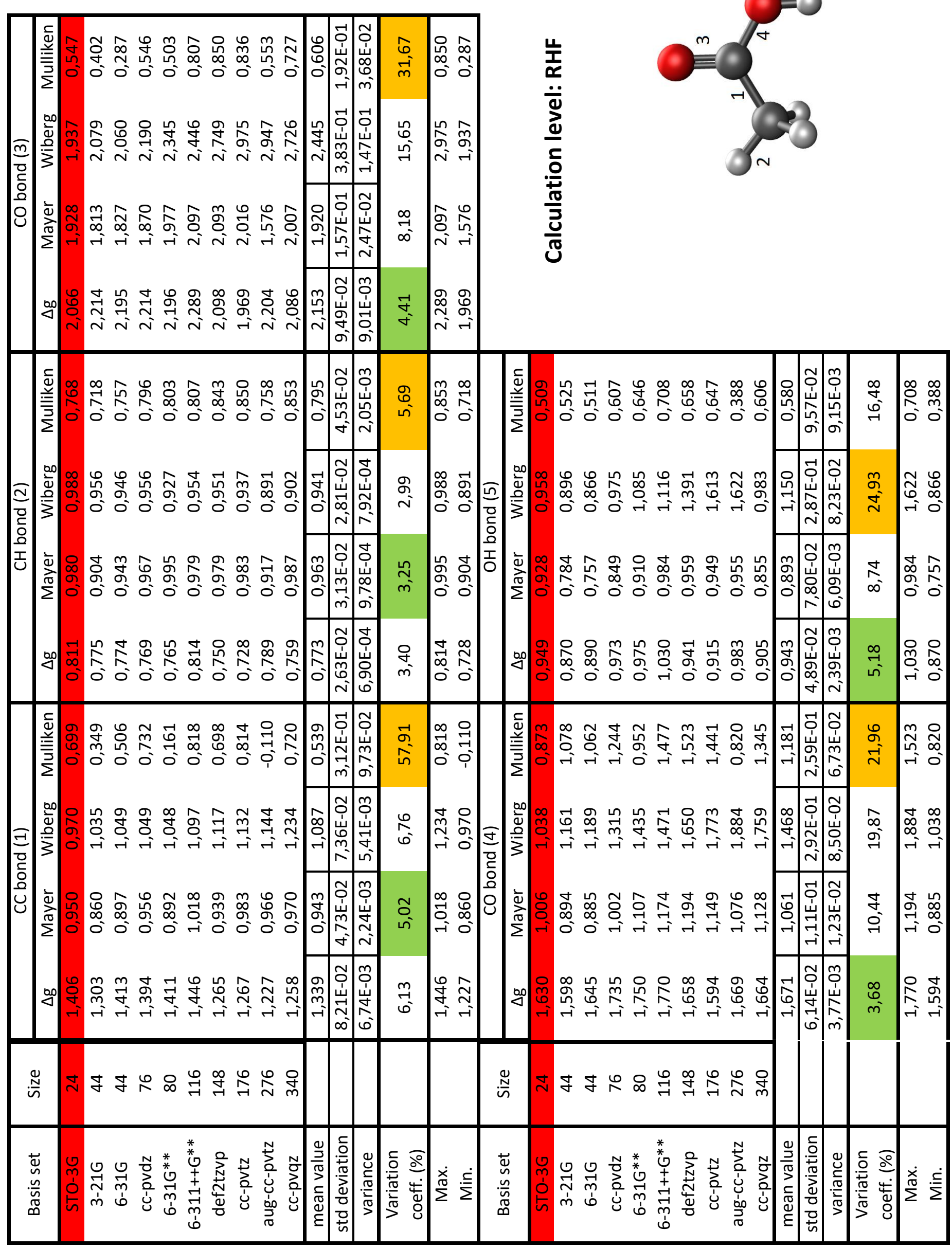




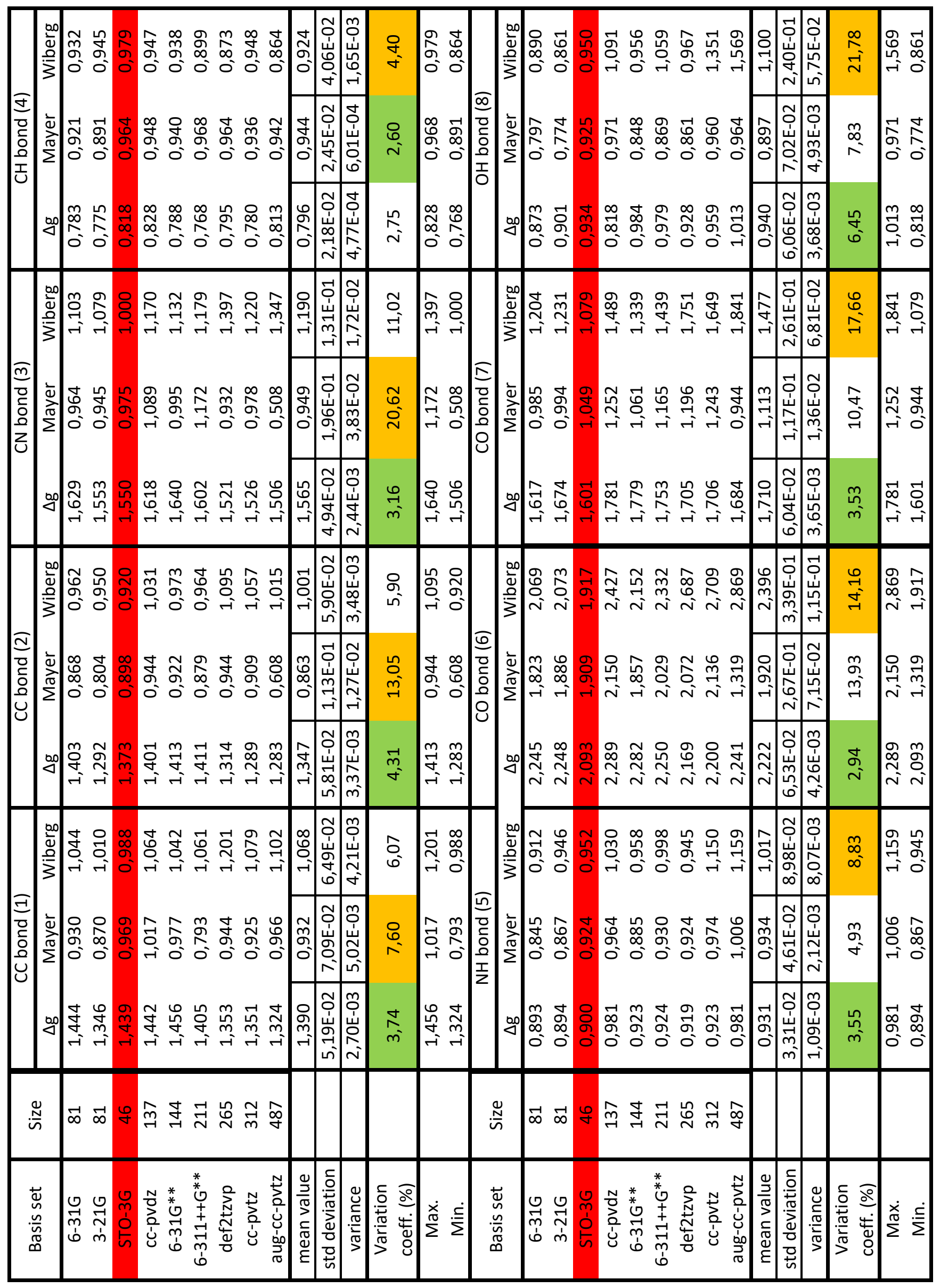




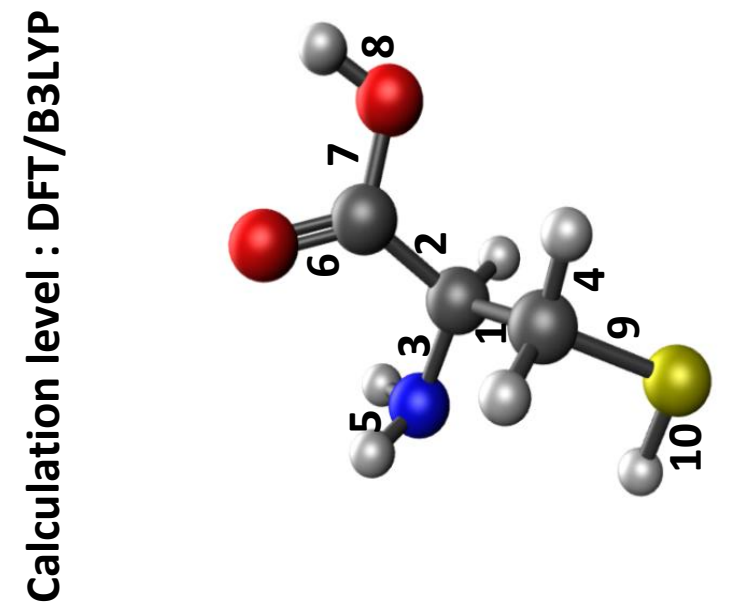

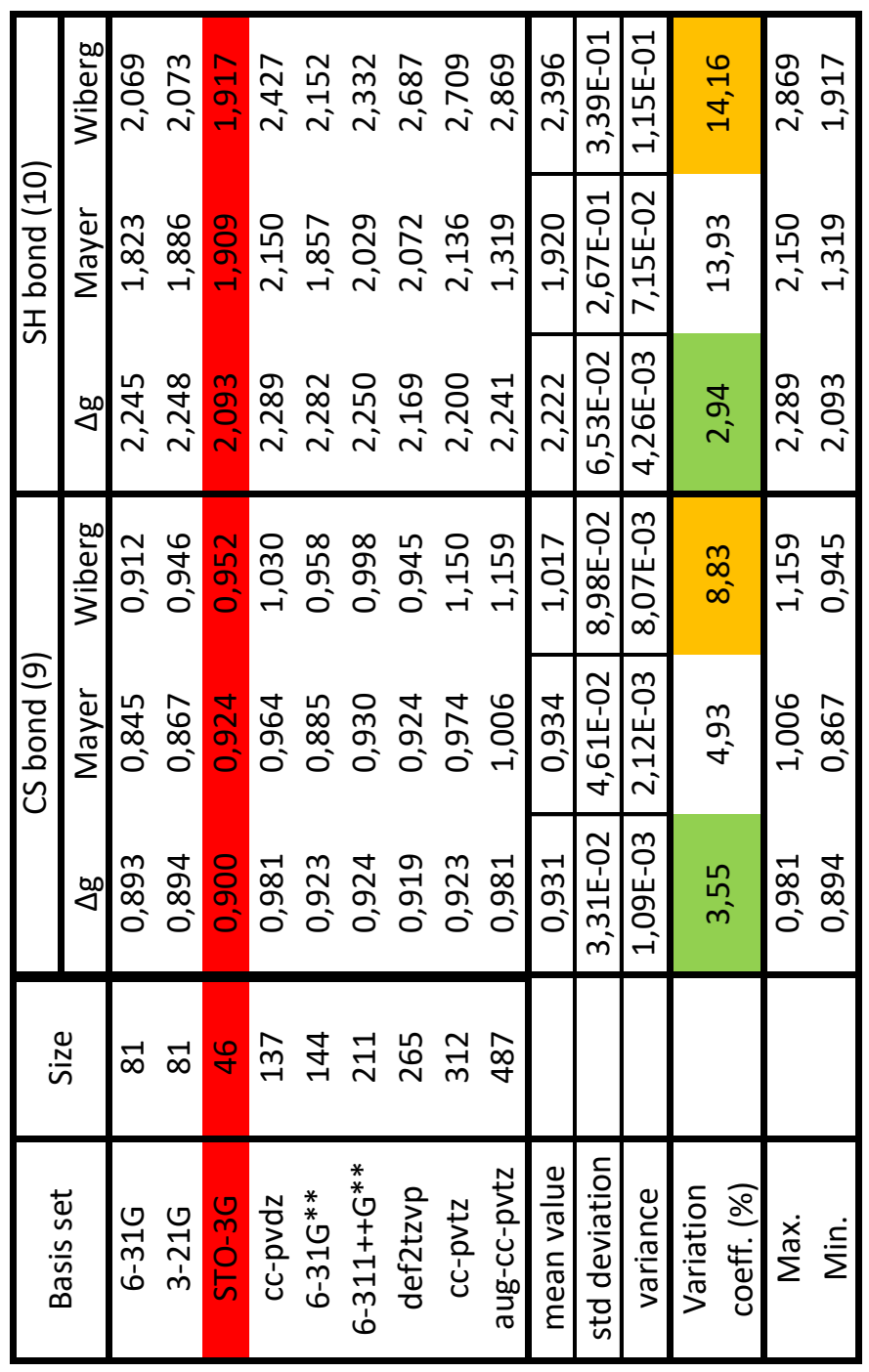




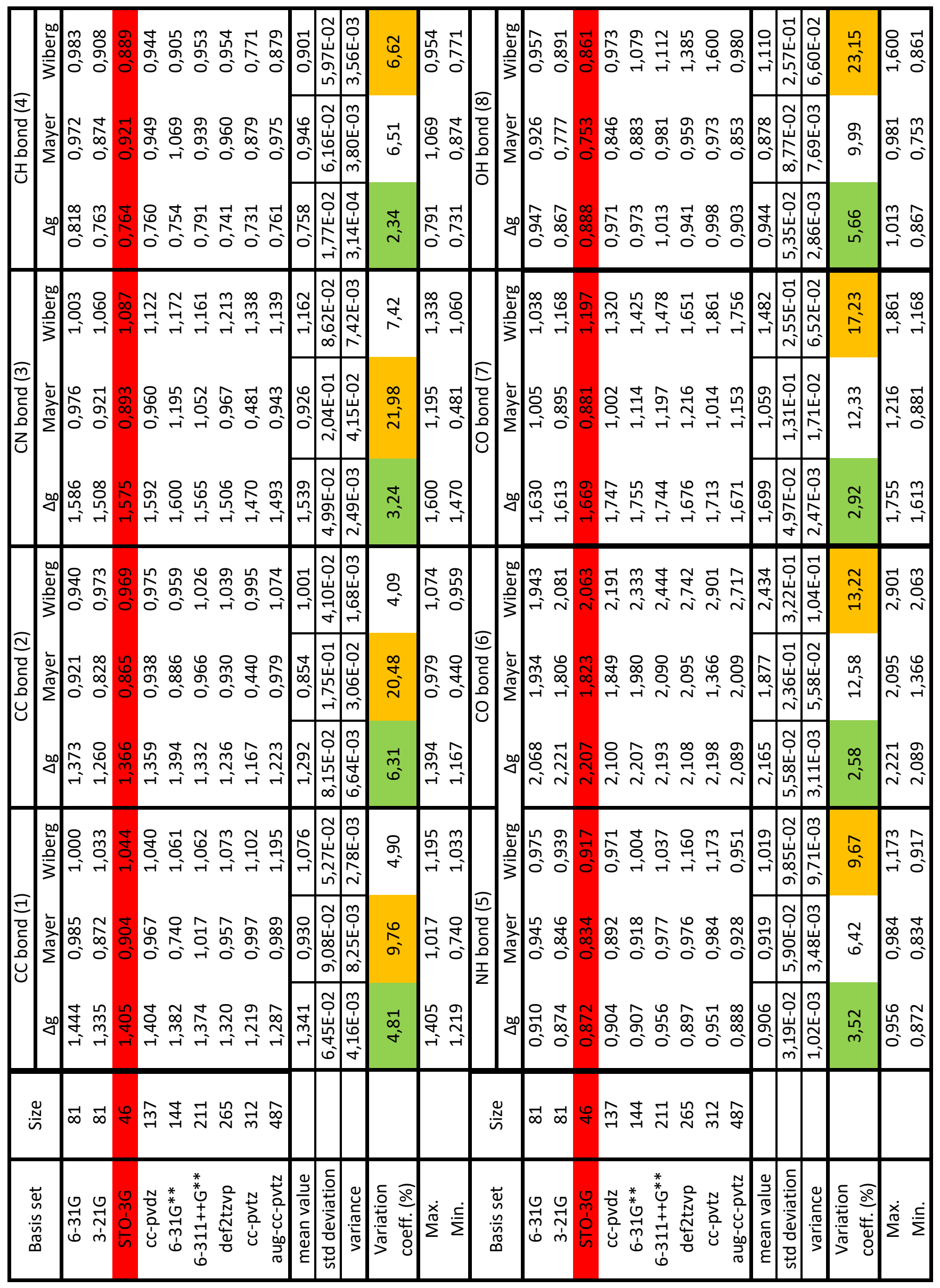




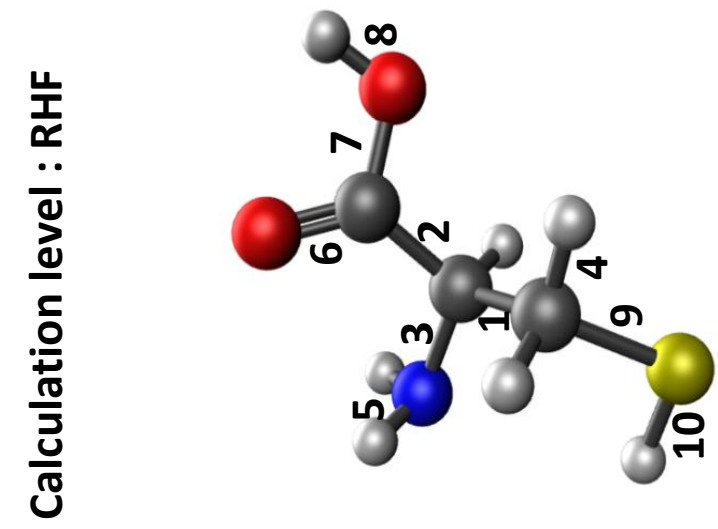

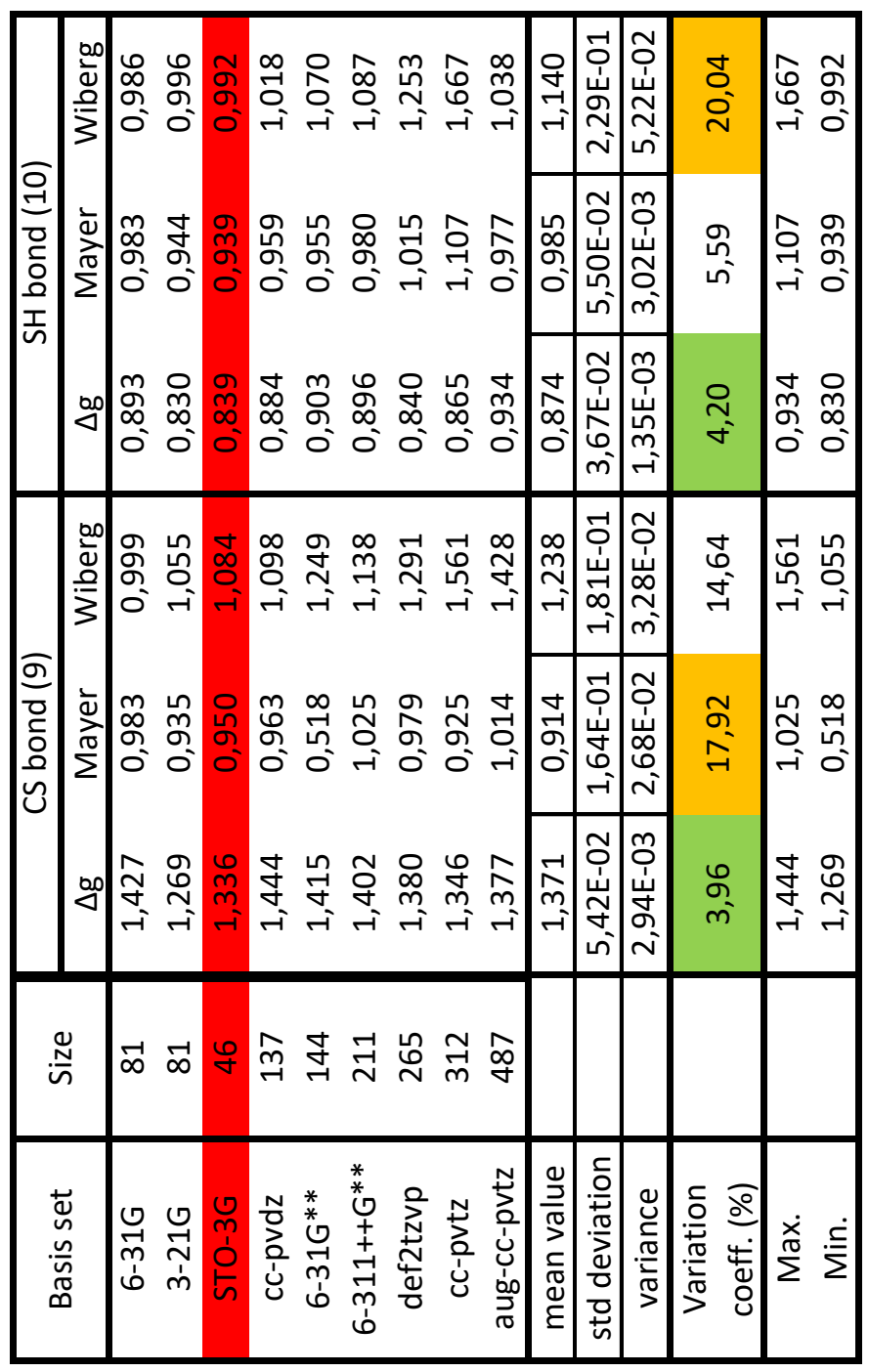



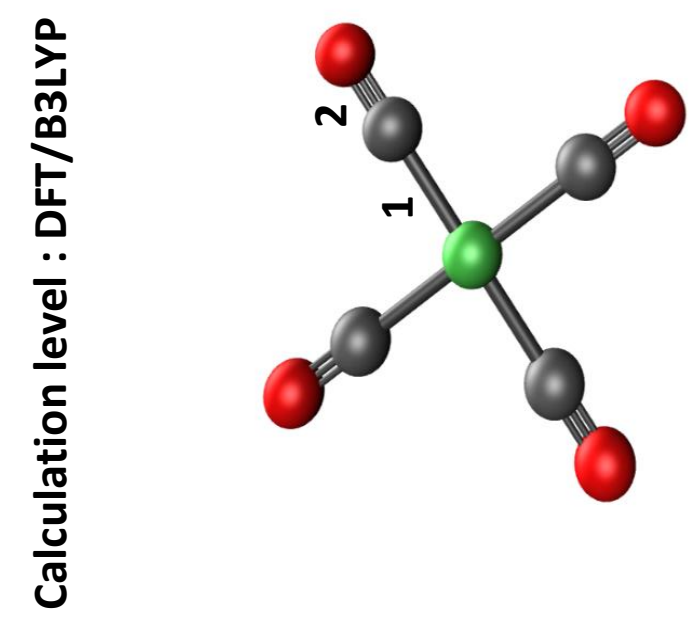

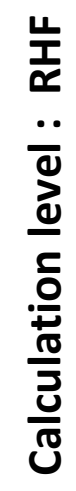

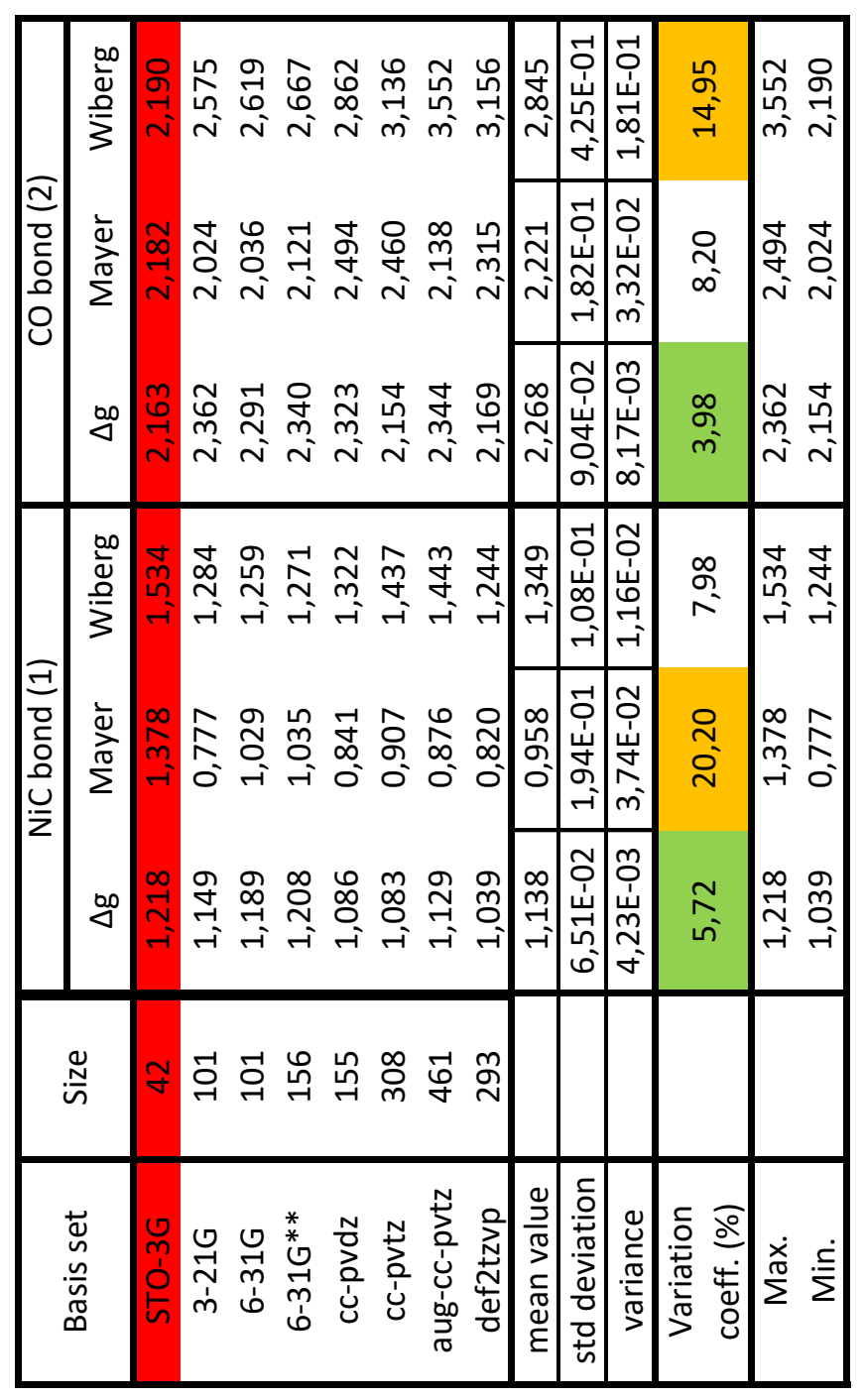

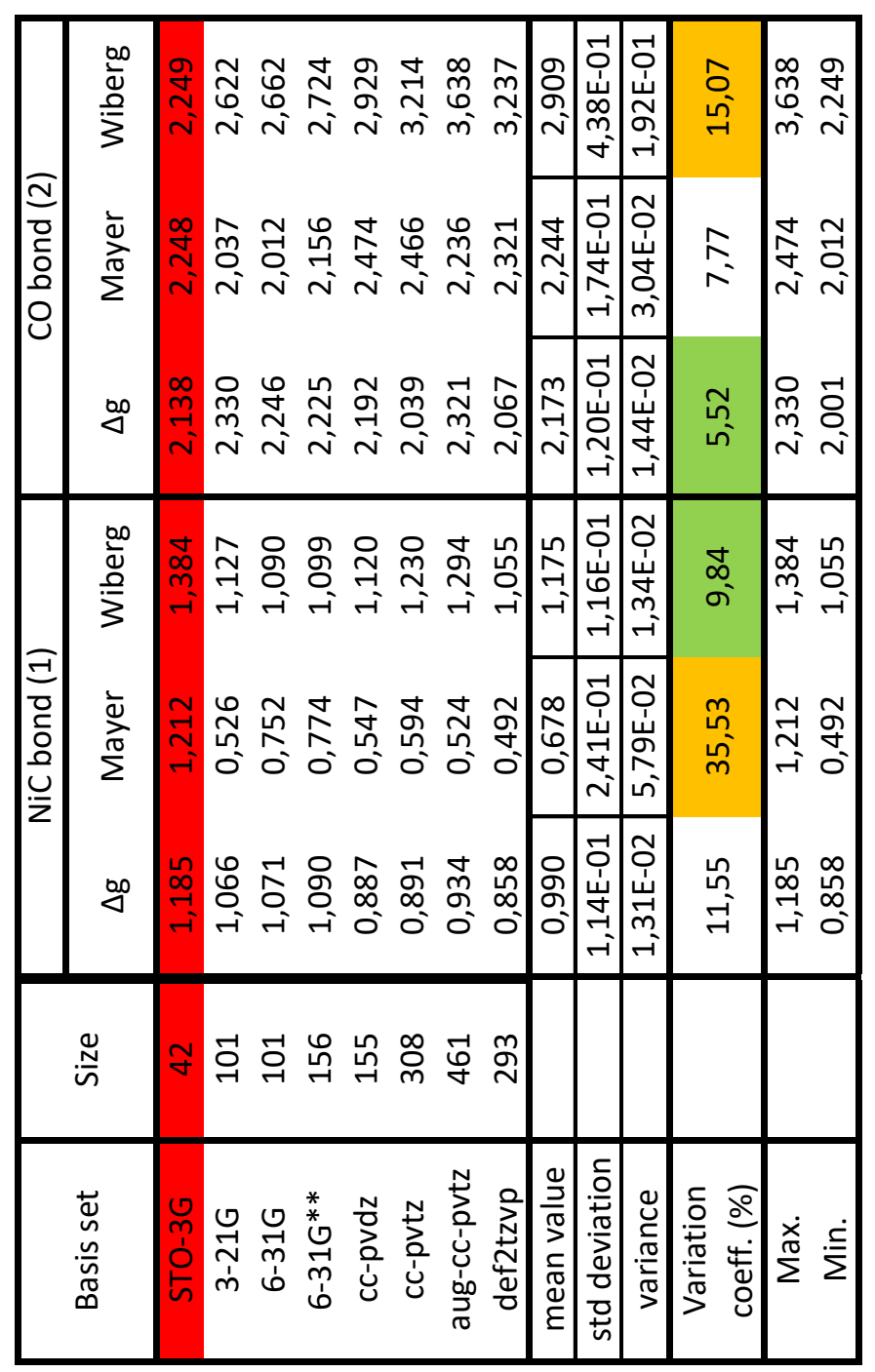




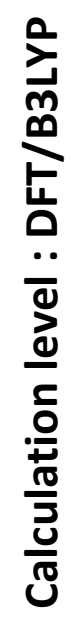$$
\begin{aligned}
& \frac{1}{1} \\
& \frac{1}{0} \\
& \frac{0}{0} \\
& \frac{1}{0} \\
& \frac{0}{\frac{\pi}{3}} \\
& \frac{0}{3}
\end{aligned}
$$

\begin{tabular}{|c|c|c|c|c|c|c|c|c|c|}
\hline 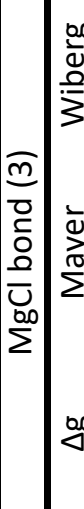 & 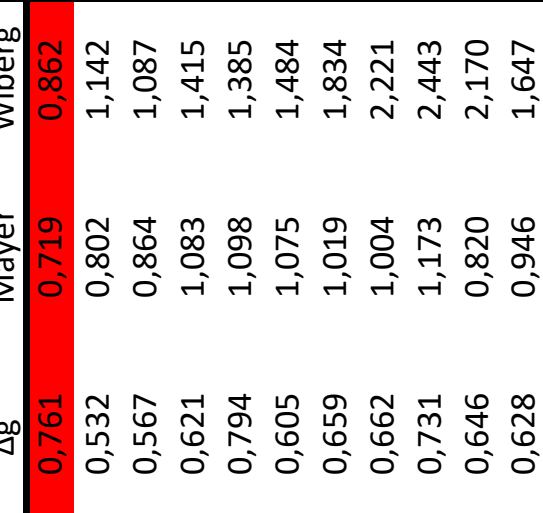 & 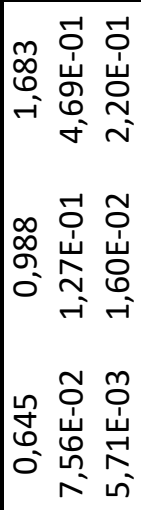 & $\stackrel{m}{\stackrel{n}{-}}$ & 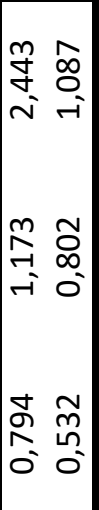 & & 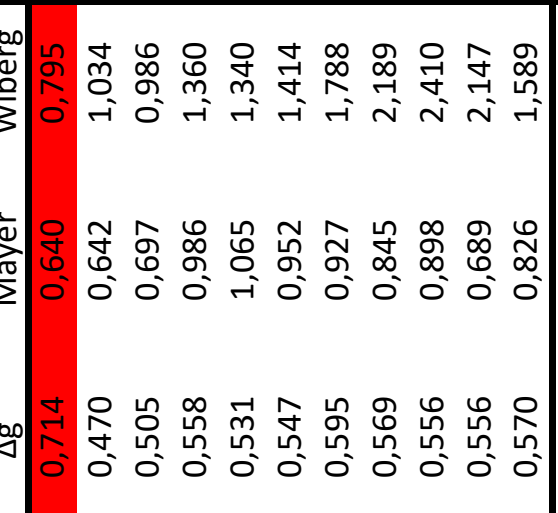 & 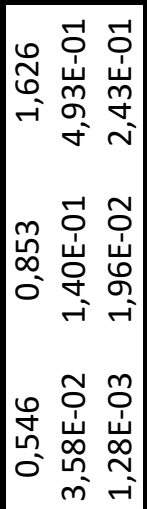 & $\begin{array}{l}\stackrel{J}{~} \\
\stackrel{\sigma}{-}\end{array}$ & 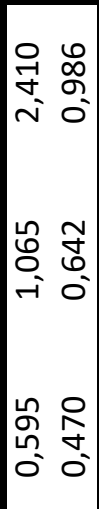 \\
\hline 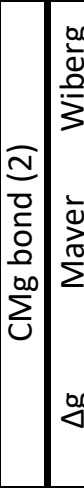 & 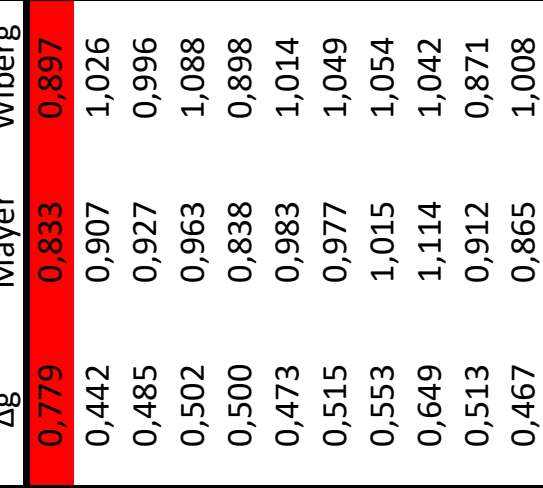 & 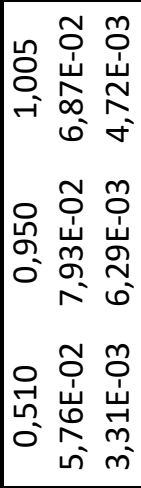 & $\begin{array}{l}\stackrel{\text { I }}{-} \\
\text { - }\end{array}$ & 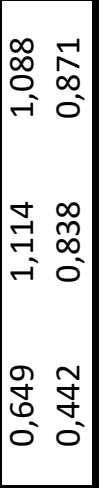 & 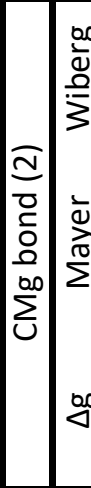 & 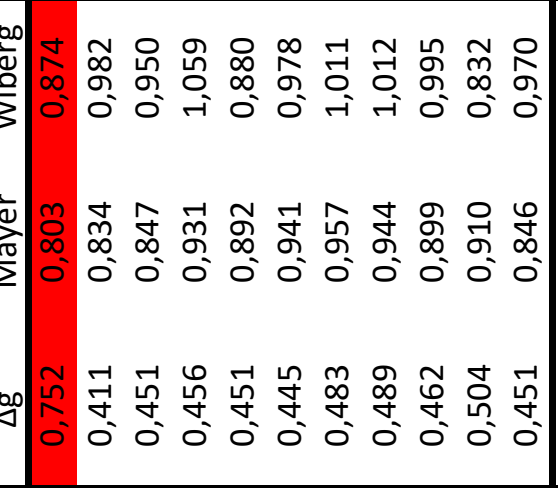 & 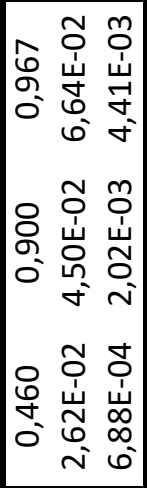 & $\begin{array}{l}\stackrel{?}{r} \\
\text { in }\end{array}$ & 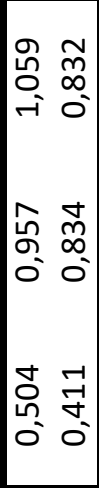 \\
\hline 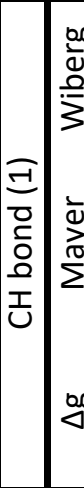 & 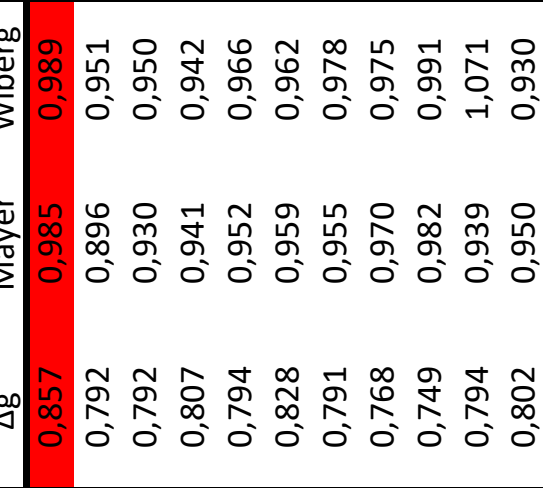 & 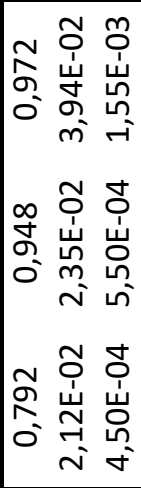 & $\underset{\infty}{\infty}$ & 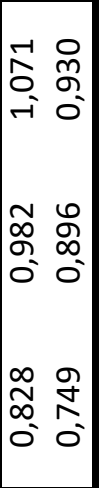 & 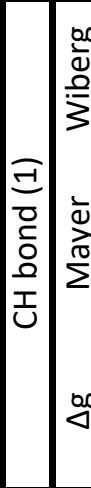 & 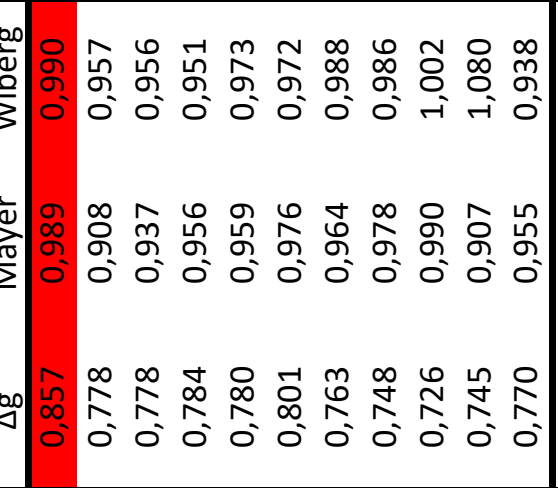 & 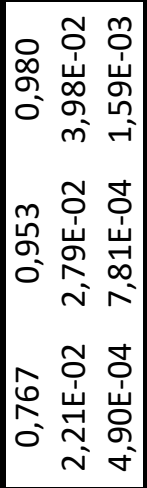 & 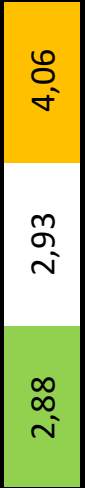 & 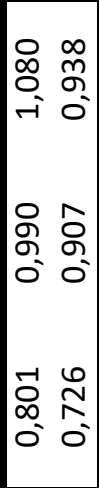 \\
\hline$\stackrel{N}{N}$ & 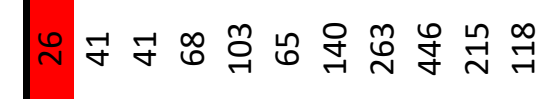 & & & & $\stackrel{N}{n}$ & & & & \\
\hline $\begin{array}{l}\stackrel{4}{\nu} \\
心 \\
\frac{n}{n} \\
\tilde{D} \\
\infty\end{array}$ & 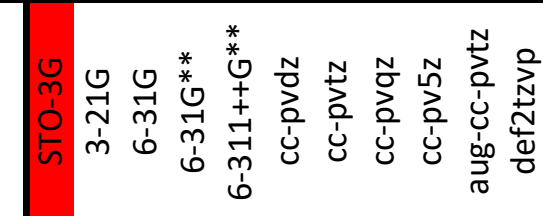 & 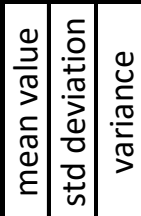 & 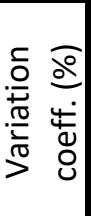 & $\sum_{\substack{x \\
\dot{\infty}}}^{\dot{\Sigma}} \dot{\Sigma}$ & 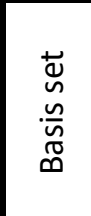 & 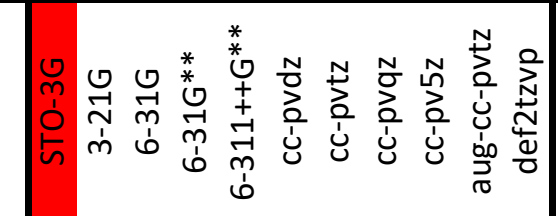 & 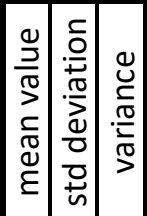 & 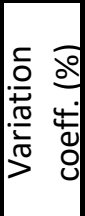 & $\underset{\dot{x}}{\stackrel{x}{\pi}}$ \\
\hline
\end{tabular}



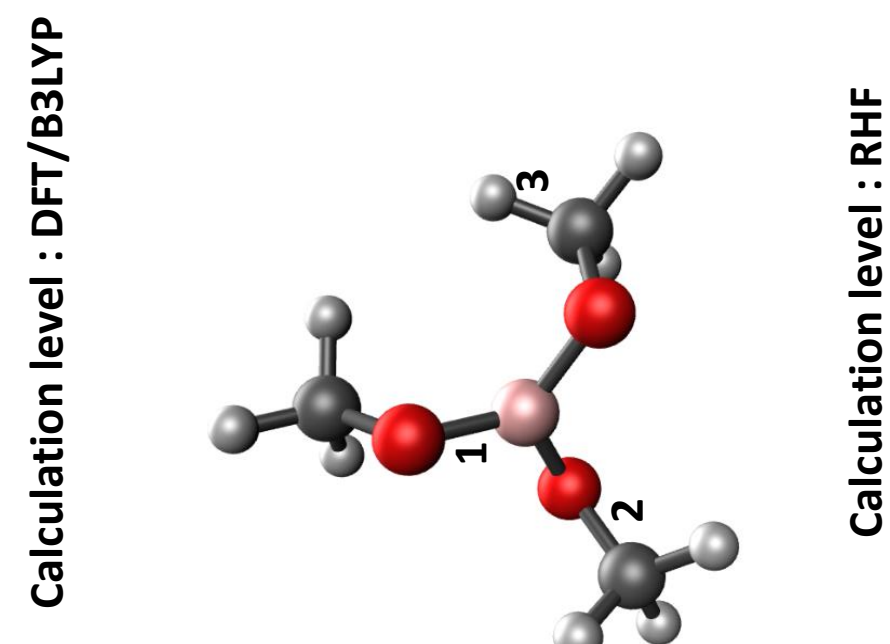

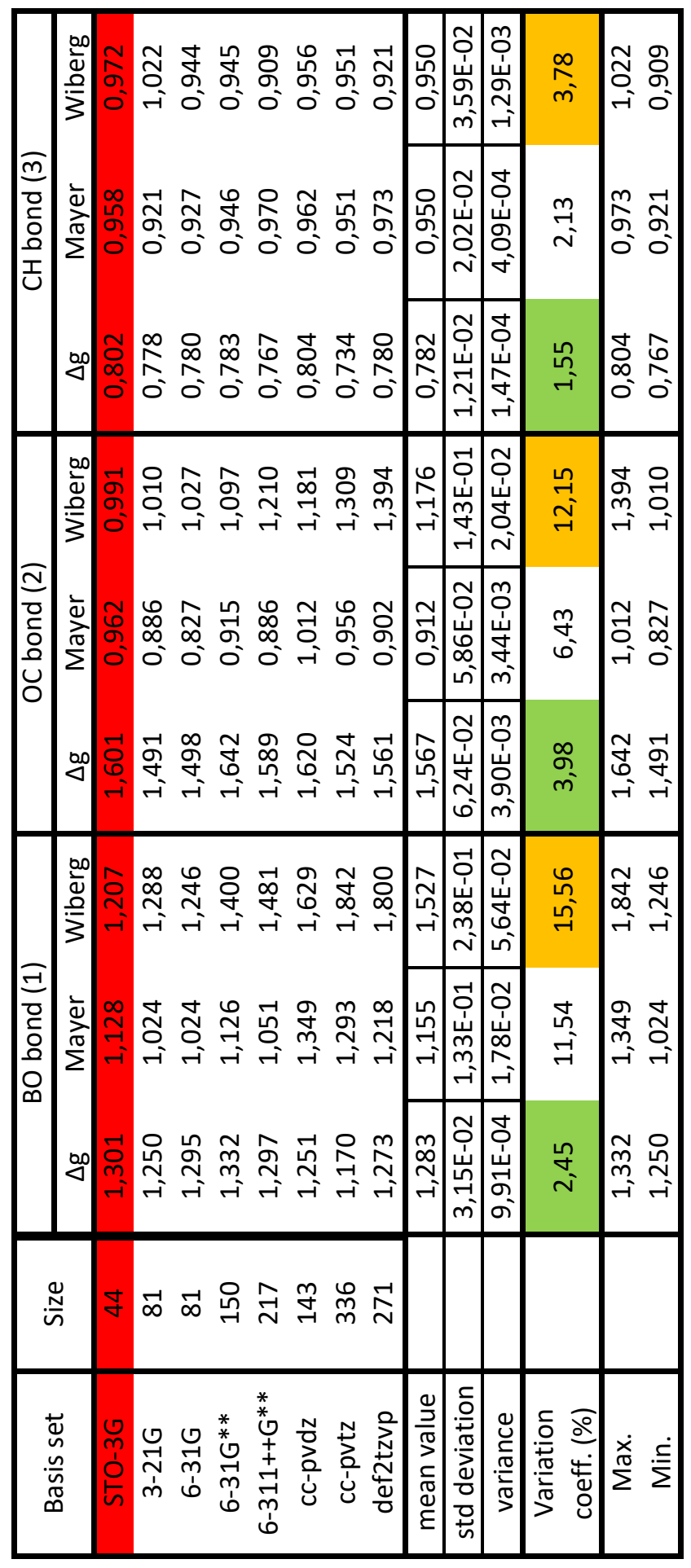

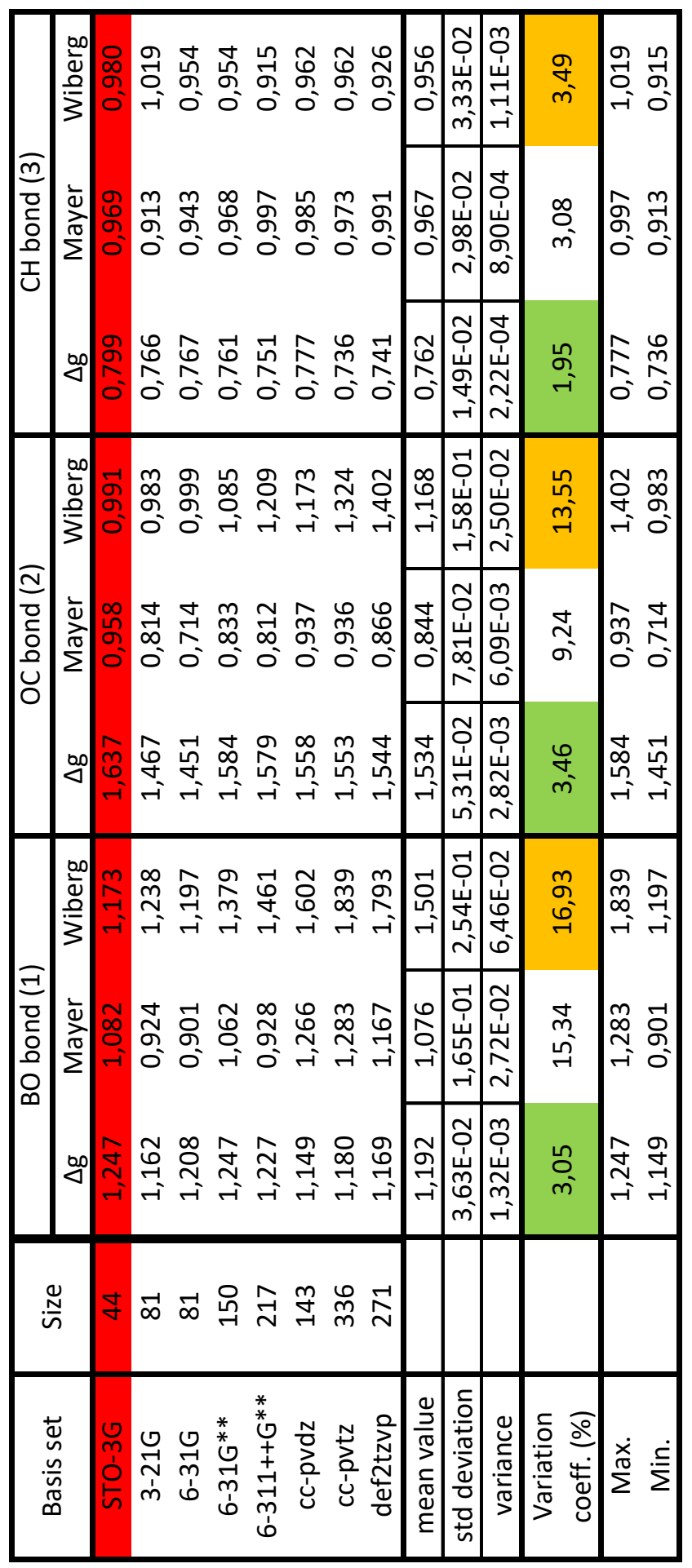




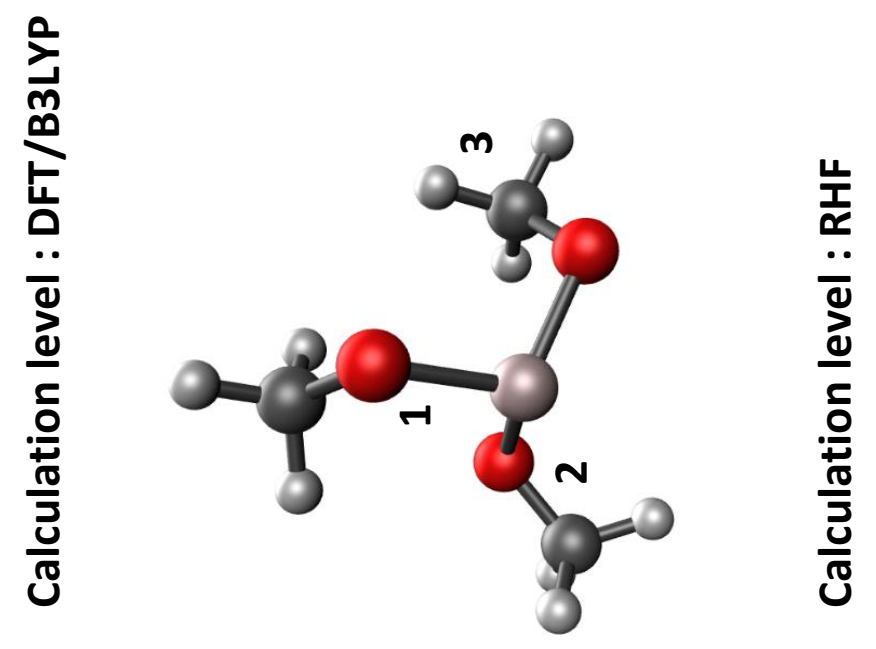

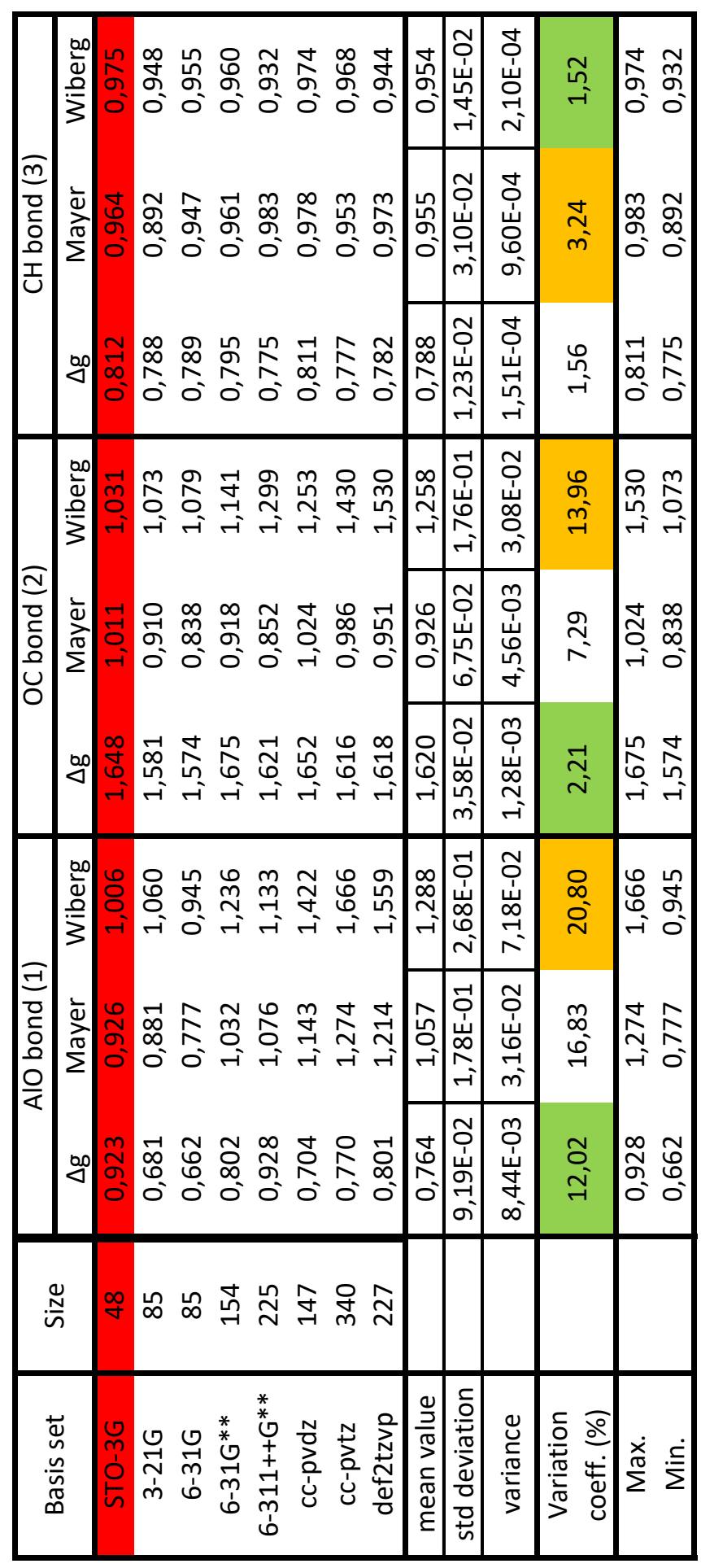

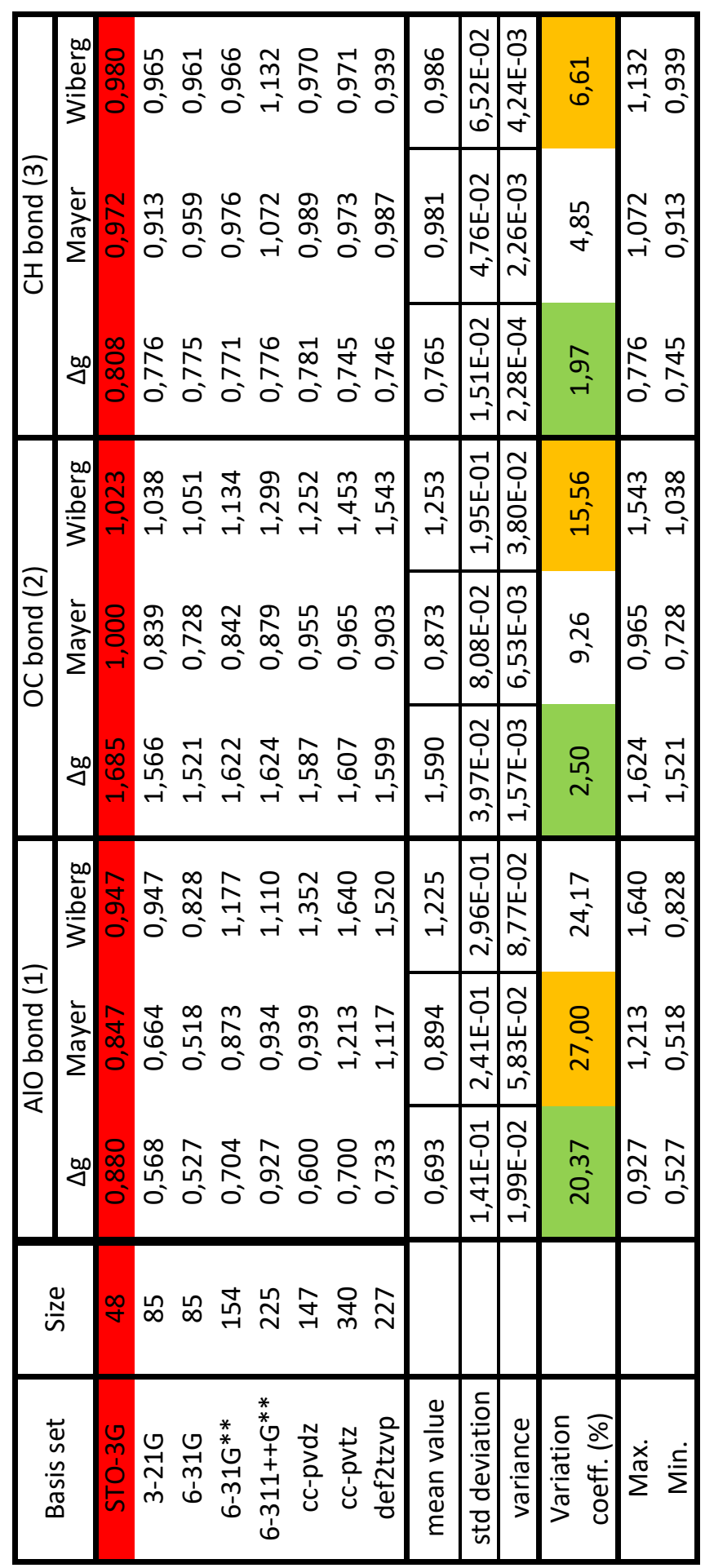




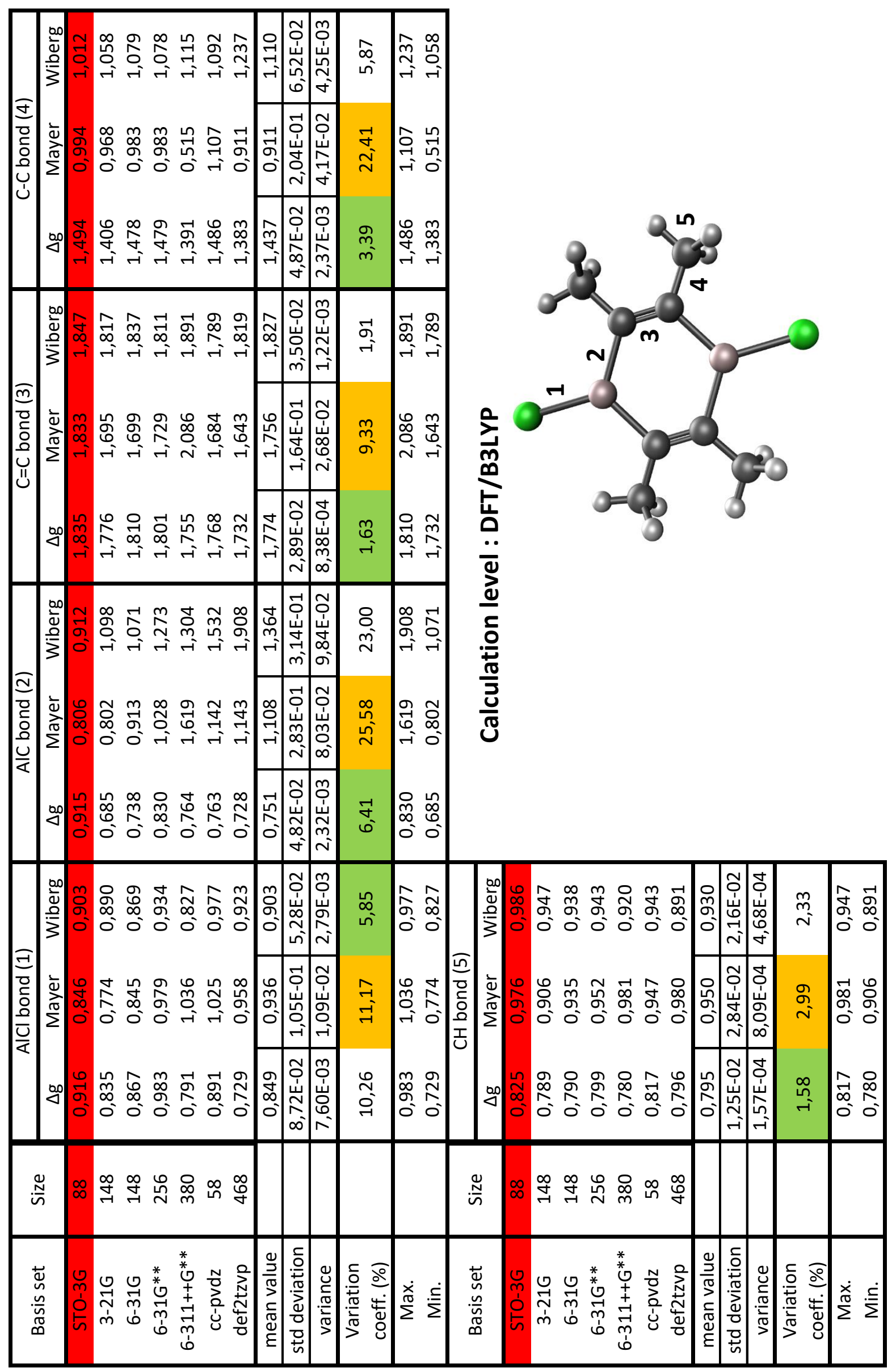



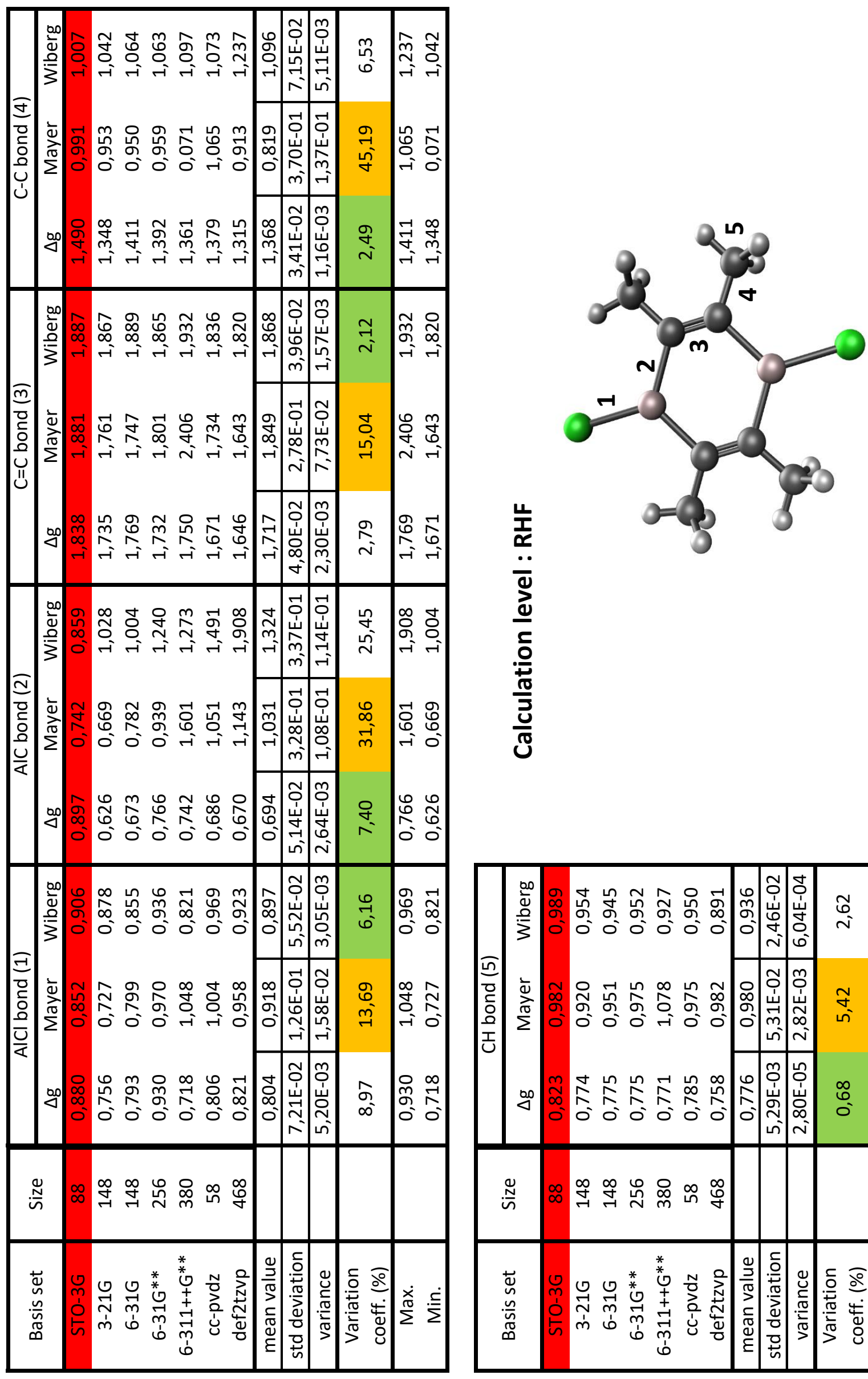

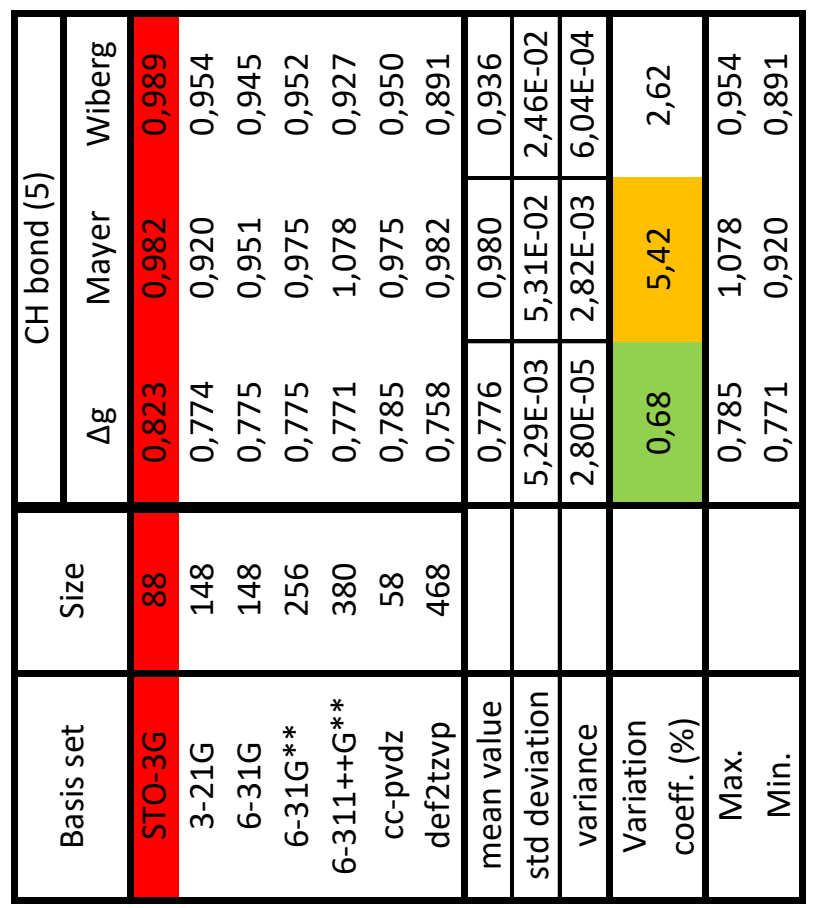




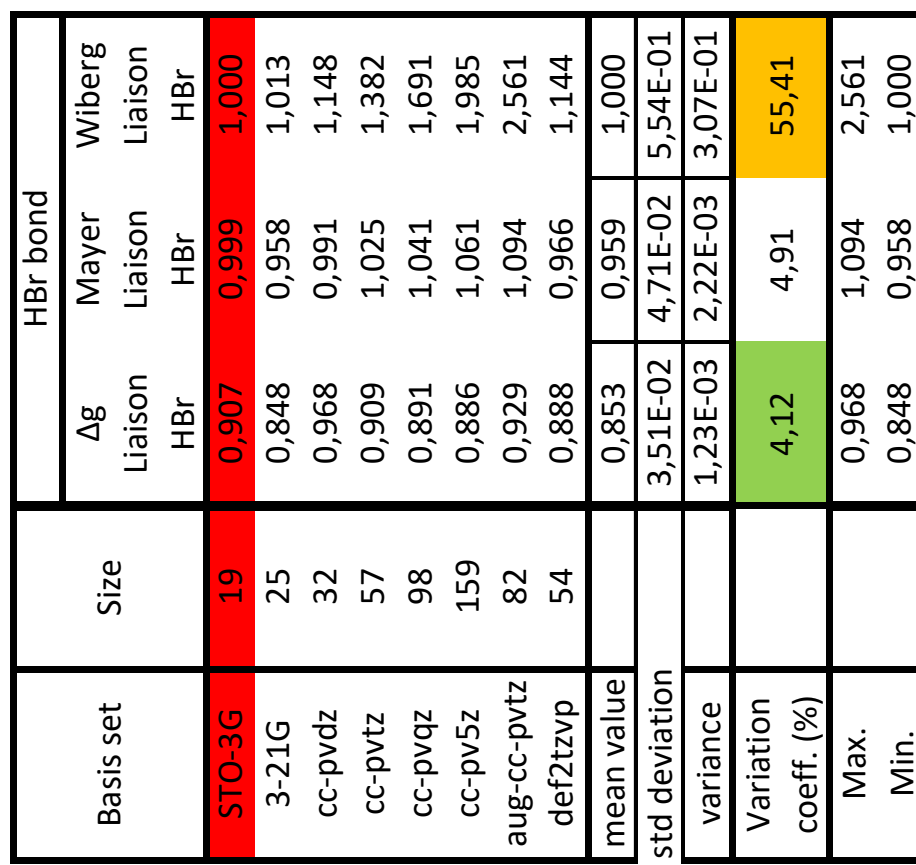

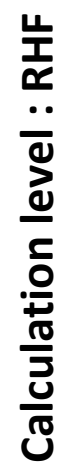

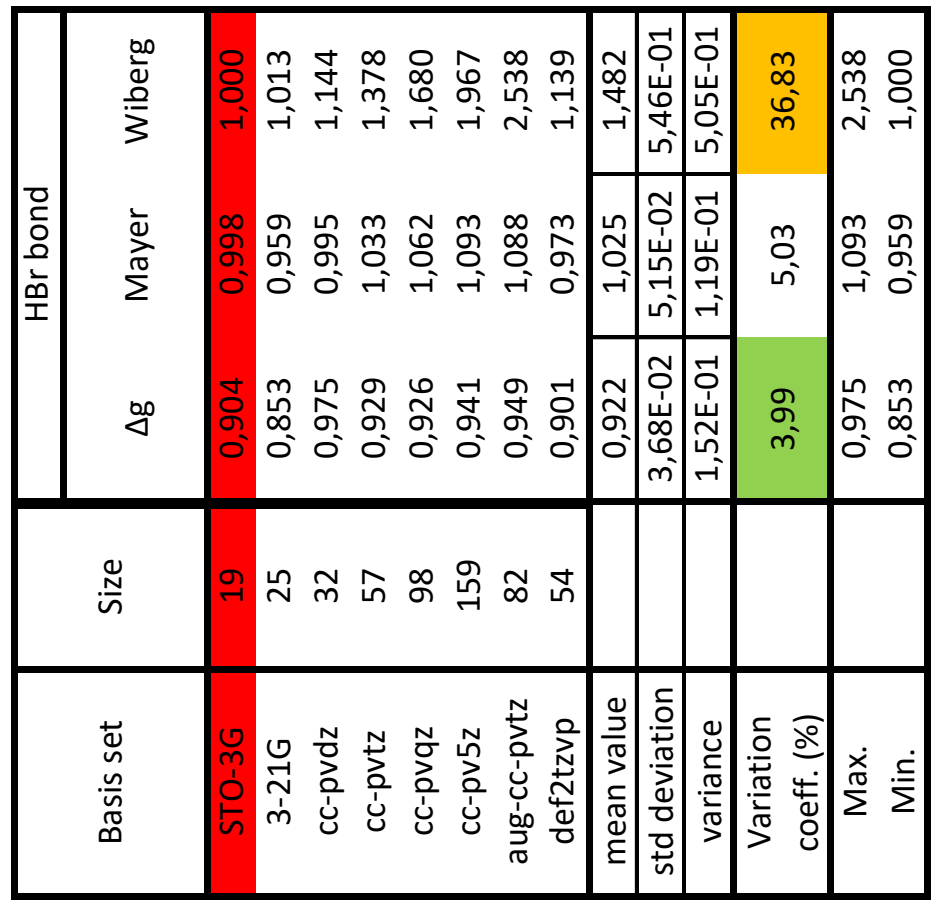

竞 


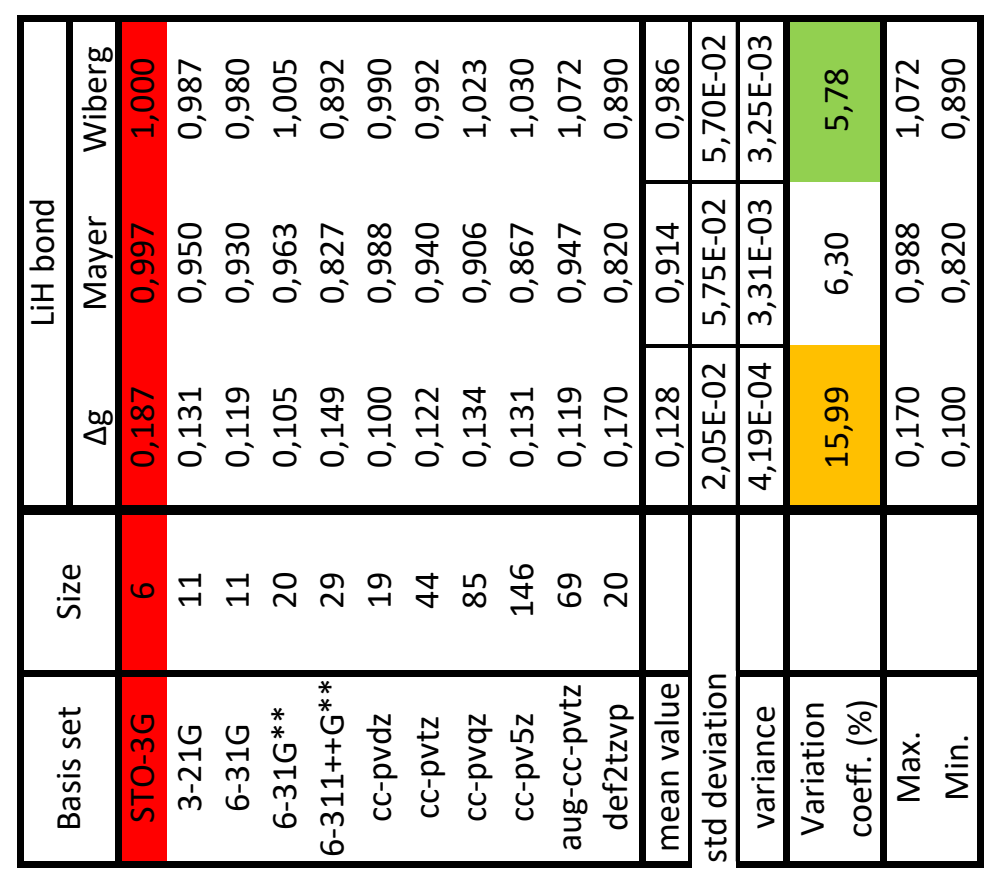

$\frac{1}{x}$
$\frac{1}{0}$
$\frac{0}{3}$
$\frac{}{0}$
$\frac{0}{\frac{0}{3}}$
$\frac{0}{0}$

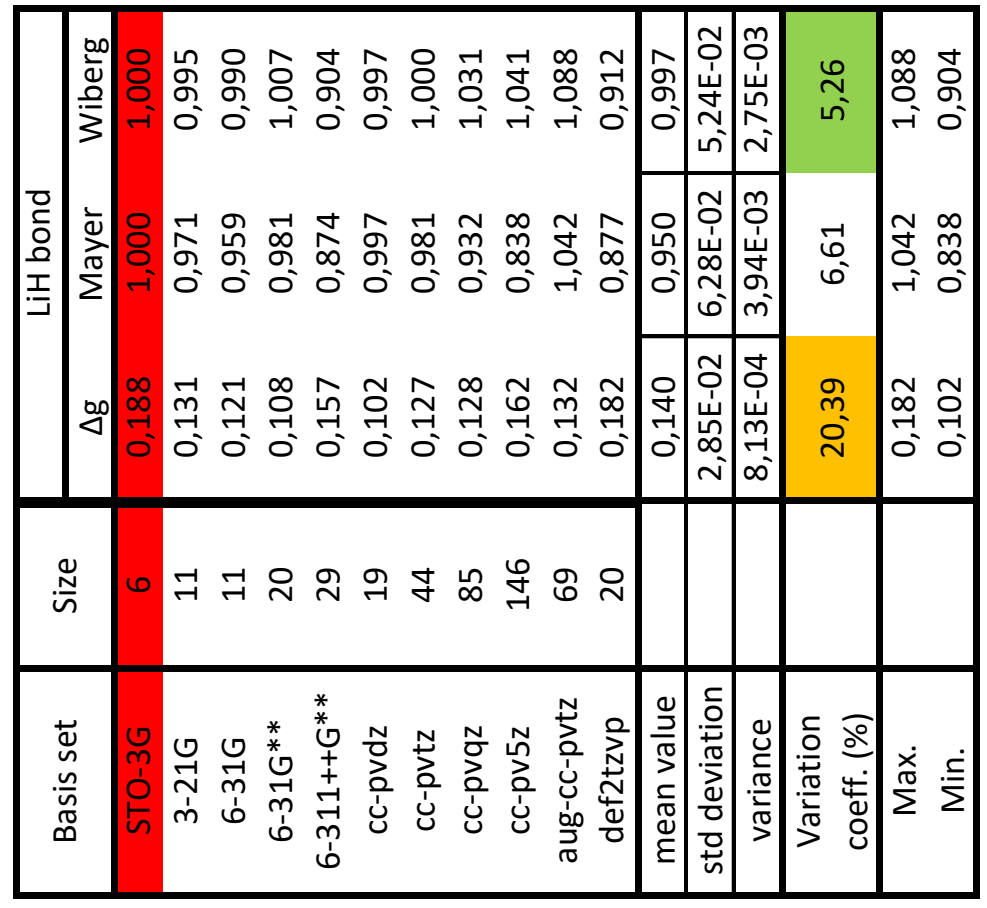

菅 


\section{Influence of quantum mechanical method on the value of $\Delta g$}

Similarly, case studies have been carried out to address the influence of the method on the value of $\Delta g^{\text {pair }}$. The HF method, 4 DFT functionals together with the MP2 method have been considered for the 9 molecules above-mentioned, covering single- and multi-determinent approaches. The value of $\Delta g^{\text {pair }}$ is shown to be hardly dependent on the level of theory. For each test, the worst result (furthest away from the $\Delta g^{\text {pair }}$ average) is indicated with a red line. Subsequent calculations have been performed, as far as possible, using the M06-2X DFT functional and the 6-31G** basis set. We advise using methods beyond the HF level of theory. 


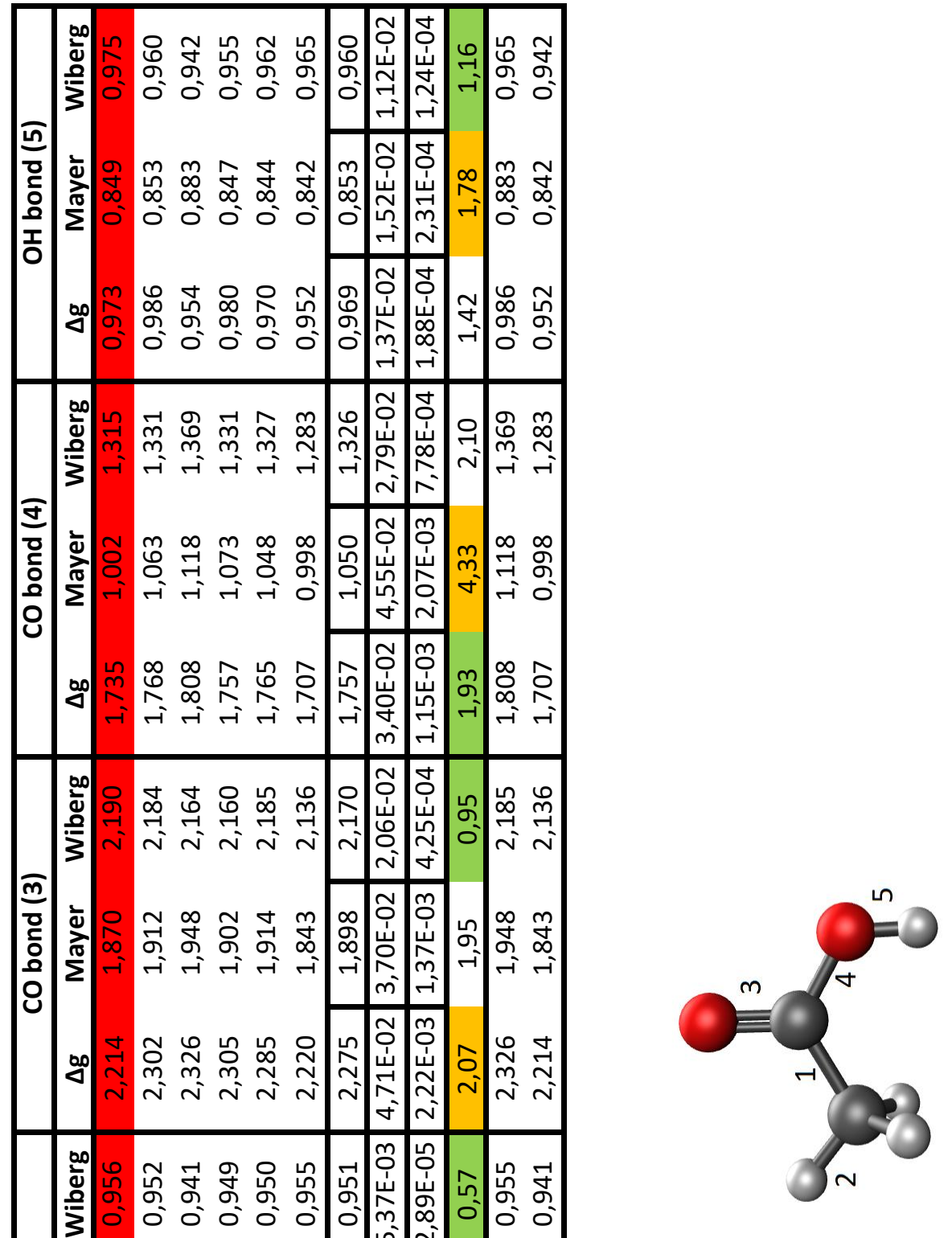




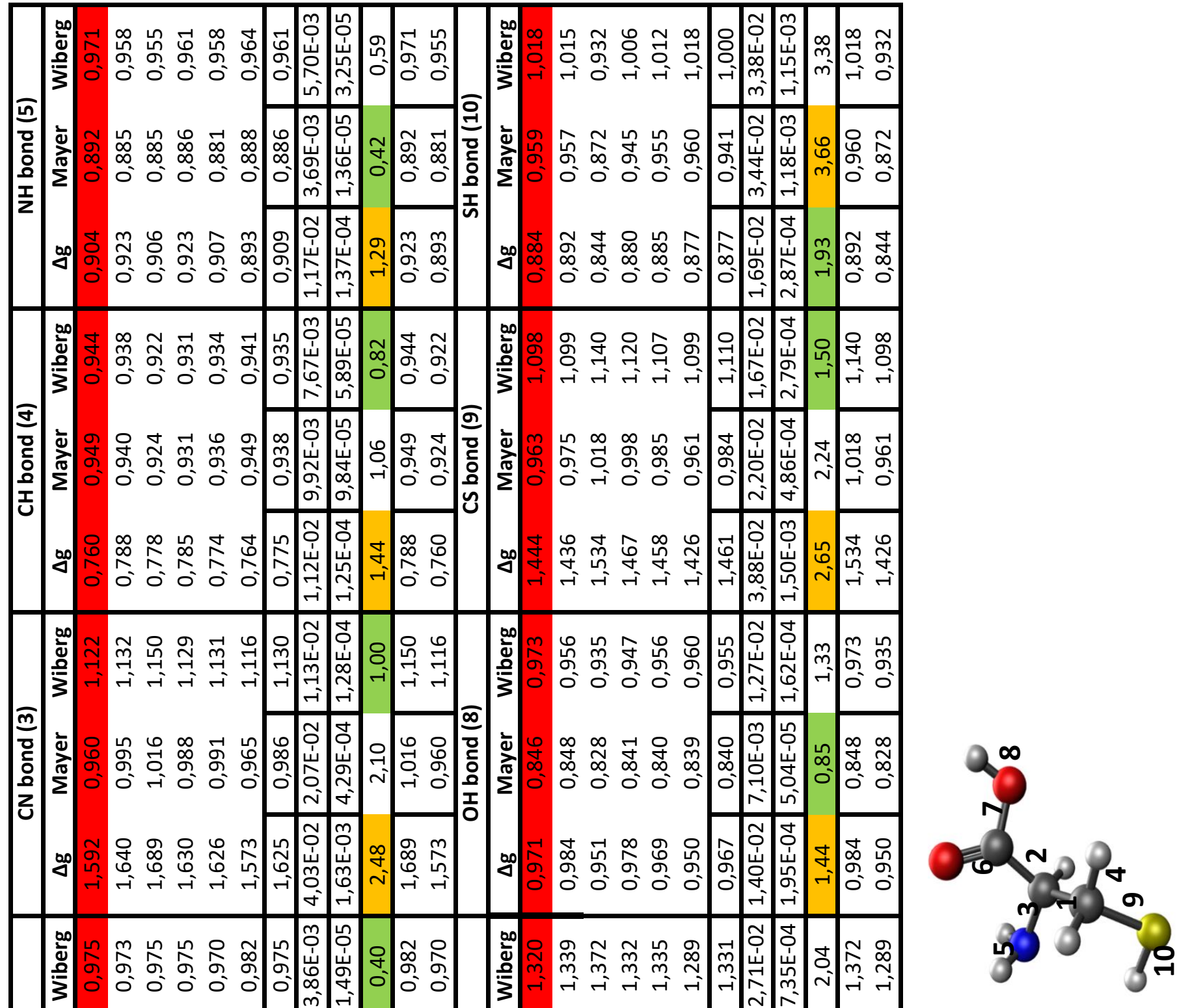

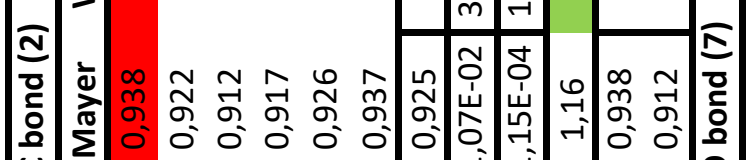

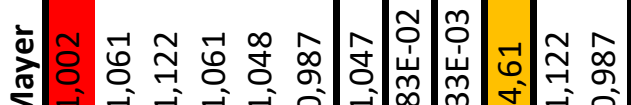
ư

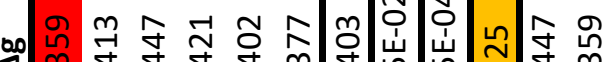

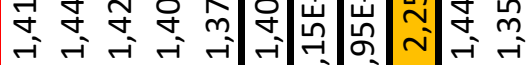

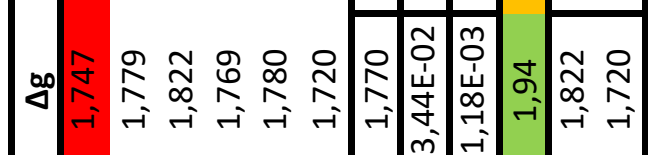

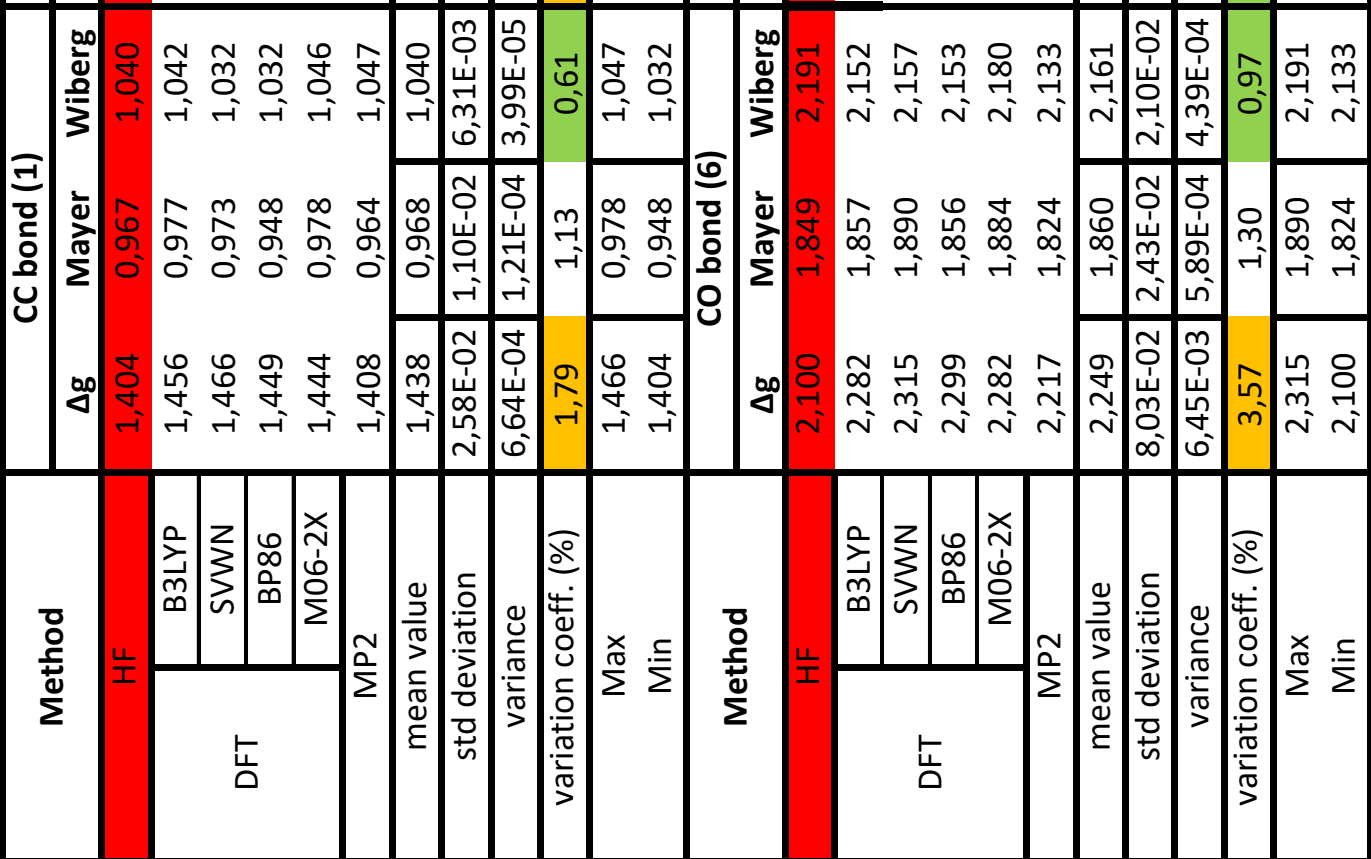

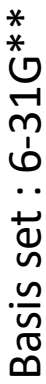


$*$
$*$
0
$n$
0
0
$\cdots$
+
0
$n$
$n$
$\frac{n}{n}$
0
0

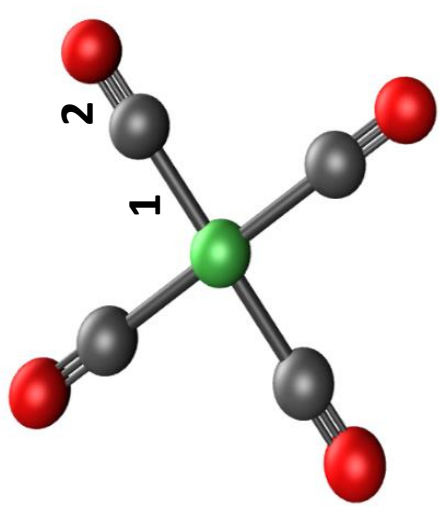

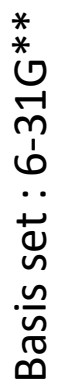
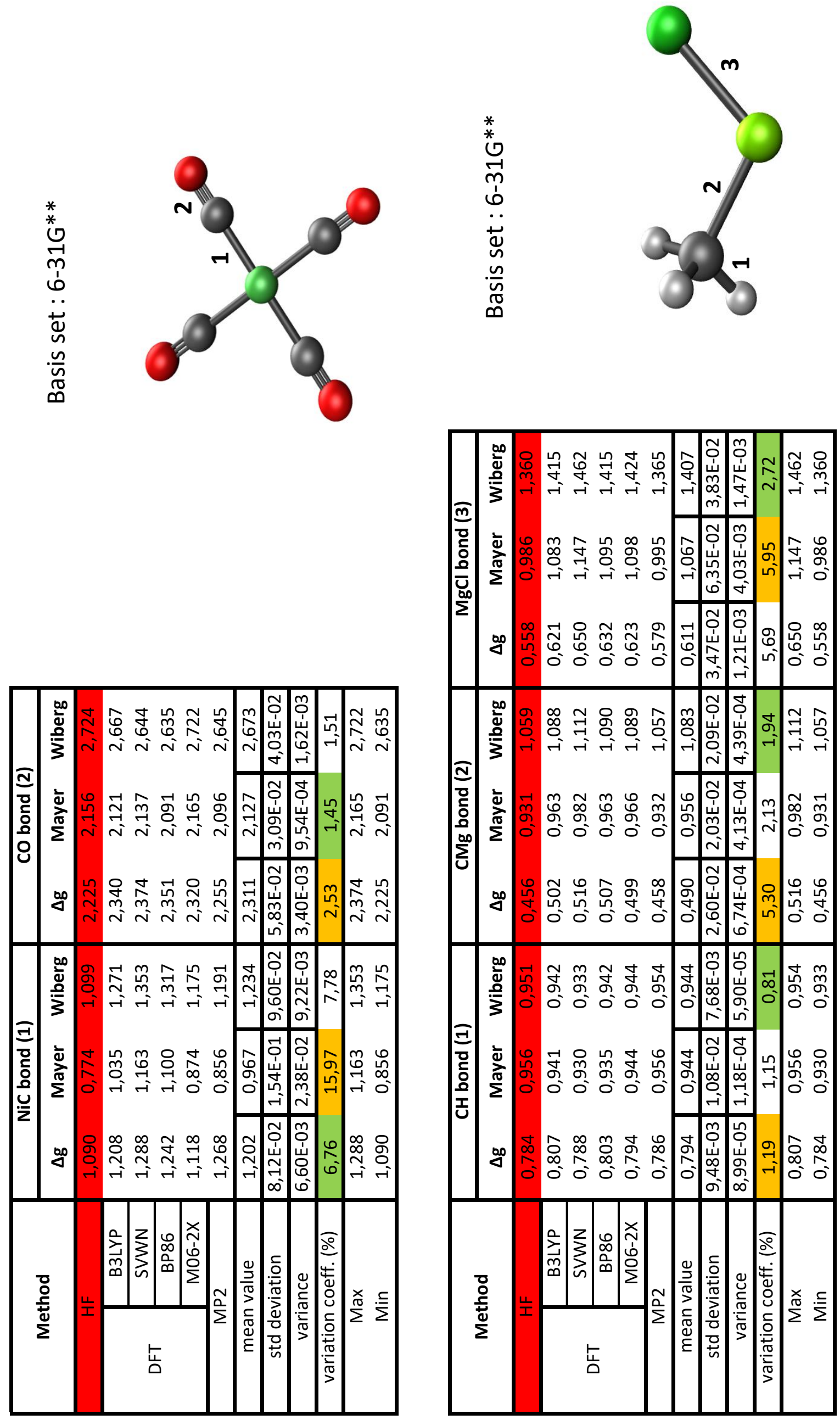

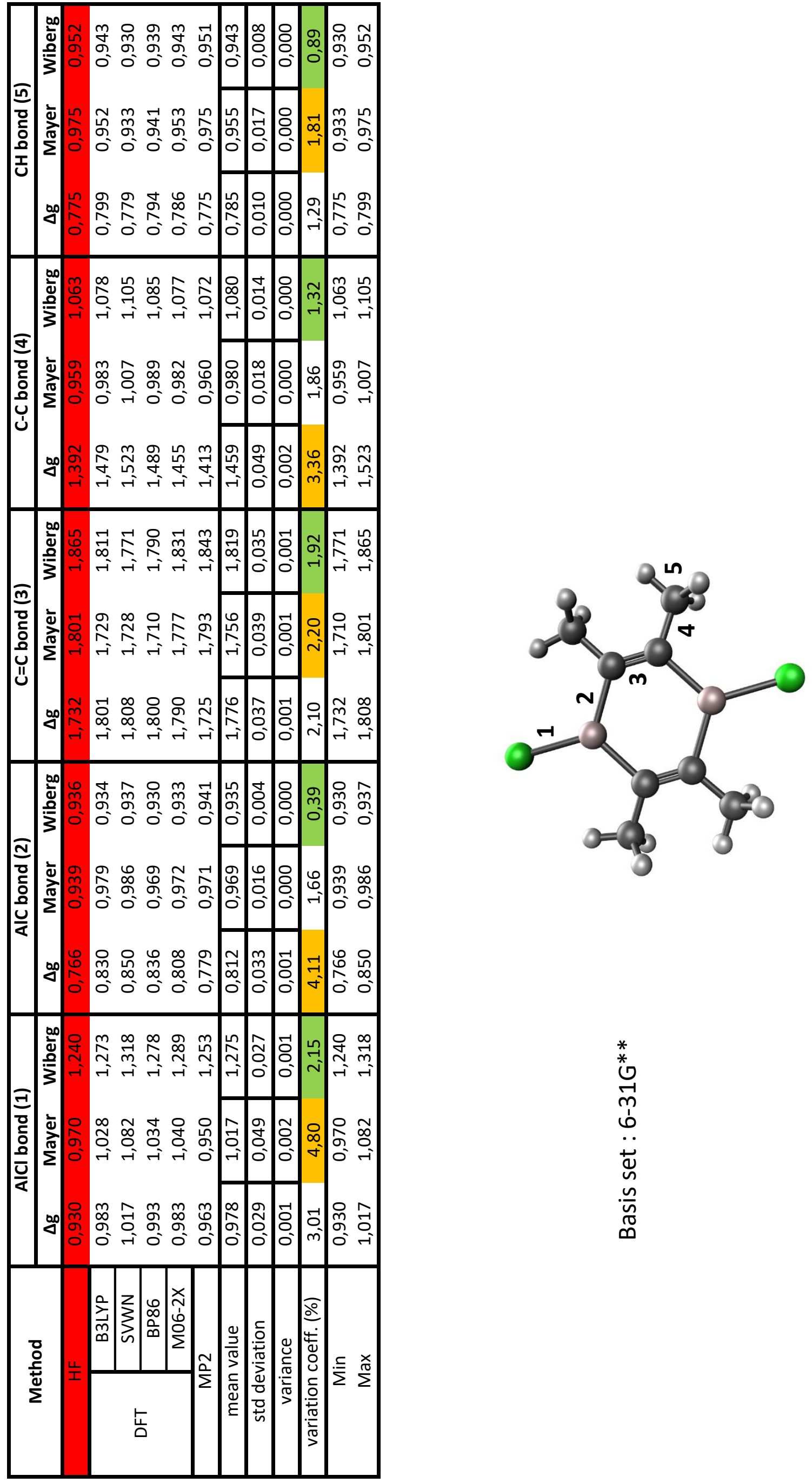

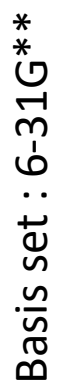



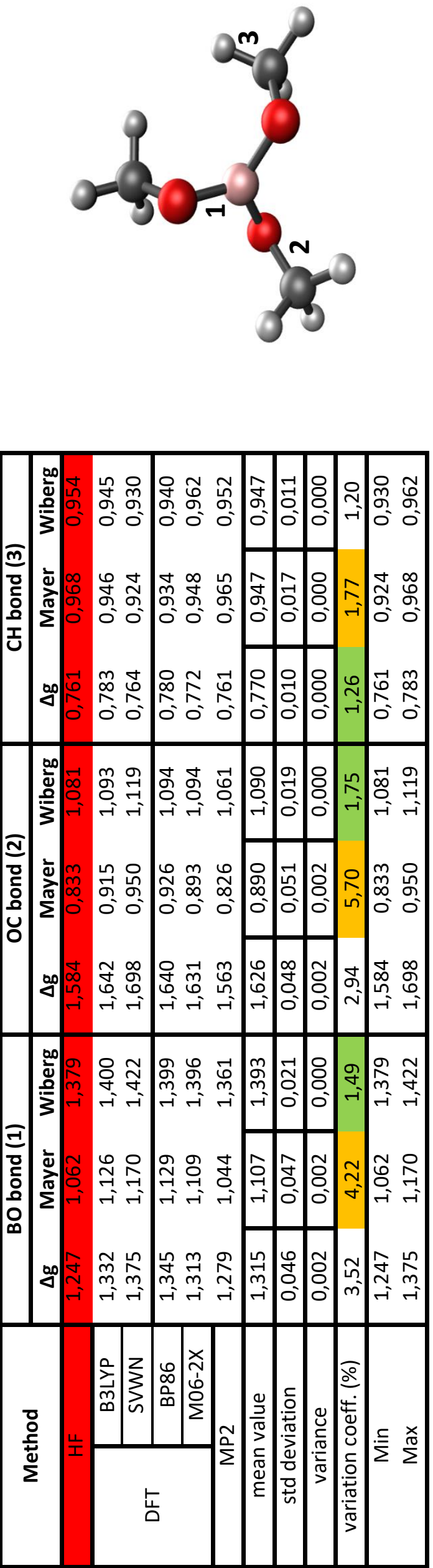

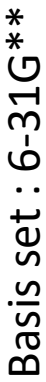
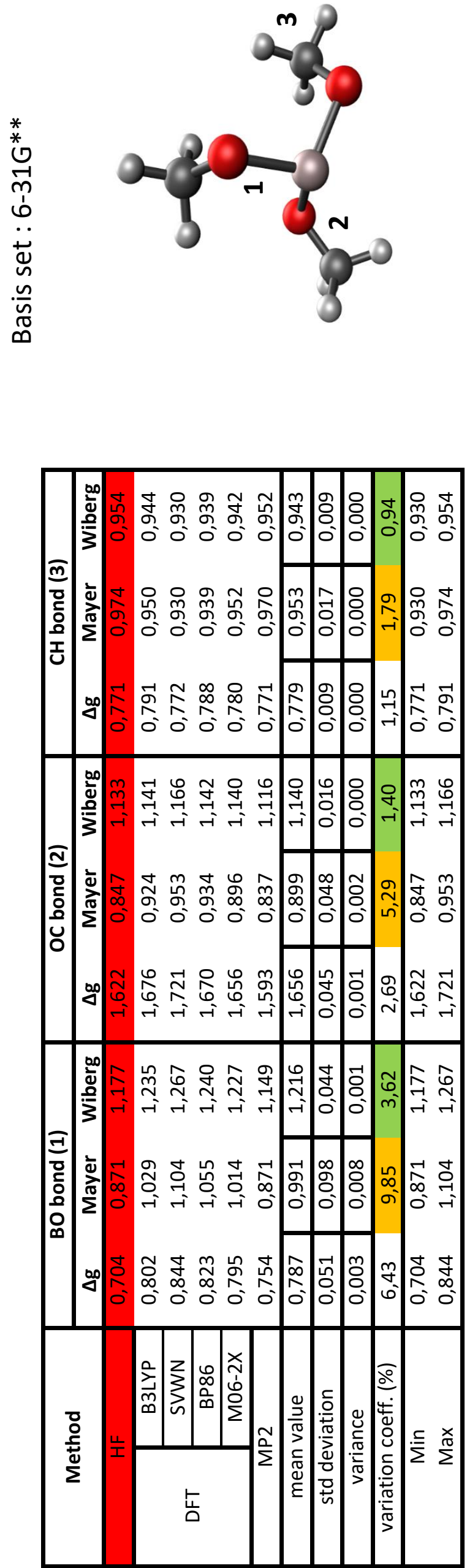

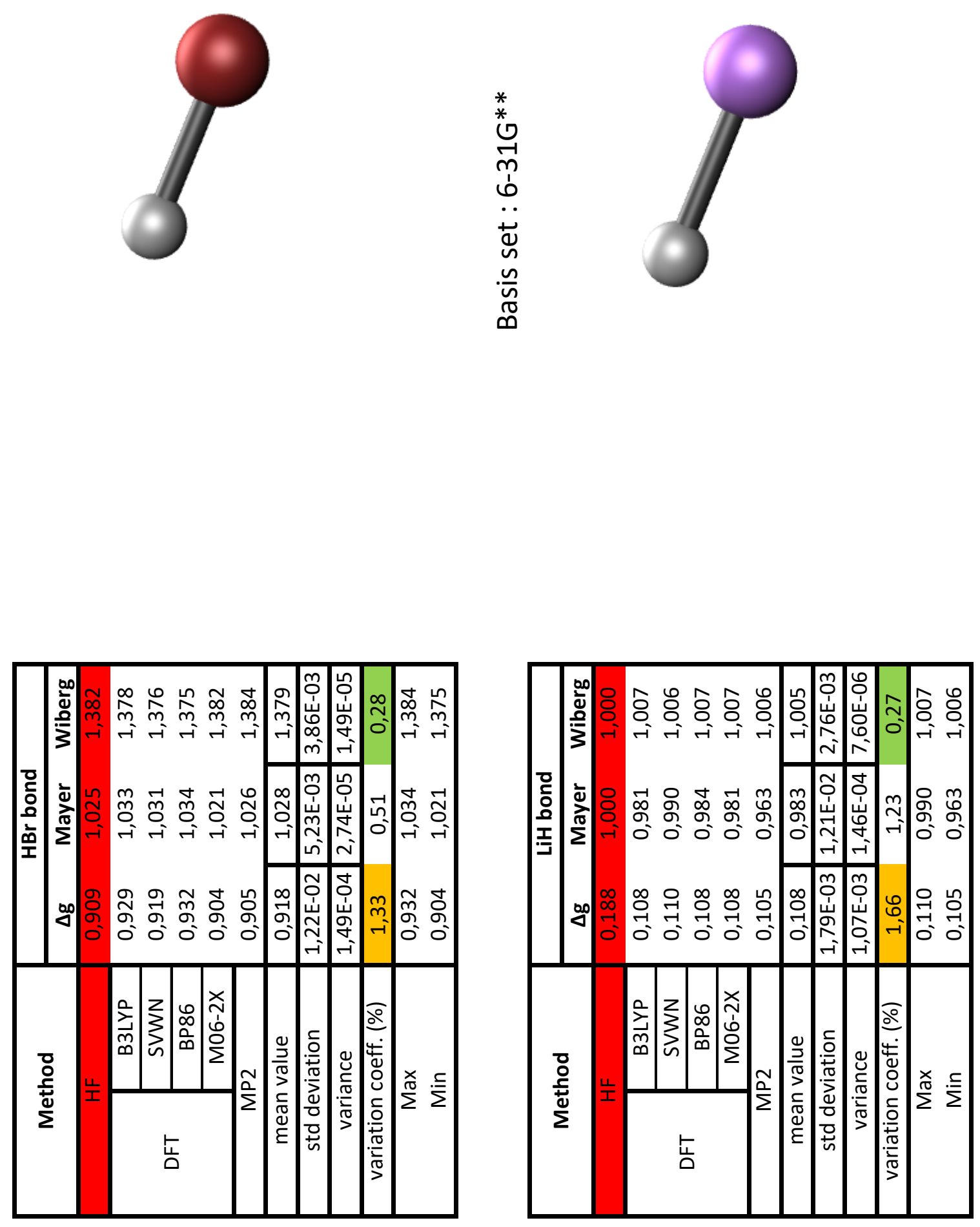


\section{IBSI compared with bond indices}

When we say bond property, we naturally think of bond order. That is the reason why we have first addressed the possible link between the IBSI and bond orders. In the following, for the sake of comparison across several bond indices, the IBSI is normalized to 1 for the $H_{2}$ molecule (see the section IGM bond index definition in the main text). We have performed a systematic study on 235 molecules and 677 different bonds covering a broad range of chemical bondings (non-covalent bonding, metal coordination and covalent bonds). Figure S1 (panels A and B) shows the correlation between the IBSI and the two bond orders: Mayer and Wiberg, respectively.

On the two plots, the points organize on a rather horizontal fashion, showing no clear tendency, the determination coefficients $R^{2}$ being 0.41 and 0.37 , respectively. The correlation

is worse with the Mulliken bond order $\left(R^{2}=0.27\right.$, panel $\left.\mathrm{E}\right)$. The ELF function belongs to another class of topological methods. Its analysis leads to a space partition into basins, some of which account for bonds. The electron population calculated over such disynaptic basins offers access to a bond population. When the bonding can be represented by a dominant mesomeric structure this ELF population should be approximately twice the expected bond order. $^{2}$ As shown in Figure S1 (panel C), the data on this plot are spread: the ELF bond order and the IBSI turn out to be mostly decorrelated $\left(R^{2}=0.007\right)$. Of the many bond indices considered in this work, the delocalization index (DI) has led to the less meaningless trend for the examined bonds $\left(R^{2}=0.46\right.$, Figure S1, panel D). Nevertheless, the DI is weakly correlated with the IBSI. 

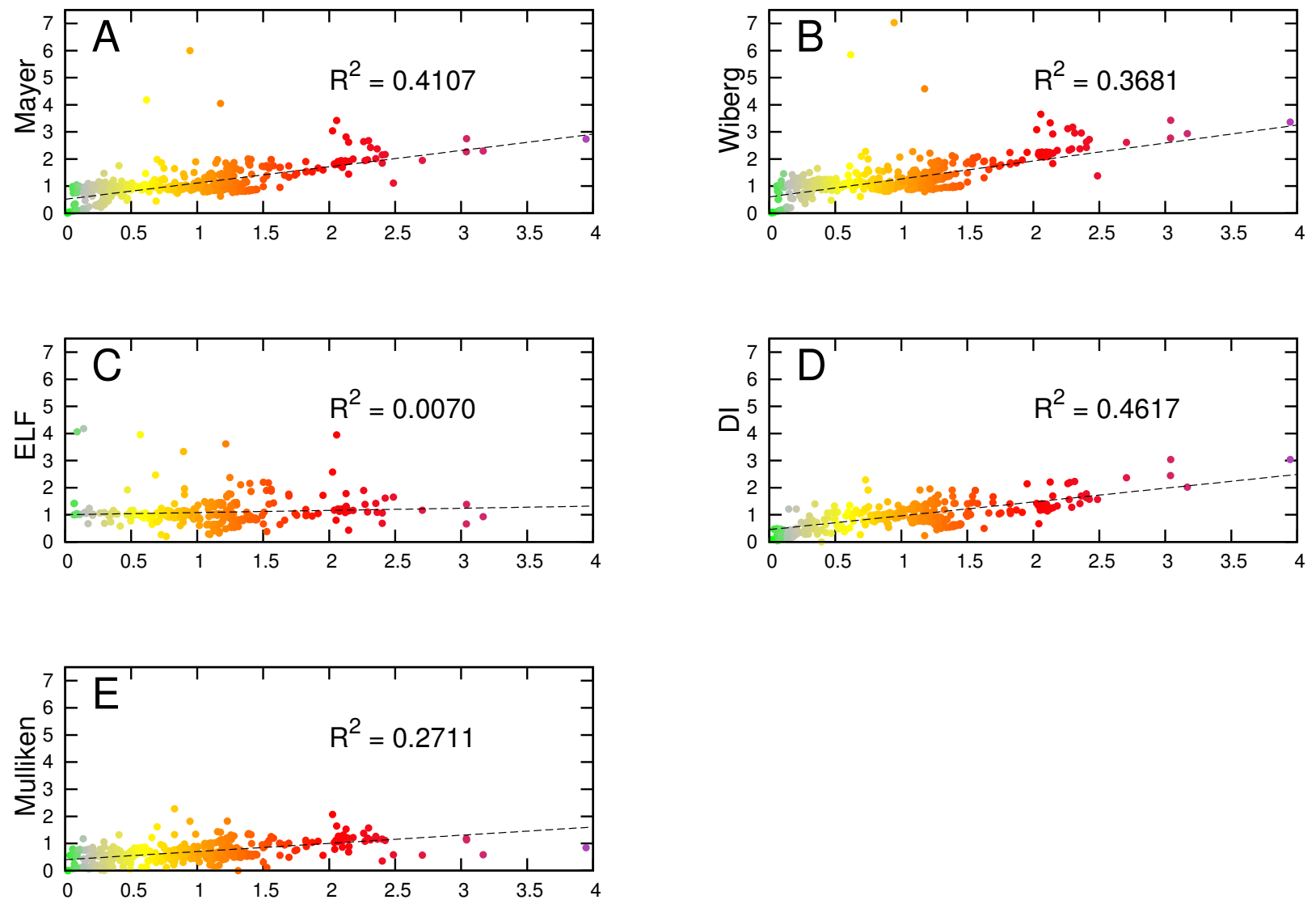

Figure S1: Linear correlation between the IBSI and (A) Mayer bond order, (B) Wiberg bond order (C) ELF index (from population analysis in disynaptic basins), (D) Delocalization Index (DI) and (E) Mulliken bond index. The points are colored using the color scale given in the main text.

\section{IBSI across the periodic table}

From a chemical perspective, the inspection of the IBSI computed for $\mathrm{H}-\mathrm{X}$ bonds across the periodic table undoubtedly shows a certain degree of consistency (see Figure S2, associated molecules are given below). The IBSI gradually increases from left to right along the second period of elements, from a low value for $\mathrm{H}-\mathrm{Li}(\mathrm{IBSI}=0.06)$ to the largest value for $\mathrm{H}-\mathrm{F}$ (IBSI=1.63). As we go down the halogen group the IBSI steadily drops from 1.63 to 0.35 for H-I. In contrast, the MBO remains approximately unchanged with a value around 1, which means that one electron pair is forming the bond regardless of the atom pair considered here. 


\begin{tabular}{|c|c|c|c|c|c|c|}
\hline $\mathbf{H}-\mathbf{H}$ & & & & & & \\
\hline$|B S|=1.000$ & & & & & & \\
\hline $\begin{array}{c}\mathrm{MBO}=1.000 \\
\mathrm{DI}=1.000\end{array}$ & & & & & & \\
\hline $\begin{array}{c}\text { H-Li } \\
|\mathrm{BS}|=0.056\end{array}$ & $\begin{array}{c}\text { H-Be } \\
|B S|=0.208\end{array}$ & $\begin{array}{c}\text { H-B } \\
|B S|=0.527\end{array}$ & $\begin{array}{c}\text { H-C } \\
|B S|=0.895\end{array}$ & $\begin{array}{c}\mathbf{H}-\mathbf{N} \\
|\mathrm{BS}|=1.203\end{array}$ & $\begin{array}{c}\mathbf{H}-\mathbf{O} \\
|\mathrm{BS}|=1.445\end{array}$ & $\begin{array}{c}\mathbf{H}-\mathbf{F} \\
|\mathrm{BS}|=1.628\end{array}$ \\
\hline $\begin{array}{c}\mathrm{MBO}=0.981 \\
\mathrm{DI}=0.228\end{array}$ & $\begin{array}{c}\mathrm{MBO}=0.997 \\
\mathrm{DI}=0.291\end{array}$ & $\begin{array}{c}\mathrm{MBO}=0.992 \\
\mathrm{DI}=0.554\end{array}$ & $\begin{array}{c}\mathrm{MBO}=0.975 \\
\mathrm{DI}=0.985\end{array}$ & $\begin{array}{c}\mathrm{MBO}=0.917 \\
\mathrm{DI}=0.881\end{array}$ & $\begin{array}{c}\mathrm{MBO}=0.887 \\
\mathrm{DI}=0.668\end{array}$ & $\begin{array}{c}\mathrm{MBO}=0.956 \\
\mathrm{DI}=0.497\end{array}$ \\
\hline $\begin{array}{c}\text { H-Na } \\
\text { IBSI }=0.067 \\
\text { MBO }=0.960 \\
\mathrm{DI}=0.465\end{array}$ & $\begin{array}{c}\text { H-Mg } \\
\text { IBSI }=0.111 \\
\text { MBO }=0.951 \\
\text { DI }=0.441\end{array}$ & $\begin{array}{c}\text { H-Al } \\
\text { IBSI }=0.210 \\
\text { MBO }=0.944 \\
\mathrm{DI}=0.427\end{array}$ & $\begin{array}{c}\mathbf{H}-\mathbf{S i} \\
\mathrm{IBSI}=0.345 \\
\mathrm{MBO}=0.933 \\
\mathrm{DI}=0.463\end{array}$ & $\begin{array}{c}\text { H-P } \\
\text { IBSI }=0.491 \\
\text { MBO }=0.963 \\
\text { DI }=0.847\end{array}$ & $\begin{array}{c}\text { H-S } \\
\mathrm{IBSI}=0.663 \\
\mathrm{MBO}=0.971 \\
\mathrm{DI}=1.108\end{array}$ & $\begin{array}{c}\mathbf{H}-\mathbf{C l} \\
\mathrm{IBSI}=0.817 \\
\mathrm{MBO}=0.991 \\
\mathrm{DI}=1.015\end{array}$ \\
\hline \multirow[t]{2}{*}{$\begin{array}{c}\text { H-K } \\
\mid \mathrm{BSI}=0.059 \\
\mathrm{MBO}=0.893 \\
\mathrm{DI}=0.488\end{array}$} & & & & & $\begin{array}{c}\text { H-Se } \\
\text { IBSI }=0.477 \\
\mathrm{MBO}=0.955 \\
\mathrm{DI}=1.092\end{array}$ & $\begin{array}{c}\text { H-Br } \\
\text { IBSI }=0.501 \\
\mathrm{MBO}=0.985 \\
\mathrm{DI}=1.117 \\
\end{array}$ \\
\hline & & & & & $\begin{array}{c}\text { H-Te } \\
\text { IBSI }=0.284 \\
\text { MBO }=0.959 \\
\mathrm{DI}=\mathrm{X}\end{array}$ & $\begin{array}{c}\text { H-I } \\
\mid \mathrm{BSI}=0.353 \\
\mathrm{MBO}=0.975 \\
\mathrm{DI}=\mathrm{X}\end{array}$ \\
\hline
\end{tabular}

Figure S2: Intrisic Bond Strength Index (IBSI) compared with the Mayer Bond Order (MBO) and Delocalization Index (DI) for H-X bonds across the periodic table; as explained in ESI, some DI value could not be obtained for some molecules for technical reasons $(\mathrm{DI}=\mathrm{X})$.

In these examples, the MBO is consistent with the chemical concept of two atoms connected by a formally predicted single bond H-X but it does not differentiate between these bonds. At the same time, the DI is found to be in the range 0.23-1.12. Along the second period, starting from $\mathrm{H}-\mathrm{Li}$, it continuously increases, goes through a maximum around $\mathrm{H}-\mathrm{C}(\mathrm{DI}=0.99)$, and next decreases. Along the third period, this behavior changes: the DI first decreases before increasing from H-C bond. This so-called electron sharing index measures the number of electron simultaneously fluctuating between the two atoms. However, for polar bonds, it has been previously shown that this delocalization index yields unrealistically lower bond orders than the Mayer bond order (MBO). It rather provides a covalent bond order. This is for instance what we observe for $\mathrm{H}-\mathrm{F}(\mathrm{DI}=0.50)$. This analysis shows that the IBSI has clearly a chemical meaning but does not hold the same information content as the MBO or the DI.

The following molecules have been considered across the periodic table. They have been optimized at the DFT(M06-2X)/6-31G** level of theory, except $\mathrm{H}_{2} \mathrm{Se}, \mathrm{H}_{2} \mathrm{Te}, \mathrm{HBr}$ and $\mathrm{HI}$ which were obtained at the DFT(B3LYP)/LANL2DZ level of theory. 


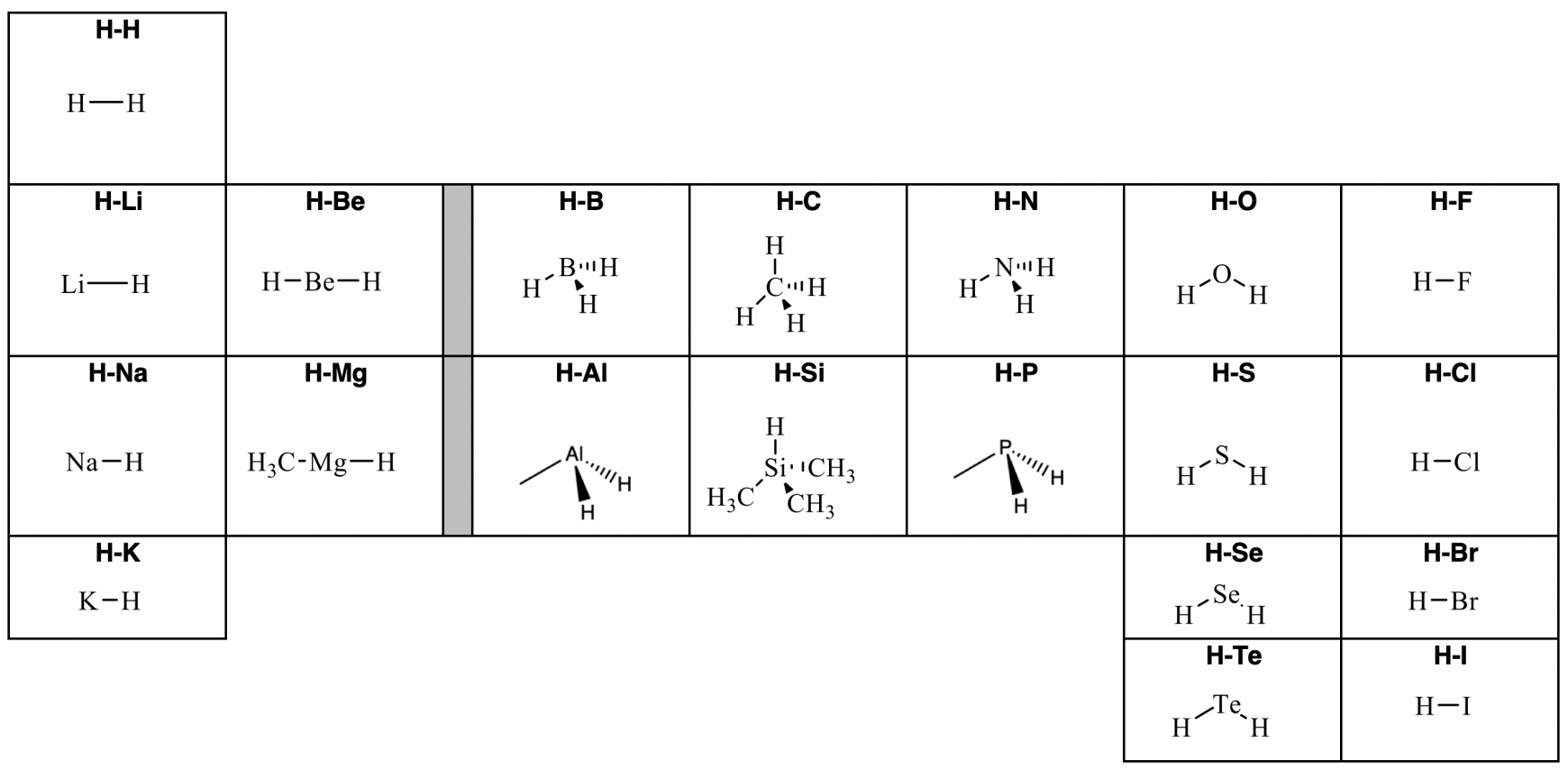

Figure S3

\section{Localized bond stretching force constants}

Local bond stretching force constant were also calculated as an estimator of bond strength in order to be compared with the IBSI. To derive a force constant $\mathrm{k}$ associated with a local vibrational mode between two atoms $\mathrm{X}$ and $\mathrm{Y}$, a numerical procedure was used in which the second derivative of the potential energy is numerically assessed at the DFT(M06-2X)/6$31 \mathrm{G}^{* *}$ level of theory if not otherwise stated. For this purpose, a second-order three-point central difference formula was employed to approximate the second derivative. Two versions were considered. In the first one, the molecule is divided into two rigid fragments around the XY bond, leading to a force constant hereafter called $k_{1}$. The two rigid fragments follow the XY dissociation motion (or compression). All atoms bonded to X (or Y) are slighly translated in the same direction. Their internal degrees of freedom are kept frozen upon the XY displacement. Unfortunately, this rigid fragmentation cannot be carried out when the $\mathrm{XY}$ bond belongs to a ring. In the second version, only $\mathrm{X}$ and $\mathrm{Y}$ are displaced, leading to a force constant called $k_{2}$. This second version is more general and can be applied to ring systems. In order to restrict electronic changes to the $\mathrm{XY}$ bond, both versions do 
not include a relaxation of the geometrical parameters of the molecule upon small bond stretching. The first version, although more inherent in the XY bond, may also include small contributions of the chemical environment surrounding the bond stretching. Actually, non-bonding interaction initially present between separating fragments will contribute to a small extent to $k_{1}$. Tests were carefully performed to assess how the step size for estimating the derivative influences the resulting force constant. A step of $0.01 \AA$ has been chosen.

In the following, the $k_{1}$ and $k_{2}$ local force constants have been obtained using the set1 of 184 molecules containing no ring (438 bonds). $k_{2}$ has also been obtained for the set2 of 51 ring-containing molecules (239 bonds).

\section{Correlation between the IBSI and force constants}

Four plots are reported here:

- $k_{1}=\mathrm{f}(\mathrm{IBSI})$ : linear and quadratic correlation between the IBSI and force constant $k_{1}$ (scheme 1) calculated using the set1 of molecules.

- $k_{2}=\mathrm{f}(\mathrm{IBSI})$ : linear and quadratic correlation between the IBSI and force constant $k_{2}$ (scheme 2) calculated using the set1 of molecules.

- $k_{2}=\mathrm{f}(\mathrm{IBSI})$ : linear and quadratic correlation between the IBSI and force constant $k_{2}$ (scheme 1) calculated using the set2 of ring-containing molecules.

- $k_{2}=\mathrm{f}(\mathrm{IBSI})$ : linear and quadratic correlation between the IBSI and force constant $k_{2}$ (scheme 2) calculated using the set1+set2 of molecules. 

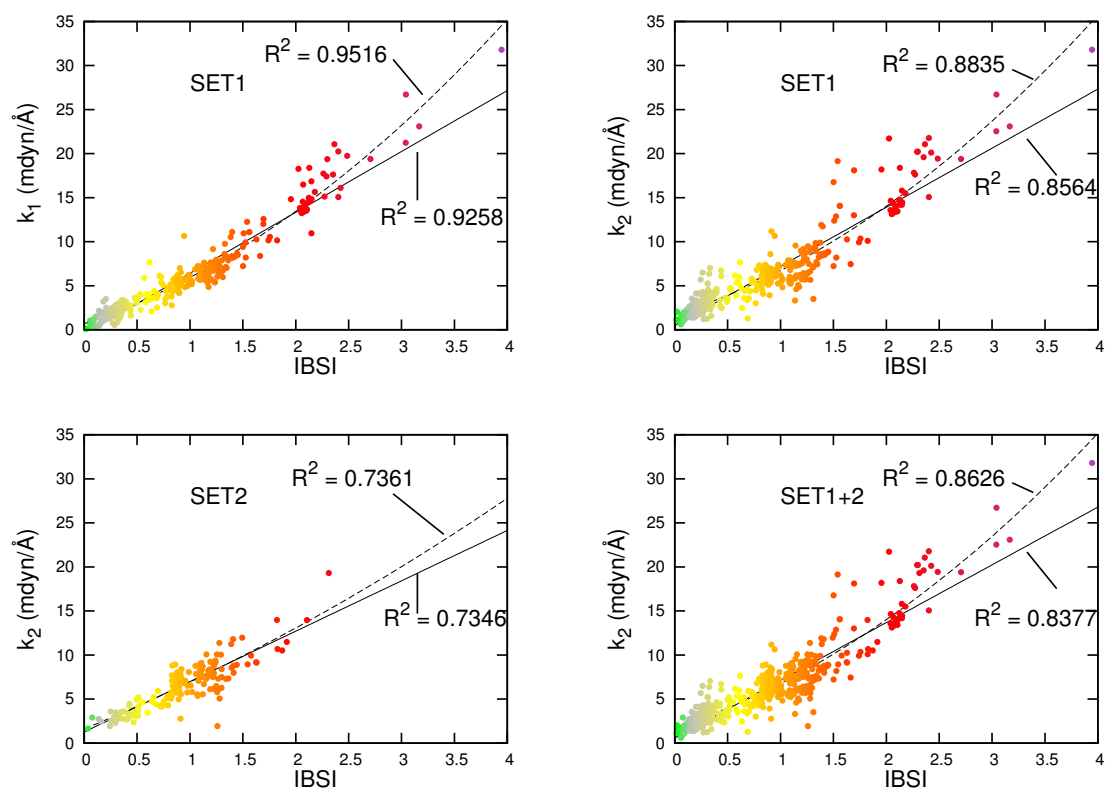

Figure S4: The points are colored using the color scale given in the main text. 


\section{Study of 677 bonds}

For a total set of 677 bonds in 235 molecules, the following table gives the:

- Intrinsic Bond Strength Index (IBSI) calculated using a modified version of NCIPlot;

$$
\Delta g^{\text {pair }}=\frac{\int_{V} \frac{\delta g^{\text {pair }}}{d^{2}} d V}{\int_{V} \frac{\delta g^{H_{2}}}{d_{H_{2}}^{2}} d V}
$$

In the following, for the sake of comparison across several bond indices, the IBSI was normalized to 1 for the $H_{2}$ molecule. The gross value obtained for $H_{2}$ at the M06$2 \mathrm{X} / 6-31 \mathrm{G}^{* *}$ level of theory (at the denominator, 0.7381 ) is now used by the program to normalize every IBSI value. As a consequence, the IBSI is dimensionless.

- Mayer bond order calculated using MultiWFN

- Wiberg bond order calculated using MultiWFN

- Mulliken bond order calculated using MultiWFN

- Delocalization index (DI) calculated using the AIMAll program; for some technical reason, a few molecules could not be processed by the AIMall program (like for instance HI or $\left.\mathrm{H}_{2} \mathrm{Te}\right)$.

- ELF index; within the framework of the topological analysis of ELF the space is partitioned into basins of attractors, each of them having a chemical meaning. Such basins are classified as: i) core basins surrounding nuclei, and ii) valence basins characterized by their synaptic order. A core basin, $\mathrm{C}(\mathrm{X})$ is usually representative of electrons not involved in the chemical bonding, namely non-valence and internal-shell electrons. The valence basins are distinguished according to the number of core basins with which they share a common boundary (synaptic order). A valence basin $\mathrm{V}(\mathrm{X})$ is monosynaptic and corresponds to lone-pair or non-bonding regions. $\mathrm{A} V(\mathrm{X}, \mathrm{Y})$ basin is disynaptic. 
It connects the core of two atoms $\mathrm{X}$ and $\mathrm{Y}$ and, thus, corresponds to a bonding region between $\mathrm{X}$ and $\mathrm{Y}$. The valence shell of an atom in a molecule is the combination of the valence basins. When the bonding can be represented by one dominant mesomeric structure, the $\mathrm{V}(\mathrm{X}, \mathrm{Y})$ basin population should be approximately twice the expected bond order; for some molecules (such hydrogen-bonded complexes), no ELF valence disynaptic basin was found, preventing the calculation of the ELF bond index (indicated by a blue cell and marked with an asterisk * in the table). Also, for technical reasons, WFN generated after a pseudo-potential-based calculation could not be read for ELF predictions (indicated by a blue cell and marked with two asterisks ** in the table).

- local bond stretching force constants calculated using the Gaussian program and a second-order three-point central difference formula.

Some energy calculations did not converge using the M06-2X DFT functional. In that case, the alternative B3LYP has been employed (indicated by a red square in the first column). Also, sometimes the use of a the Los Alamos effective core potential was used through the LANL2DZ basis set specification in gaussian, for heavy atoms (indicated by a blue rhombus in the first column). Species involving metal atoms are highlighted in green in the second column. Non-covalent systems are highlighted in orange in the second column.

In summary, the following color codes have been used. If not otherwise stated, the standard M06-2X 6-31G** level of theory has been employed.

\begin{tabular}{c}
\hline B3LYP calculations instead of M06-2X \\
LANL2DZ basis set instead of 6-31G** \\
No ELF valence disynaptic basin was found \\
$-\quad$ The ELF (or AIMall) program does not support ECP basis properly \\
Co-N \\
Containing a metal atom \\
N-H \\
\hline
\end{tabular}




\begin{tabular}{|c|c|c|c|c|c|c|c|c|c|c|c|c|}
\hline $\mathbf{N}^{\circ}$ & FORMULA & \multicolumn{3}{|c|}{ BOND (DIST. : ANGSTRÖMS) } & IBSI & Mayer & Wiberg & Mulliken & ELF & DI & $\mathbf{k}_{1}$ & $\mathbf{k}_{2}$ \\
\hline 1 & $\mathrm{H}_{2}$ & $1-2$ & $\mathrm{H}-\mathrm{H}$ & 0.737 & 1.000 & 1.000 & 1.000 & 0.829 & 1.000 & 1.000 & 6.18 & 6.18 \\
\hline 2 & $\mathrm{H}_{2} \mathrm{O}$ & $1-2$ & $\mathrm{O}-\mathrm{H}$ & 0.962 & 1.445 & 0.887 & 1.030 & 0.589 & 0.810 & 0.668 & 8.68 & 8.81 \\
\hline 3 & $\mathrm{CH}_{4}$ & $1-2$ & $\mathrm{C}-\mathrm{H}$ & 1.090 & 0.895 & 0.975 & 0.988 & 0.788 & 0.990 & 0.985 & 5.54 & 6.18 \\
\hline 4 & $\mathrm{NH}_{3}$ & $1-2$ & $\mathrm{~N}-\mathrm{H}$ & 1.015 & 1.203 & 0.917 & 1.004 & 0.688 & 0.940 & 0.881 & 7.24 & 7.55 \\
\hline 5 & $\mathrm{BH}_{3}$ & $1-2$ & B-H & 1.190 & 0.527 & 0.992 & 0.999 & 0.825 & 1.000 & 0.554 & 4.04 & 4.63 \\
\hline 6 & $\mathrm{BeH}_{2}$ & $1-2$ & $\mathrm{Be}-\mathrm{H}$ & 1.328 & 0.208 & 0.997 & 0.999 & 0.859 & 0.985 & 0.291 & 2.50 & 3.13 \\
\hline 7 & $\mathrm{O}_{2}{ }^{+}$ & $1-2$ & $0-0$ & 1.120 & 3.167 & 2.297 & 2.939 & 0.587 & 0.930 & 2.018 & 23.09 & 23.09 \\
\hline 8 & ${ }^{3} \mathrm{O}_{2}$ & $1-2$ & $0-0$ & 1.198 & 2.402 & 1.845 & 2.425 & 0.352 & 0.685 & 1.775 & 15.06 & 15.06 \\
\hline 9 & $\mathrm{O}_{2}{ }^{2-}$ & $1-2$ & $0-0$ & 1.564 & 0.766 & 0.948 & 1.170 & 0.115 & 0.205 & 0.989 & 3.02 & 3.02 \\
\hline 10 & $\mathrm{O}_{2}^{--}$ & $1-2$ & O-O & 1.329 & 1.528 & 1.387 & 1.836 & 0.113 & 0.385 & 1.434 & 8.20 & 8.20 \\
\hline 11 & $\mathrm{H}_{3} \mathrm{C}-\mathrm{CH}_{3}$ & $\begin{array}{l}1-2 \\
1-6\end{array}$ & $\begin{array}{l}\mathrm{C}-\mathrm{C} \\
\mathrm{C}-\mathrm{H}\end{array}$ & $\begin{array}{l}1.526 \\
1.093\end{array}$ & $\begin{array}{l}0.832 \\
0.892\end{array}$ & $\begin{array}{l}1.006 \\
0.969\end{array}$ & $\begin{array}{l}1.114 \\
0.965\end{array}$ & $\begin{array}{l}0.713 \\
0.792\end{array}$ & $\begin{array}{l}0.905 \\
1.015\end{array}$ & $\begin{array}{l}1.014 \\
0.967\end{array}$ & $\begin{array}{l}4.73 \\
5.41\end{array}$ & $\begin{array}{l}5.56 \\
6.08\end{array}$ \\
\hline 12 & $\mathrm{H}_{3} \mathrm{C}_{2}-\mathrm{H}_{\mathrm{H}_{2}^{\prime}}^{-\mathrm{OH}}$ & $\begin{array}{l}1-2 \\
1-7 \\
7-9 \\
2-4 \\
\end{array}$ & $\begin{array}{l}\mathrm{C}-\mathrm{C} \\
\mathrm{C}-\mathrm{O} \\
\mathrm{O}-\mathrm{H} \\
\mathrm{C}-\mathrm{H} \\
\end{array}$ & $\begin{array}{l}1.516 \\
1.415 \\
0.963 \\
1.093\end{array}$ & $\begin{array}{l}0.844 \\
1.099 \\
1.452 \\
0.895\end{array}$ & $\begin{array}{l}1.011 \\
0.931 \\
0.874 \\
0.962\end{array}$ & $\begin{array}{l}1.097 \\
1.148 \\
1.006 \\
0.956\end{array}$ & $\begin{array}{l}0.745 \\
0.474 \\
0.583 \\
0.754\end{array}$ & $\begin{array}{l}0.950 \\
0.620 \\
0.830 \\
1.025\end{array}$ & $\begin{array}{l}0.970 \\
0.882 \\
0.655 \\
0.959\end{array}$ & $\begin{array}{l}4.82 \\
5.95 \\
8.52 \\
5.08 \\
\end{array}$ & $\begin{array}{l}5.81 \\
5.81 \\
8.87 \\
5.88 \\
\end{array}$ \\
\hline 13 & $\mathrm{H}_{2} \mathrm{C}=\mathrm{CH}_{2}$ & $\begin{array}{l}1-2 \\
2-3\end{array}$ & $\begin{array}{l}\mathrm{C}-\mathrm{C} \\
\mathrm{C}-\mathrm{H}\end{array}$ & $\begin{array}{l}1.327 \\
1.086\end{array}$ & $\begin{array}{l}1.385 \\
0.904\end{array}$ & $\begin{array}{l}2.010 \\
0.960\end{array}$ & $\begin{array}{l}2.125 \\
0.951\end{array}$ & $\begin{array}{l}1.333 \\
0.791\end{array}$ & $\begin{array}{l}0.875 \\
1.750\end{array}$ & $\begin{array}{l}1.913 \\
0.973\end{array}$ & $\begin{array}{c}10.53 \\
5.73\end{array}$ & $\begin{array}{c}11.91 \\
6.96 \\
\end{array}$ \\
\hline 14 & $\mathrm{HC} \equiv \mathrm{CH}$ & $\begin{array}{l}1-2 \\
2-3\end{array}$ & $\begin{array}{l}\mathrm{C}-\mathrm{C} \\
\mathrm{C}-\mathrm{H}\end{array}$ & $\begin{array}{l}1.203 \\
1.067\end{array}$ & $\begin{array}{l}2.026 \\
0.913\end{array}$ & $\begin{array}{l}3.038 \\
0.935\end{array}$ & $\begin{array}{l}3.083 \\
0.936\end{array}$ & $\begin{array}{l}2.071 \\
0.727\end{array}$ & $\begin{array}{l}2.575 \\
1.115 \\
\end{array}$ & $\begin{array}{l}1.422 \\
0.961\end{array}$ & $\begin{array}{c}18.28 \\
6.52\end{array}$ & $\begin{array}{l}21.72 \\
11.18\end{array}$ \\
\hline 15 & & $\begin{array}{l}1-2 \\
2-3 \\
1-8 \\
\end{array}$ & $\begin{array}{l}\mathrm{C}-\mathrm{C} \\
\mathrm{C}-\mathrm{H} \\
\mathrm{C}-\mathrm{F}\end{array}$ & $\begin{array}{l}1.512 \\
1.092 \\
1.382\end{array}$ & $\begin{array}{l}0.852 \\
0.889 \\
1.127 \\
\end{array}$ & $\begin{array}{l}1.002 \\
0.961 \\
0.905\end{array}$ & $\begin{array}{l}1.105 \\
0.957 \\
1.118\end{array}$ & $\begin{array}{l}0.713 \\
0.778 \\
0.494\end{array}$ & $\begin{array}{l}0.960 \\
1.000 \\
0.425\end{array}$ & $\begin{array}{l}0.975 \\
0.963 \\
0.795\end{array}$ & $\begin{array}{l}4.79 \\
5.28 \\
6.24 \\
\end{array}$ & $\begin{array}{l}5.80 \\
6.15 \\
5.90 \\
\end{array}$ \\
\hline 16 & $\mathrm{~F}_{3} \mathrm{C}-\mathrm{CF}_{3}$ & $\begin{array}{l}1-2 \\
1-3\end{array}$ & $\begin{array}{l}\mathrm{C}-\mathrm{C} \\
\mathrm{C}-\mathrm{F}\end{array}$ & $\begin{array}{l}1.534 \\
1.328 \\
\end{array}$ & $\begin{array}{l}0.797 \\
1.311 \\
\end{array}$ & $\begin{array}{l}0.901 \\
1.028\end{array}$ & $\begin{array}{l}0.897 \\
1.254\end{array}$ & $\begin{array}{l}0.633 \\
0.573\end{array}$ & $\begin{array}{l}1.130 \\
0.560\end{array}$ & $\begin{array}{l}0.740 \\
0.653\end{array}$ & $\begin{array}{l}4.75 \\
5.98 \\
\end{array}$ & $\begin{array}{l}7.32 \\
3.51 \\
\end{array}$ \\
\hline 17 & $\mathrm{H}_{3} \mathrm{C}-\mathrm{CF}_{3}$ & $\begin{array}{l}1-2 \\
1-3 \\
2-6 \\
\end{array}$ & $\begin{array}{l}\mathrm{C}-\mathrm{C} \\
\mathrm{C}-\mathrm{H} \\
\mathrm{C}-\mathrm{F} \\
\end{array}$ & $\begin{array}{l}1.501 \\
1.090 \\
1.342 \\
\end{array}$ & $\begin{array}{l}0.882 \\
0.891 \\
1.258 \\
\end{array}$ & $\begin{array}{l}1.016 \\
0.944 \\
1.012 \\
\end{array}$ & $\begin{array}{l}1.065 \\
0.944 \\
1.213 \\
\end{array}$ & $\begin{array}{l}0.769 \\
0.730 \\
0.597 \\
\end{array}$ & $\begin{array}{l}1.025 \\
1.015 \\
0.535 \\
\end{array}$ & $\begin{array}{l}0.892 \\
0.952 \\
0.647 \\
\end{array}$ & $\begin{array}{l}5.04 \\
5.57 \\
6.76 \\
\end{array}$ & $\begin{array}{l}6.54 \\
6.37 \\
6.44 \\
\end{array}$ \\
\hline 18 & $\left(\mathrm{CH}_{3}\right)_{3} \mathrm{C}-\mathrm{CF}_{3}$ & $\begin{array}{c}1-2 \\
1-3 \\
2-6 \\
6-12\end{array}$ & $\begin{array}{l}\mathrm{C}-\mathrm{C} \\
\mathrm{C}-\mathrm{F} \\
\mathrm{C}-\mathrm{C} \\
\mathrm{C}-\mathrm{H}\end{array}$ & $\begin{array}{l}1.519 \\
1.344 \\
1.531 \\
1.093\end{array}$ & $\begin{array}{l}0.844 \\
1.252 \\
0.830 \\
0.891\end{array}$ & $\begin{array}{l}0.959 \\
0.993 \\
0.982 \\
0.959\end{array}$ & $\begin{array}{l}0.971 \\
1.204 \\
1.031 \\
0.953\end{array}$ & $\begin{array}{l}0.713 \\
0.594 \\
0.658 \\
0.772\end{array}$ & $\begin{array}{l}1.065 \\
0.550 \\
0.945 \\
0.797\end{array}$ & $\begin{array}{l}0.851 \\
0.643 \\
0.957 \\
0.954\end{array}$ & $\begin{array}{l}4.84 \\
6.73 \\
4.66 \\
4.47\end{array}$ & $\begin{array}{l}6.18 \\
6.40 \\
5.56 \\
5.64\end{array}$ \\
\hline 19 & & $\begin{array}{l}1-2 \\
2-3\end{array}$ & $\begin{array}{l}\mathrm{C}-\mathrm{C} \\
\mathrm{C}-\mathrm{H}\end{array}$ & $\begin{array}{l}1.516 \\
1.094\end{array}$ & $\begin{array}{l}0.833 \\
0.882 \\
1.137\end{array}$ & $\begin{array}{l}0.967 \\
0.943\end{array}$ & $\begin{array}{l}1.060 \\
0.937\end{array}$ & $\begin{array}{l}0.663 \\
0.756\end{array}$ & $\begin{array}{l}0.980 \\
1.015 \\
0.440\end{array}$ & $\begin{array}{l}0.917 \\
0.915 \\
0.800\end{array}$ & $\begin{array}{l}4.72 \\
6.20\end{array}$ & $\begin{array}{l}5.40 \\
5.95\end{array}$ \\
\hline
\end{tabular}




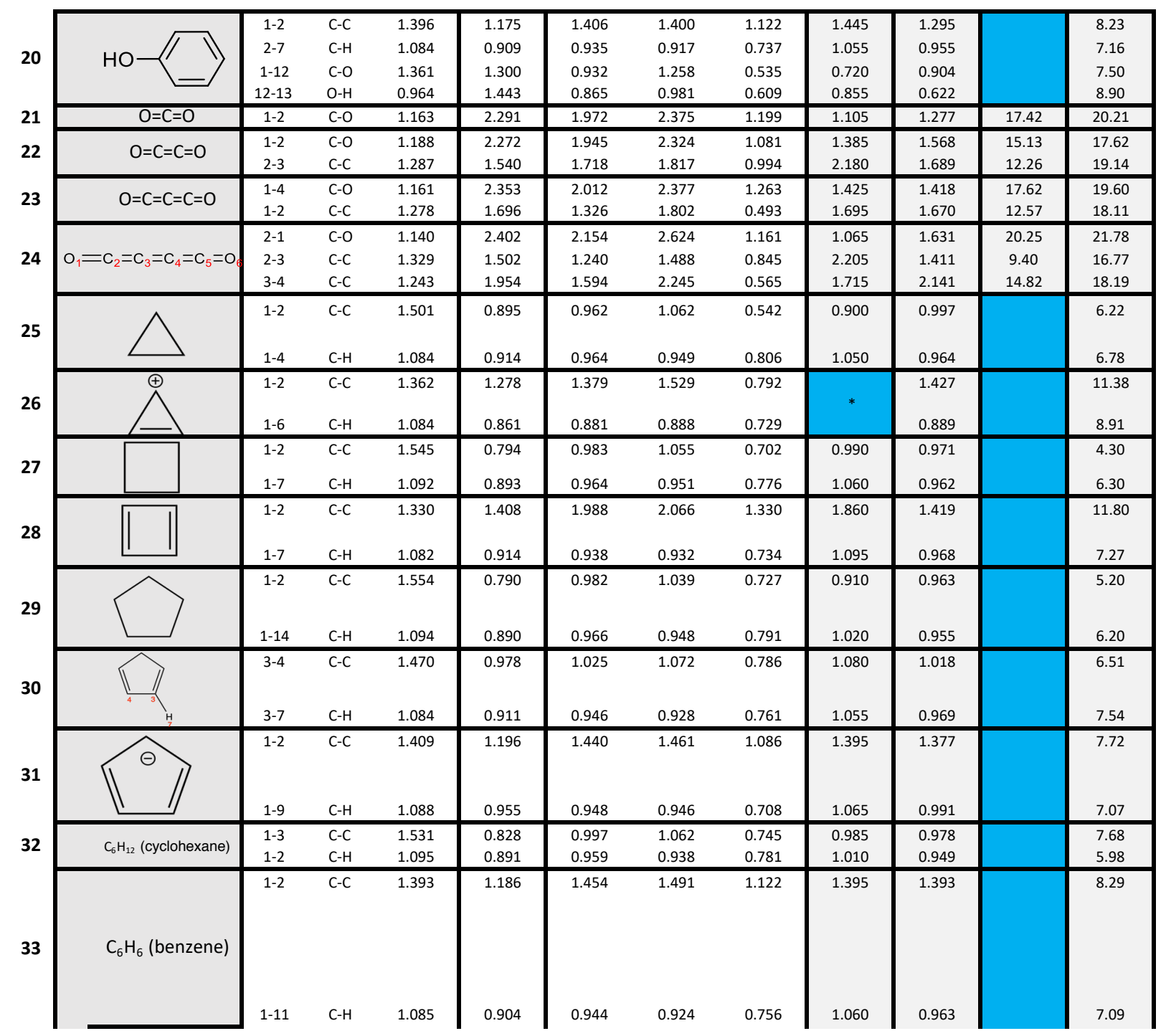




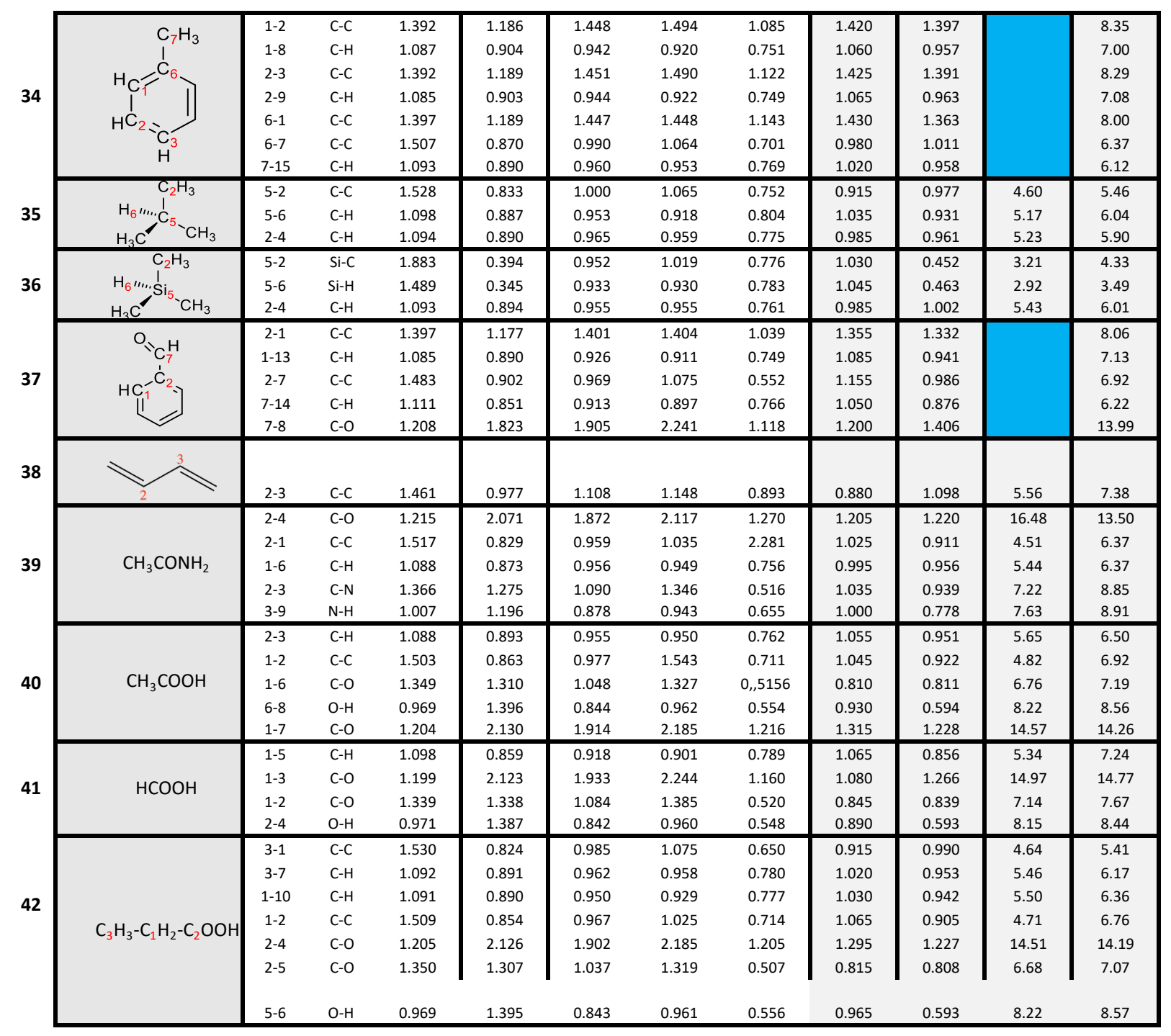




\begin{tabular}{|c|c|c|c|c|c|c|c|c|c|c|c|c|}
\hline \multirow{6}{*}{43} & $\mathrm{H}$ & $7-20$ & $\mathrm{~N}-\mathrm{H}$ & 1.013 & 1.225 & 0.904 & 0.956 & 0.704 & 1.030 & 0.847 & & 7.93 \\
\hline & & $1-7$ & C-N & 1.462 & 1.020 & 0.964 & 1.106 & 0.584 & 0.865 & 0.965 & & 5.80 \\
\hline & & $1-8$ & $\mathrm{C}-\mathrm{H}$ & 1.104 & 0.872 & 0.947 & 0.927 & 0.765 & 1.030 & 0.915 & & 5.73 \\
\hline & & $2-1$ & $C-C$ & 1.530 & 0.824 & 0.981 & 1.057 & 0.730 & 0.950 & 0.955 & & 5.39 \\
\hline & & $3-2$ & $C-C$ & 1.530 & 0.829 & 1.008 & 1.068 & 0.761 & 0.950 & 0.980 & & 5.44 \\
\hline & & 4-3 & $C-C$ & 1.534 & 0.822 & 0.998 & 1.061 & 0.738 & 0.950 & 0.976 & & 5.31 \\
\hline \multirow{4}{*}{44} & \multirow{4}{*}{$\mathrm{H}_{2} \mathrm{~N}-\mathrm{CO}-\mathrm{CO}-\mathrm{NH}_{2}$} & $1-2$ & $C-C$ & 1.544 & 0.776 & 0.875 & 0.900 & 0.585 & 1.165 & 0.786 & 4.35 & 6.79 \\
\hline & & $1-5$ & $\mathrm{C}-\mathrm{O}$ & 1.219 & 2.078 & 1.782 & 2.069 & 1.150 & 1.125 & 1.205 & 13.41 & 13.36 \\
\hline & & $2-4$ & $\mathrm{C}-\mathrm{N}$ & 1.342 & 1.376 & 1.149 & 1.423 & 0.530 & 1.095 & 0.993 & 8.14 & 9.90 \\
\hline & & $4-10$ & $\mathrm{~N}-\mathrm{H}$ & 1.009 & 1.192 & 0.846 & 0.921 & 0.675 & 0.990 & 0.769 & 7.53 & 8.99 \\
\hline \multirow{3}{*}{45} & \multirow{3}{*}{$\mathrm{H}_{2} \mathrm{~N}-\mathrm{CO}-\mathrm{NH}_{2}$} & $1-2$ & $\mathrm{C}-\mathrm{O}$ & 1.214 & 2.107 & 1.873 & 2.085 & 1.309 & 1.210 & 1.137 & 13.68 & 13.45 \\
\hline & & $1-3$ & C-N & 1.385 & 1.223 & 1.052 & 1.271 & 0.580 & 1.180 & 0.898 & 6.73 & 8.08 \\
\hline & & $3-6$ & $\mathrm{~N}-\mathrm{H}$ & 1.009 & 1.210 & 0.884 & 0.948 & 0.676 & 0.995 & 0.809 & 7.50 & 8.57 \\
\hline \multirow{6}{*}{46} & & $1-2$ & $C-C$ & 1.499 & 0.876 & 0.994 & 1.067 & 0.748 & 1.085 & 0.931 & 4.85 & 6.95 \\
\hline & & $1-8$ & $\mathrm{C}-\mathrm{H}$ & 1.088 & 0.892 & 0.949 & 0.946 & 0.756 & 0.985 & 0.956 & 5.65 & 6.51 \\
\hline & & $2-3$ & $\mathrm{C}-\mathrm{O}$ & 1.198 & 2.150 & 1.914 & 2.216 & 0.893 & 1.145 & 1.262 & 14.82 & 14.47 \\
\hline & & $2-4$ & $\mathrm{C}-\mathrm{O}$ & 1.379 & 1.193 & 0.922 & 1.187 & 0.403 & 0.755 & 0.767 & 5.74 & 6.08 \\
\hline & & $5-6$ & $\mathrm{C}-\mathrm{O}$ & 1.190 & 2.181 & 1.999 & 2.317 & 1.216 & 1.165 & 1.329 & 15.65 & 15.50 \\
\hline & & $5-7$ & $\mathrm{C}-\mathrm{H}$ & 1.096 & 0.856 & 0.901 & 0.894 & 0.779 & 1.135 & 0.842 & 5.45 & 7.38 \\
\hline \multirow{3}{*}{47} & \multirow{3}{*}{$\mathrm{HO}_{1} \stackrel{\mathrm{O}}{\mathrm{HO}^{\prime}} \mathrm{S}_{1} \mathrm{O}_{5}$} & $1-2$ & $\mathrm{~S}-\mathrm{O}$ & 1.602 & 0.899 & 0.958 & 1.089 & 0.422 & 1.050 & 0.667 & 4.20 & 5.67 \\
\hline & & $2-6$ & $\mathrm{O}-\mathrm{H}$ & 0.971 & 1.377 & 0.827 & 0.961 & 0.589 & 0.855 & 0.564 & 8.20 & 8.51 \\
\hline & & $1-5$ & $\mathrm{~S}-\mathrm{O}$ & 1.435 & 1.525 & 1.753 & 1.865 & 0.992 & 1.895 & 1.002 & 9.92 & 12.88 \\
\hline \multirow{3}{*}{48} & \multirow{3}{*}{$\mathrm{CH}_{3}-\mathrm{SO}-\mathrm{CH}_{3}$} & $2-4$ & $\mathrm{~S}-\mathrm{O}$ & 1.503 & 1.248 & 1.478 & 1.680 & 0.669 & 2.375 & 1.326 & 7.95 & 7.99 \\
\hline & & $2-1$ & S-C & 1.815 & 0.580 & 0.861 & 1.027 & 0.121 & 0.935 & 0.958 & 3.13 & 3.87 \\
\hline & & $1-6$ & $\mathrm{C}-\mathrm{H}$ & 1.092 & 0.891 & 0.939 & 0.950 & 0.670 & 1.025 & 0.962 & 5.55 & 6.16 \\
\hline \multirow{13}{*}{49} & \multirow{13}{*}{ 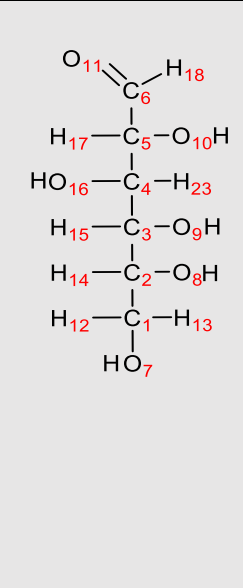 } & $1-7$ & $\mathrm{C}-\mathrm{O}$ & 1.405 & 1.138 & 0.942 & 1.180 & 0.505 & 0.640 & 0.890 & 6.22 & 5.95 \\
\hline & & $7-19$ & $\mathrm{O}-\mathrm{H}$ & 0.966 & 1.419 & 0.853 & 0.988 & 0.599 & 0.835 & 0.611 & 8.32 & 8.58 \\
\hline & & $1-12$ & $\mathrm{C}-\mathrm{H}$ & 1.103 & 0.874 & 0.936 & 0.925 & 0.738 & 1.035 & 0.904 & 5.03 & 5.80 \\
\hline & & $1-2$ & $C-C$ & 1.518 & 0.840 & 0.985 & 1.037 & 0.719 & 1.015 & 0.908 & 4.74 & 5.74 \\
\hline & & $2-8$ & $\mathrm{C}-\mathrm{O}$ & 1.419 & 1.086 & 0.907 & 1.133 & 0.418 & 0.650 & 0.854 & 5.79 & 5.63 \\
\hline & & $8-20$ & $\mathrm{O}-\mathrm{H}$ & 0.966 & 1.413 & 0.847 & 0.985 & 0.586 & 0.850 & 0.602 & 8.32 & 8.67 \\
\hline & & $2-14$ & $\mathrm{C}-\mathrm{H}$ & 1.098 & 0.876 & 0.934 & 0.903 & 0.767 & 1.040 & 0.886 & 5.22 & 6.16 \\
\hline & & $5-6$ & $C-C$ & 1.517 & 0.825 & 0.925 & 1.011 & 0.592 & 1.015 & 0.887 & 4.47 & 5.85 \\
\hline & & $5-17$ & $\mathrm{C}-\mathrm{H}$ & 1.103 & 0.864 & 0.917 & 0.887 & 0.737 & 1.050 & 0.889 & 5.03 & 5.77 \\
\hline & & $5-10$ & $\mathrm{C}-\mathrm{O}$ & 1.405 & 1.144 & 0.925 & 1.162 & 0.473 & 0.650 & 0.873 & 6.13 & 5.89 \\
\hline & & $10-22$ & $\mathrm{O}-\mathrm{H}$ & 0.972 & 1.362 & 0.808 & 0.950 & 0.593 & 0.865 & 0.542 & 7.87 & 8.23 \\
\hline & & $6-11$ & $\mathrm{C}-\mathrm{O}$ & 1.206 & 2.066 & 1.906 & 2.258 & 1.067 & 1.215 & 1.408 & 14.52 & 14.32 \\
\hline & & $6-18$ & $\mathrm{C}-\mathrm{H}$ & 1.105 & 0.848 & 0.906 & 0.902 & 0.740 & 1.070 & 0.879 & 5.06 & 6.60 \\
\hline
\end{tabular}




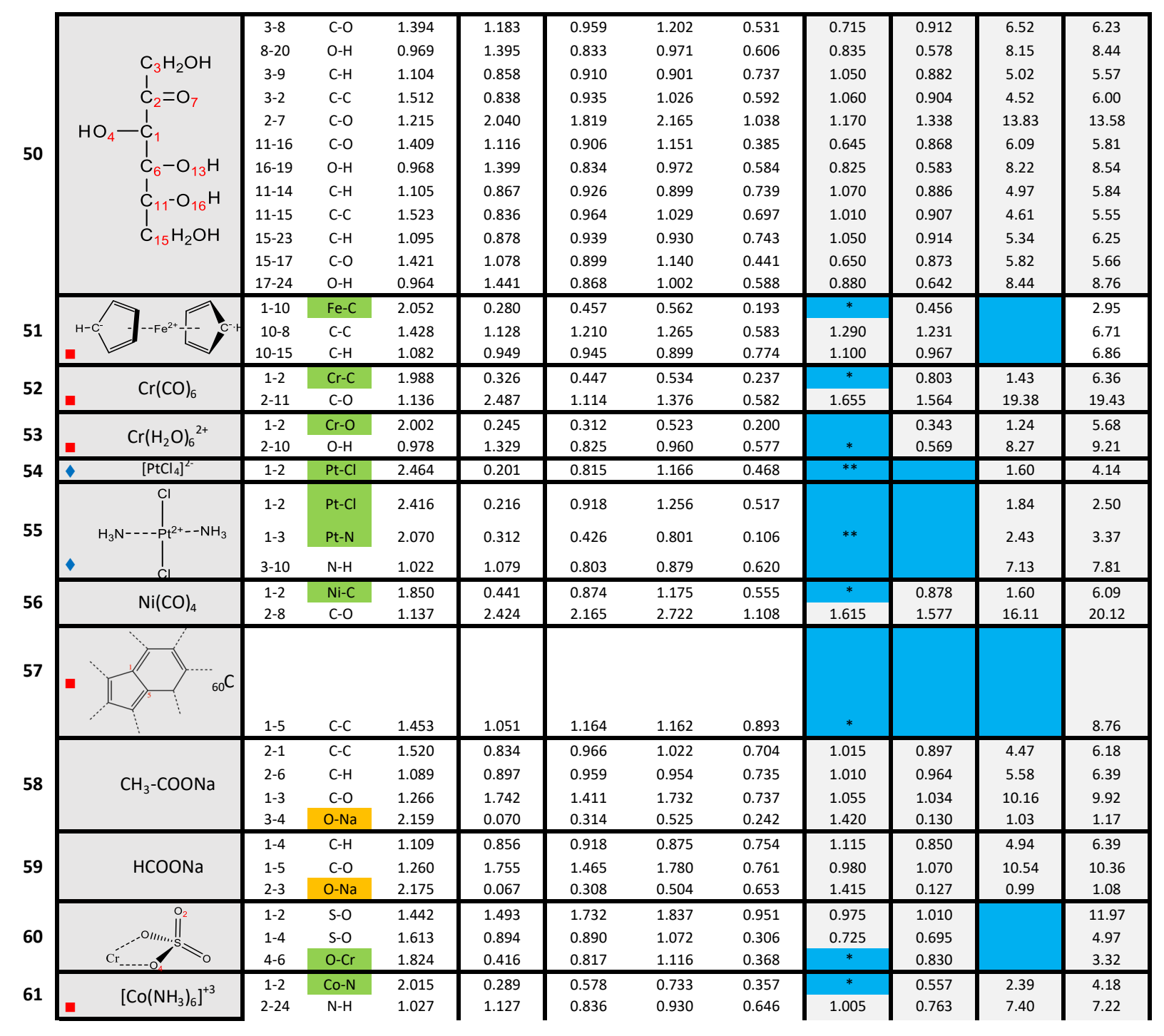




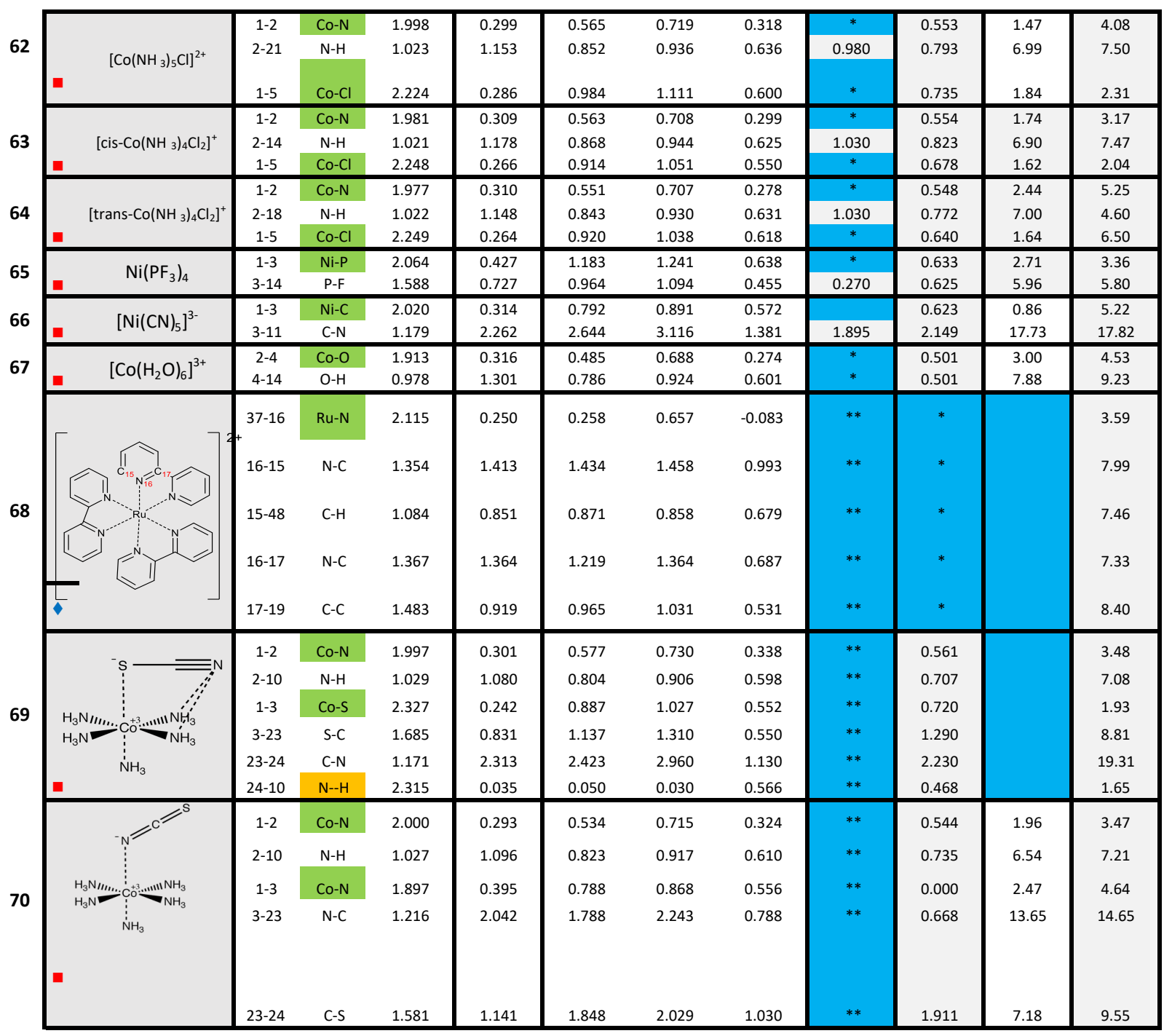




\begin{tabular}{|c|c|c|c|c|c|c|c|c|c|c|c|c|}
\hline & & $2-1$ & Re-S & 2.391 & 0.254 & 1.154 & 1.244 & 0.604 & ** & & & 2.52 \\
\hline & & $1-13$ & $\mathrm{~S}-\mathrm{C}$ & 1.747 & 0.678 & 1.240 & 1.405 & 0.583 & ** & & & 4.43 \\
\hline & & $13-16$ & $\mathrm{C}-\mathrm{C}$ & 1.533 & 0.828 & 0.890 & 0.975 & 0.315 & ** & & & 5.77 \\
\hline \multirow{2}{*}{71} & & $16-32$ & C-F & 1.375 & 1.121 & 1.045 & 1.153 & 0.554 & $* *$ & & & 5.55 \\
\hline & • & $13-12$ & $c-c$ & 1.381 & 1.223 & 1.154 & 1.526 & -0.491 & ** & & & 7.92 \\
\hline \multirow{4}{*}{72} & & $1-2$ & S-C & 1.755 & 0.713 & 0.868 & 1.129 & 0.368 & 0.805 & 1.115 & 6.13 & 4.38 \\
\hline & $\mathrm{C}_{2} \mathrm{H}_{2}=\mathrm{S}\left(\mathrm{C}_{3} \mathrm{H}_{3}\right)_{2}$ & $2-12$ & $\mathrm{C}-\mathrm{H}$ & 1.072 & 0.986 & 0.952 & 0.973 & 0.814 & 1.050 & 1.010 & 6.22 & 7.15 \\
\hline & & $1-3$ & $S-C$ & 1.779 & 0.684 & 0.967 & 1.099 & 0.656 & 2.470 & 1.043 & 3.65 & 4.59 \\
\hline & & $1-2$ & $\mathrm{~S}-\mathrm{C}$ & 1.639 & 0.976 & 1.498 & 1.523 & 0.870 & 1.220 & 1.350 & 5.68 & 7.10 \\
\hline \multirow{3}{*}{73} & & $2-13$ & $C-H$ & 1.085 & 0.930 & 0.943 & 0.944 & 0.775 & 1.015 & 0.975 & 5.73 & 6.42 \\
\hline & & $1-4$ & $\mathrm{~S}-\mathrm{C}$ & 1.795 & 0.627 & 0.861 & 0.972 & 0.371 & 0.970 & 0.903 & 3.42 & 4.75 \\
\hline & $\mathrm{C}_{2} \mathrm{H}_{2}$ & $1-5$ & S-O & 1.486 & 1.326 & 1.579 & 1.678 & 0.762 & 0.785 & 1.186 & 8.61 & 9.31 \\
\hline \multirow{3}{*}{74} & & $2-1$ & $\mathrm{P}-\mathrm{C}$ & 1.673 & 0.828 & 1.649 & 1.582 & 1.330 & 1.410 & 0.974 & 5.66 & 6.88 \\
\hline & & $1-7$ & $\mathrm{C}-\mathrm{H}$ & 1.084 & 0.940 & 0.945 & 0.952 & 0.774 & 1.005 & 1.033 & 5.76 & 6.47 \\
\hline & $\mathrm{H}_{3} \mathrm{C}$ & $2-4$ & P-C & 1.824 & 0.534 & 0.936 & 1.010 & 0.586 & 1.000 & 0.645 & 3.47 & 4.66 \\
\hline \multirow{3}{*}{75} & & $2-1$ & $\mathrm{~N}-\mathrm{C}$ & 1.274 & 1.694 & 1.744 & 1.959 & 1.013 & 1.760 & 1.452 & 12.02 & 13.01 \\
\hline & & $1-12$ & $C-H$ & 1.086 & 0.856 & 0.920 & 0.920 & 0.780 & 1.015 & 0.892 & 5.76 & 7.35 \\
\hline & & $2-3$ & $\mathrm{~N}-\mathrm{C}$ & 1.475 & 0.953 & 0.846 & 1.027 & 0.439 & 0.950 & 0.872 & 4.85 & 6.04 \\
\hline \multirow{3}{*}{76} & & $5-7$ & $C-C$ & 1.515 & 0.842 & 0.956 & 1.056 & 0.648 & 1.020 & 0.941 & 4.39 & 6.01 \\
\hline & & $7-10$ & $\mathrm{C}-\mathrm{H}$ & 1.089 & 0.888 & 0.956 & 0.952 & 0.740 & 1.005 & 0.956 & 5.58 & 6.39 \\
\hline & & $5-6$ & C-O & 1.209 & 2.091 & 1.943 & 2.234 & 1.212 & 1.200 & 1.384 & 14.33 & 14.04 \\
\hline \multirow{5}{*}{77} & & $2-1$ & $C-C$ & 1.548 & 0.782 & 0.921 & 0.997 & 0.564 & 0.985 & 0.892 & 3.73 & 4.96 \\
\hline & & $1-7$ & $\mathrm{C}-\mathrm{H}$ & 1.096 & 0.902 & 0.961 & 0.966 & 0.621 & 1.005 & 0.969 & 5.24 & 5.98 \\
\hline & & $2-4$ & C-O & 1.267 & 1.824 & 1.526 & 1.804 & 1.067 & 0.970 & 1.148 & 10.15 & 10.09 \\
\hline & & $2-3$ & $C-C$ & 1.378 & 1.260 & 1.590 & 1.643 & 1.153 & 1.295 & 1.483 & 6.04 & 9.49 \\
\hline & & 3-9 & $\mathrm{C}-\mathrm{H}$ & 1.086 & 0.964 & 0.943 & 0.970 & 0.655 & 1.015 & 1.007 & 5.62 & 6.69 \\
\hline \multirow{10}{*}{\multicolumn{2}{|c|}{78}} & $2-1$ & $C-C$ & 1.516 & 0.836 & 0.933 & 0.980 & 0.642 & 1.070 & 0.881 & & 6.53 \\
\hline & & $1-10$ & C-O & 1.207 & 2.106 & 1.844 & 2.154 & 1.114 & 1.220 & 1.208 & & 13.96 \\
\hline & & $1-9$ & C-O & 1.345 & 1.340 & 1.057 & 1.344 & 0.565 & 0.795 & 0.815 & & 7.29 \\
\hline & & $9-11$ & $\mathrm{O}-\mathrm{H}$ & 0.970 & 1.395 & 0.845 & 0.958 & 0.564 & 0.920 & 0.593 & & 8.54 \\
\hline & & $2-4$ & $C-C$ & 1.529 & 0.830 & 0.991 & 1.049 & 0.684 & 0.955 & 0.972 & & 5.39 \\
\hline & & $2-3$ & $C-C$ & 1.522 & 0.843 & 0.970 & 0.999 & 0.684 & 0.905 & 0.961 & & 5.85 \\
\hline & & 3-16 & $C-C$ & 1.398 & 1.184 & 1.424 & 1.431 & 1.084 & 1.435 & 1.351 & & 7.91 \\
\hline & & $16-21$ & $\mathrm{C}-\mathrm{H}$ & 1.087 & 0.890 & 0.928 & 0.912 & 0.744 & 1.065 & 0.941 & & 7.01 \\
\hline & & $14-15$ & $C-C$ & 1.393 & 1.185 & 1.444 & 1.483 & 1.116 & 1.405 & 1.386 & & 8.25 \\
\hline & & $14-19$ & $\mathrm{C}-\mathrm{H}$ & 1.085 & 0.905 & 0.944 & 0.923 & 0.755 & 1.050 & 0.962 & & 7.10 \\
\hline
\end{tabular}




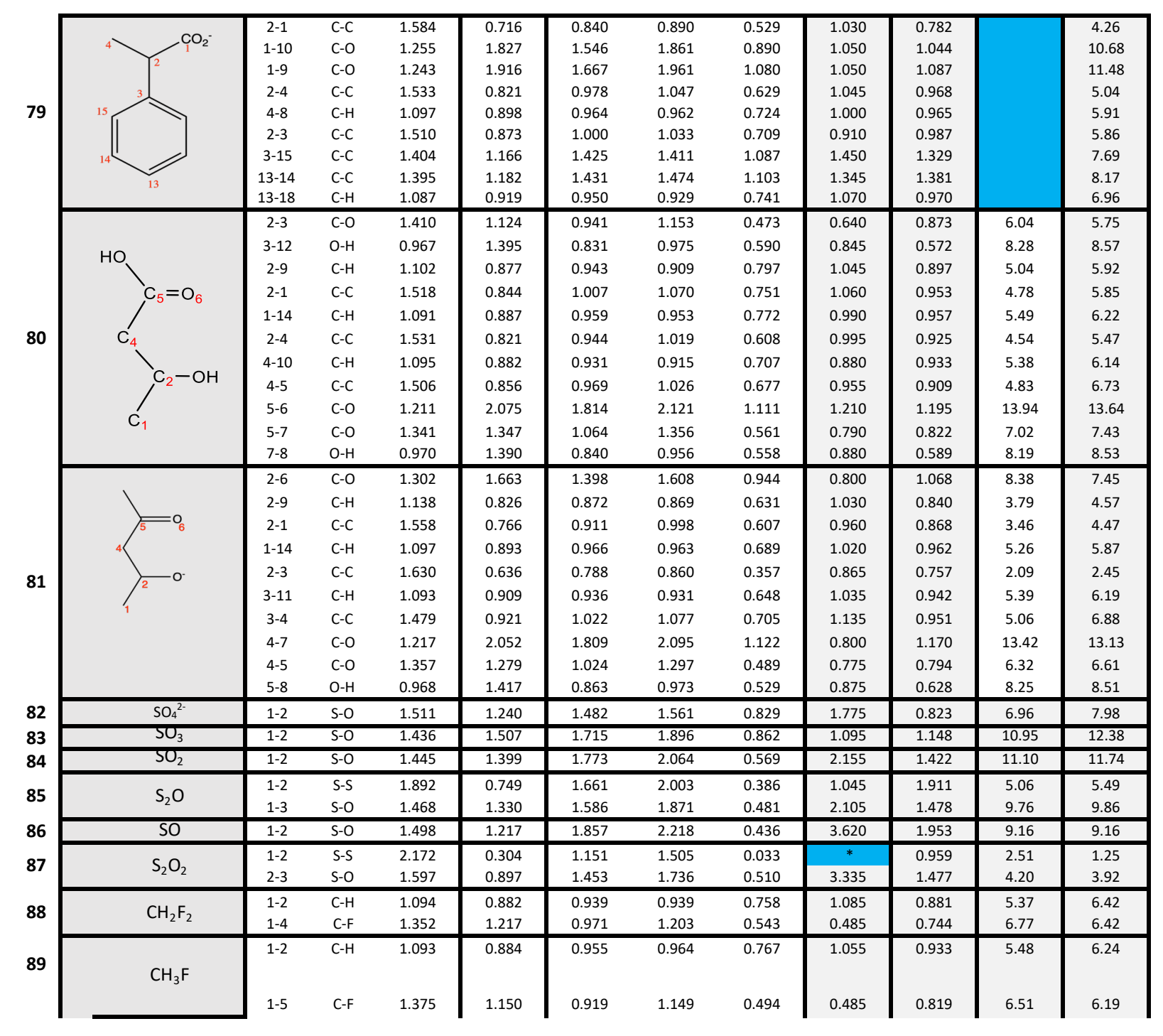




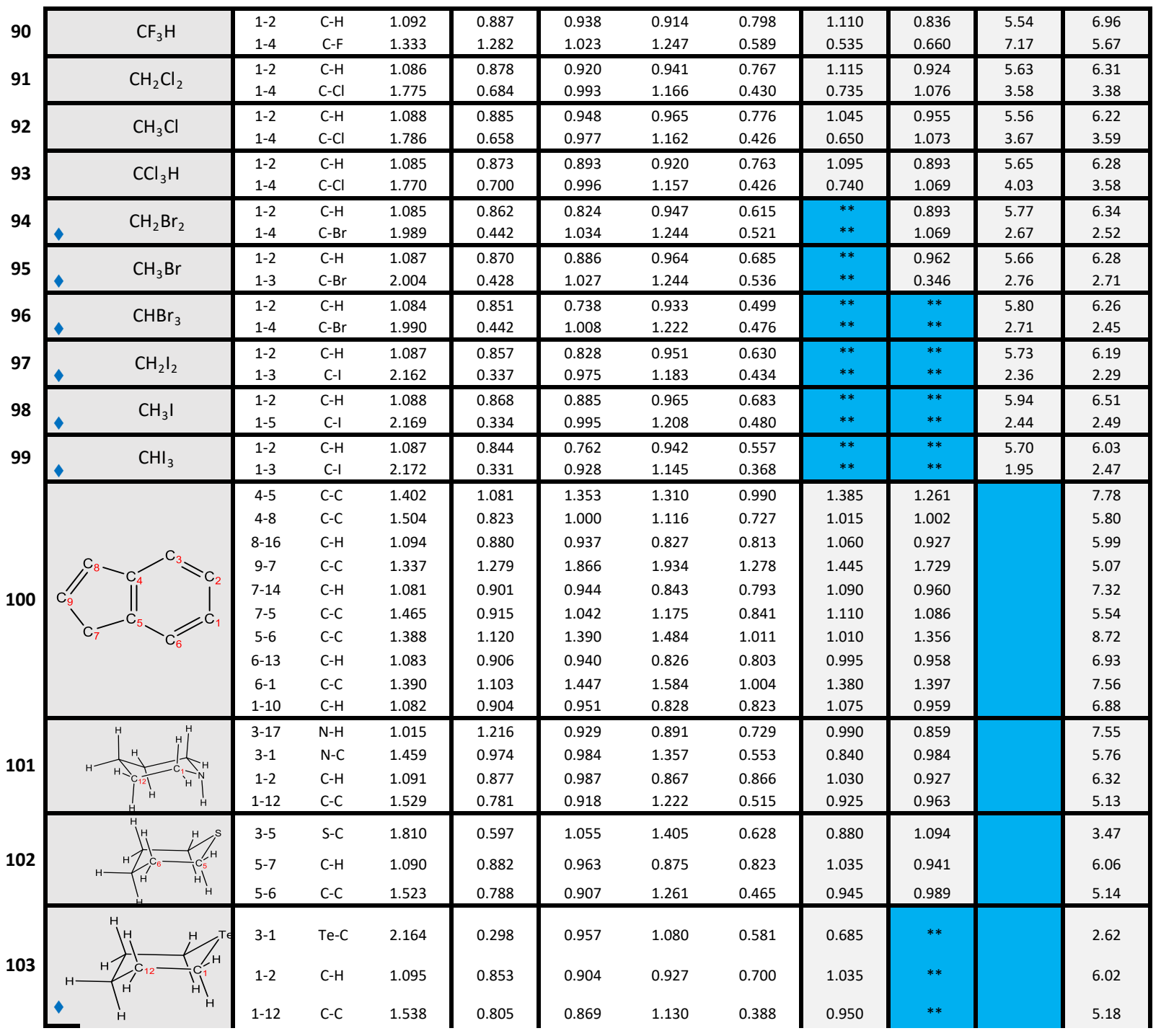




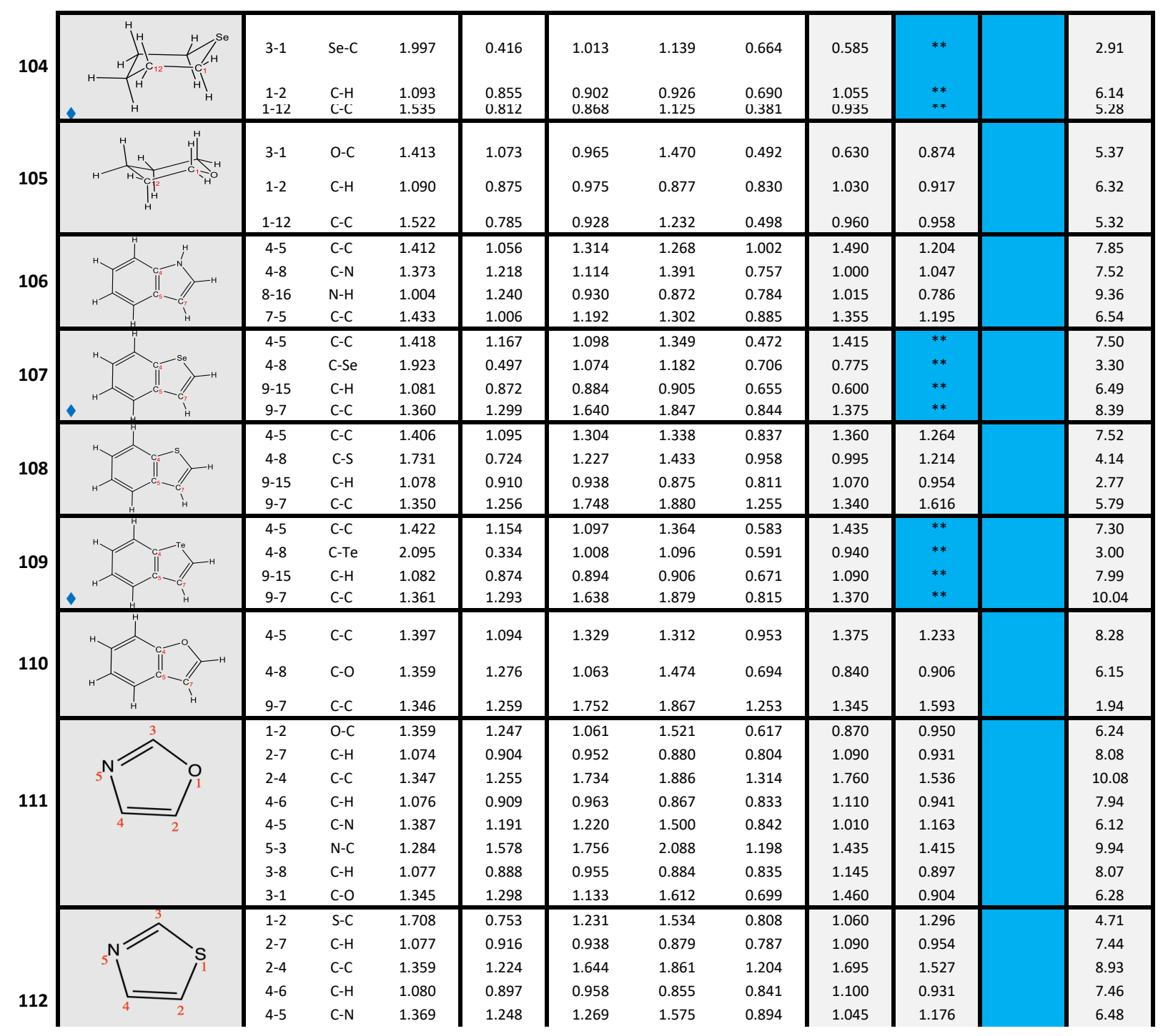




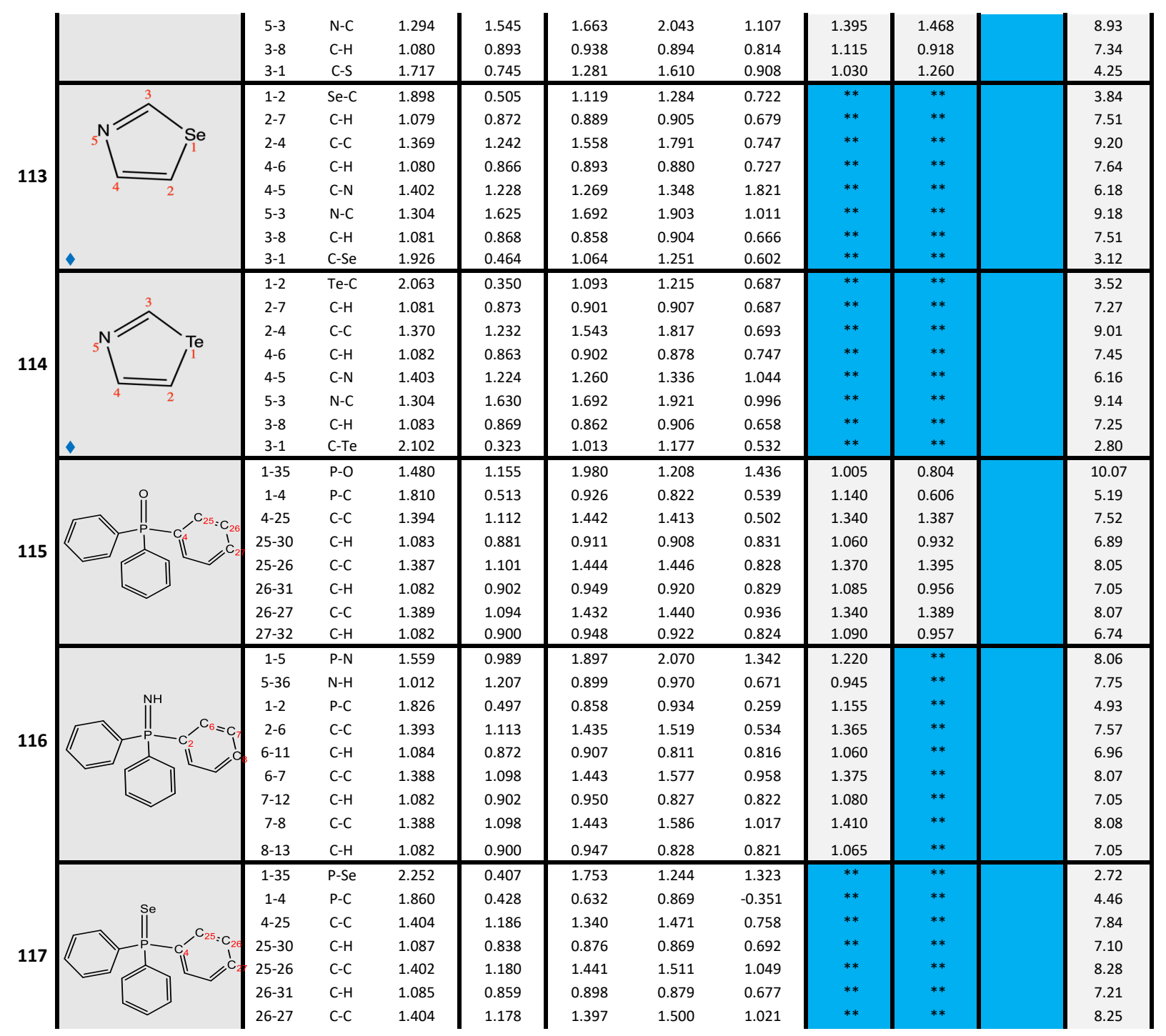




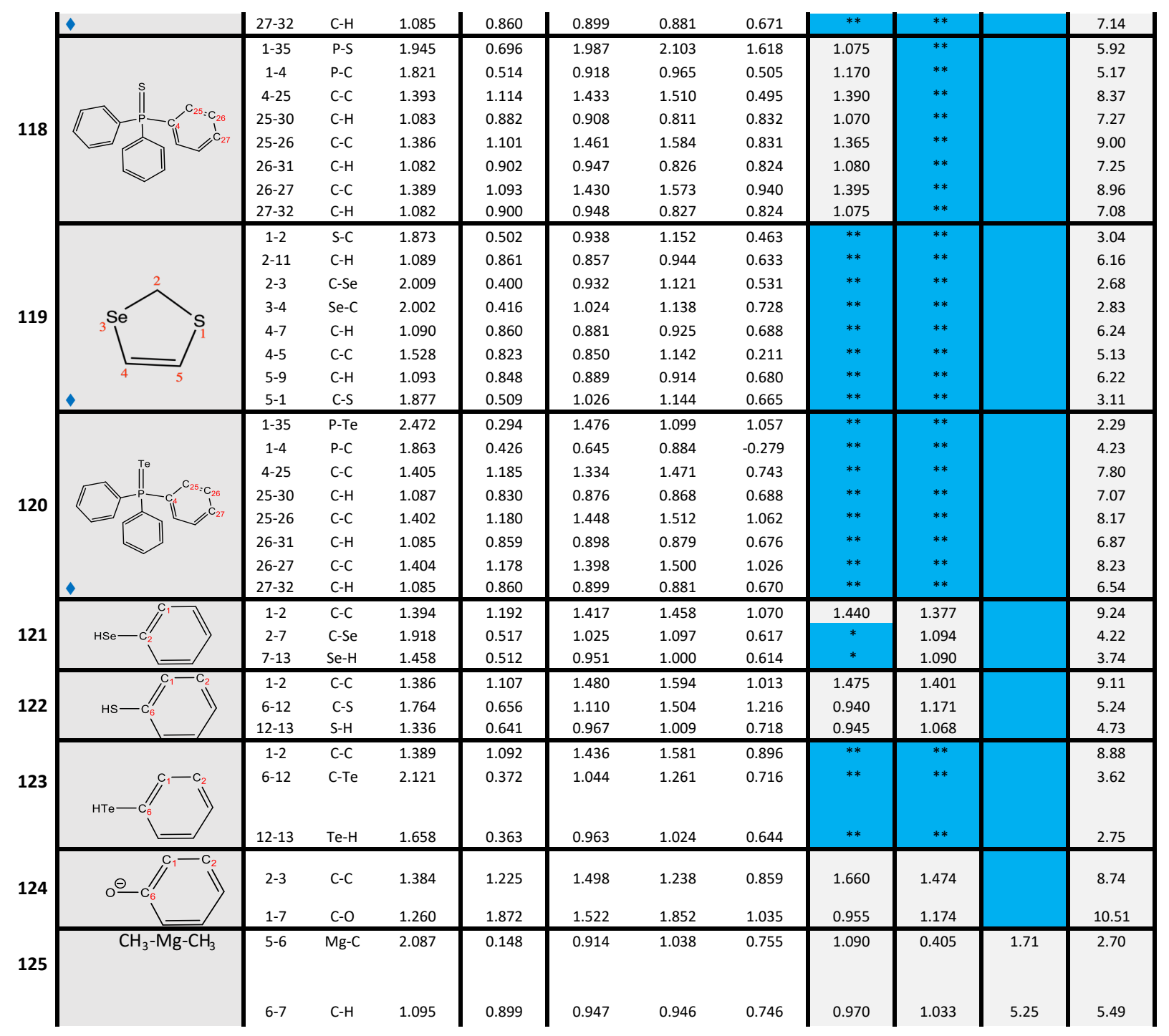




\begin{tabular}{|c|c|c|c|c|c|c|c|c|c|c|c|c|}
\hline 126 & $\mathrm{CH}_{3}-\mathrm{Mg}-\mathrm{Cl}$ & $\begin{array}{l}2-1 \\
1-5 \\
2-3\end{array}$ & $\begin{array}{c}\mathrm{Mg}-\mathrm{C} \\
\mathrm{C}-\mathrm{H} \\
\mathrm{Mg}-\mathrm{Cl}\end{array}$ & $\begin{array}{l}2.068 \\
1.093 \\
2.203\end{array}$ & $\begin{array}{l}0.158 \\
0.898 \\
0.173\end{array}$ & $\begin{array}{l}0.966 \\
0.943 \\
1.099\end{array}$ & $\begin{array}{l}1.088 \\
0.941 \\
1.424\end{array}$ & $\begin{array}{l}0.756 \\
0.751 \\
0.788\end{array}$ & $\begin{array}{l}1.055 \\
0.970 \\
0.670\end{array}$ & $\begin{array}{l}0.450 \\
1.029 \\
0.342\end{array}$ & $\begin{array}{l}1.80 \\
5.31 \\
1.97\end{array}$ & $\begin{array}{l}2.81 \\
5.59 \\
2.38\end{array}$ \\
\hline 127 & $\mathrm{KH}$ & $2-1$ & $\mathrm{H}-\mathrm{K}$ & 2.269 & 0.059 & 0.893 & 0.950 & 0.583 & $*$ & 0.488 & 0.61 & 0.61 \\
\hline 128 & $\mathrm{LiH}$ & $2-1$ & $\mathrm{H}-\mathrm{Li}$ & 1.614 & 0.056 & 0.981 & 1.007 & 0.790 & $*$ & 0.228 & 1.05 & 1.05 \\
\hline 129 & $\mathrm{NaH}$ & $2-1$ & $\mathrm{H}-\mathrm{Na}$ & 1.876 & 0.067 & 0.960 & 1.006 & 0.703 & 0.995 & 0.465 & 0.83 & 0.83 \\
\hline 130 & $\mathrm{CH}_{3}-\mathrm{AlH}_{2}$ & $\begin{array}{l}5-7 \\
5-1\end{array}$ & $\begin{array}{l}\mathrm{Al}-\mathrm{H} \\
\mathrm{Al}-\mathrm{C}\end{array}$ & $\begin{array}{l}1.584 \\
1.954\end{array}$ & $\begin{array}{l}0.210 \\
0.264\end{array}$ & $\begin{array}{l}0.944 \\
0.944\end{array}$ & $\begin{array}{l}0.961 \\
1.042\end{array}$ & $\begin{array}{l}0.795 \\
0.783\end{array}$ & $\begin{array}{l}1.025 \\
1.070 \\
0.970\end{array}$ & $\begin{array}{l}0.427 \\
0.414\end{array}$ & $\begin{array}{l}2.16 \\
2.46\end{array}$ & $\begin{array}{l}2.50 \\
3.44\end{array}$ \\
\hline 131 & $\mathrm{CH}_{3}-\mathrm{Be}-\mathrm{Cl}$ & $\begin{array}{l}5-6 \\
5-1 \\
1-2\end{array}$ & $\begin{array}{c}\mathrm{Be}-\mathrm{Cl} \\
\mathrm{Be}-\mathrm{C} \\
\mathrm{C}-\mathrm{H}\end{array}$ & $\begin{array}{l}1.808 \\
1.674 \\
0.792\end{array}$ & $\begin{array}{l}0.365 \\
0.296 \\
1.234\end{array}$ & $\begin{array}{l}1.219 \\
1.035 \\
0.947\end{array}$ & $\begin{array}{l}1.651 \\
1.151 \\
0.933\end{array}$ & $\begin{array}{l}0.878 \\
0.873 \\
0.762\end{array}$ & $\begin{array}{l}1.160 \\
1.080 \\
0.970\end{array}$ & $\begin{array}{l}0.291 \\
0.289 \\
1.024\end{array}$ & $\begin{array}{l}3.15 \\
2.82 \\
5.38 \\
\end{array}$ & $\begin{array}{l}3.79 \\
4.21 \\
5.70 \\
\end{array}$ \\
\hline 132 & $\mathrm{CH}_{3}-\mathrm{BH}_{2}$ & $\begin{array}{l}5-7 \\
5-1 \\
1-2 \\
\end{array}$ & $\begin{array}{l}\text { B-H } \\
\text { B-C } \\
\text { C-H }\end{array}$ & $\begin{array}{l}1.194 \\
1.559 \\
1.104\end{array}$ & $\begin{array}{l}0.524 \\
0.607 \\
0.874\end{array}$ & $\begin{array}{l}0.984 \\
1.053 \\
0.929\end{array}$ & $\begin{array}{l}0.977 \\
1.176 \\
0.911\end{array}$ & $\begin{array}{l}0.825 \\
0.855 \\
0.733\end{array}$ & $\begin{array}{l}0.995 \\
1.070 \\
0.950\end{array}$ & $\begin{array}{l}0.527 \\
0.511 \\
0.997\end{array}$ & $\begin{array}{l}3.92 \\
4.08 \\
5.11\end{array}$ & $\begin{array}{l}4.55 \\
5.29 \\
5.31\end{array}$ \\
\hline 133 & $\mathrm{CH}_{3}-\mathrm{Li}$ & $\begin{array}{l}5-1 \\
1-2\end{array}$ & $\begin{array}{l}\mathrm{Li}-\mathrm{C} \\
\mathrm{C}-\mathrm{H}\end{array}$ & $\begin{array}{l}1.973 \\
1.098\end{array}$ & $\begin{array}{l}0.089 \\
0.901\end{array}$ & $\begin{array}{l}0.906 \\
0.951\end{array}$ & $\begin{array}{l}1.067 \\
0.943\end{array}$ & $\begin{array}{l}0.741 \\
0.746\end{array}$ & $\begin{array}{l}1.045 \\
0.970\end{array}$ & $\begin{array}{l}0.223 \\
1.053\end{array}$ & $\begin{array}{l}1.21 \\
5.13\end{array}$ & $\begin{array}{l}1.78 \\
5.29\end{array}$ \\
\hline 134 & $\mathrm{CH}_{3}-\mathrm{Mg}-\mathrm{H}$ & $\begin{array}{l}5-6 \\
5-1 \\
1-2\end{array}$ & $\begin{array}{c}\mathrm{Mg}-\mathrm{H} \\
\mathrm{Mg}-\mathrm{C} \\
\mathrm{C}-\mathrm{H}\end{array}$ & $\begin{array}{l}1.707 \\
2.082 \\
1.094\end{array}$ & $\begin{array}{l}0.111 \\
0.147 \\
0.899\end{array}$ & $\begin{array}{l}0.951 \\
0.916 \\
0.947\end{array}$ & $\begin{array}{l}0.952 \\
1.046 \\
0.949\end{array}$ & $\begin{array}{l}0.789 \\
0.751 \\
0.742\end{array}$ & $\begin{array}{l}1.010 \\
1.065 \\
0.975\end{array}$ & $\begin{array}{l}0.441 \\
0.413 \\
1.033\end{array}$ & $\begin{array}{l}1.50 \\
1.74 \\
5.29\end{array}$ & $\begin{array}{l}1.89 \\
2.69 \\
5.56\end{array}$ \\
\hline 135 & $\mathrm{CH}_{3}-\mathrm{PH}_{2}$ & $\begin{array}{l}5-6 \\
5-1 \\
1-2 \\
\end{array}$ & $\begin{array}{l}\text { P-H } \\
\text { P-C } \\
\text { C-H }\end{array}$ & $\begin{array}{l}1.418 \\
1.865 \\
1.090\end{array}$ & $\begin{array}{l}0.491 \\
0.497 \\
0.893\end{array}$ & $\begin{array}{l}0.963 \\
0.981 \\
0.957\end{array}$ & $\begin{array}{l}0.994 \\
1.104 \\
0.968\end{array}$ & $\begin{array}{l}0.674 \\
0.622 \\
0.775\end{array}$ & $\begin{array}{l}1.010 \\
0.920 \\
1.010\end{array}$ & $\begin{array}{l}0.847 \\
0.849 \\
0.987\end{array}$ & $\begin{array}{l}3.34 \\
3.04 \\
5.52\end{array}$ & $\begin{array}{l}3.51 \\
3.46 \\
6.12 \\
\end{array}$ \\
\hline 136 & $\mathrm{CH}_{3}-\mathrm{K}$ & $\begin{array}{l}2-1 \\
1-3\end{array}$ & $\begin{array}{l}\mathrm{K}-\mathrm{C} \\
\mathrm{C}-\mathrm{H}\end{array}$ & $\begin{array}{l}2.694 \\
1.098\end{array}$ & $\begin{array}{l}0.062 \\
0.907\end{array}$ & $\begin{array}{l}0.745 \\
0.994\end{array}$ & $\begin{array}{l}0.806 \\
0.990\end{array}$ & $\begin{array}{l}0.473 \\
0.740\end{array}$ & $\begin{array}{c}* \\
0.995\end{array}$ & $\begin{array}{l}0.442 \\
1.045\end{array}$ & $\begin{array}{l}0.66 \\
5.24\end{array}$ & $\begin{array}{l}1.16 \\
5.41\end{array}$ \\
\hline 137 & $\mathrm{Si}\left(\mathrm{CH}_{3}\right)_{4}$ & $\begin{array}{c}1-3 \\
3-12\end{array}$ & $\begin{array}{l}\mathrm{Si}-\mathrm{C} \\
\mathrm{C}-\mathrm{H}\end{array}$ & $\begin{array}{l}1.884 \\
1.094\end{array}$ & $\begin{array}{l}0.392 \\
0.894\end{array}$ & $\begin{array}{l}0.952 \\
0.951\end{array}$ & $\begin{array}{l}1.002 \\
0.955\end{array}$ & $\begin{array}{l}0.784 \\
0.754\end{array}$ & $\begin{array}{l}1.025 \\
0.990\end{array}$ & $\begin{array}{l}0.436 \\
1.002\end{array}$ & $\begin{array}{l}2.99 \\
5.39\end{array}$ & $\begin{array}{l}4.18 \\
5.85\end{array}$ \\
\hline 138 & $\mathrm{CH}_{3}-\mathrm{Na}$ & $\begin{array}{l}2-1 \\
1-3 \\
\end{array}$ & $\begin{array}{l}\mathrm{Na}-\mathrm{C} \\
\mathrm{C}-\mathrm{H}\end{array}$ & $\begin{array}{l}2.279 \\
1.095\end{array}$ & $\begin{array}{l}0.086 \\
0.909\end{array}$ & $\begin{array}{l}1.044 \\
0.965\end{array}$ & $\begin{array}{l}1.044 \\
0.965\end{array}$ & $\begin{array}{l}0.603 \\
0.754\end{array}$ & $\begin{array}{l}1.010 \\
0.990\end{array}$ & $\begin{array}{l}0.474 \\
1.041\end{array}$ & $\begin{array}{l}0.94 \\
5.35\end{array}$ & $\begin{array}{l}1.44 \\
5.58\end{array}$ \\
\hline 139 & $\mathrm{KCl}$ & $1-2$ & $\mathrm{~K}-\mathrm{Cl}$ & 2.687 & 0.076 & 0.346 & 0.732 & 0.171 & $*$ & 0.332 & 0.98 & 0.98 \\
\hline 140 & $\mathrm{KF}$ & $1-2$ & K-F & 2.141 & 0.151 & 0.468 & 0.746 & 0.207 & $*$ & 0.405 & 1.87 & 1.87 \\
\hline 141 & $\mathrm{LiCl}$ & $1-2$ & $\mathrm{Li}-\mathrm{Cl}$ & 2.054 & 0.108 & 0.998 & 1.457 & 0.728 & * & 0.169 & 1.42 & 1.42 \\
\hline 142 & $\mathrm{LiF}$ & $1-2$ & $\mathrm{Li}-\mathrm{F}$ & 1.550 & 0.182 & 0.792 & 1.239 & 0.506 & 1.240 & 0.195 & 3.21 & 3.21 \\
\hline 143 & $\mathrm{NaCl}$ & $1-2$ & $\mathrm{Na}-\mathrm{Cl}$ & 2.362 & 0.091 & 0.750 & 1.189 & 0.539 & 4.065 & 0.266 & 1.11 & 1.11 \\
\hline 144 & $\mathrm{NaF}$ & $1-2$ & $\mathrm{Na}-\mathrm{F}$ & 1.876 & 0.139 & 0.729 & 1.056 & 0.433 & 4.180 & 0.294 & 2.17 & 2.17 \\
\hline 145 & $\mathrm{HBr}$ & $1-2$ & $\mathrm{H}-\mathrm{Br}$ & 1.420 & 0.501 & 0.985 & 1.160 & 0.598 & $*$ & 1.117 & 3.53 & 3.53 \\
\hline 146 & $\mathrm{HCl}$ & $1-2$ & $\mathrm{H}-\mathrm{Cl}$ & 1.280 & 0.817 & 0.991 & 1.208 & 0.637 & 0.915 & 1.015 & 5.18 & 5.18 \\
\hline 147 & $\mathrm{HF}$ & $1-2$ & $\mathrm{H}-\mathrm{F}$ & 0.921 & 1.628 & 0.956 & 1.310 & 0.561 & 0.640 & 0.497 & 10.26 & 10.26 \\
\hline 148 & $\mathrm{HI}$ & $1-2$ & $\mathrm{H}-\mathrm{I}$ & 1.633 & 0.353 & 0.975 & 1.017 & 0.531 & $* *$ & $* *$ & 2.87 & 2.87 \\
\hline
\end{tabular}




\begin{tabular}{|c|c|c|c|c|c|c|c|c|c|c|c|c|}
\hline \multirow{3}{*}{149} & \multirow[t]{3}{*}{$\mathrm{HH}$} & $1-2$ & $C-N$ & 1.462 & 0.976 & 0.887 & 1.126 & 0.452 & 1.040 & 0.892 & 4.97 & 5.25 \\
\hline & & $1-3$ & $\mathrm{C}-\mathrm{H}$ & 1.089 & 0.885 & 0.946 & 0.945 & 0.759 & 1.000 & 0.931 & 5.59 & 6.47 \\
\hline & & $2-6$ & $\mathrm{~N}-\mathrm{F}$ & 1.389 & 1.167 & 0.889 & 1.169 & 0.196 & 0.325 & 1.061 & 5.32 & 5.08 \\
\hline \multirow{4}{*}{150} & \multirow{4}{*}{$\sum_{H}^{H} N_{i}^{H}$} & $1-2$ & C-N & 1.456 & 1.011 & 0.946 & 1.159 & 0.544 & 0.875 & 0.960 & 5.29 & 5.54 \\
\hline & & $1-3$ & $\mathrm{C}-\mathrm{H}$ & 1.091 & 0.881 & 0.955 & 0.955 & 0.789 & 1.005 & 0.936 & 5.45 & 6.32 \\
\hline & & $2-6$ & $\mathrm{~N}-\mathrm{H}$ & 1.021 & 1.162 & 0.881 & 0.960 & 0.656 & 1.040 & 0.818 & 6.75 & 7.33 \\
\hline & & $2-7$ & $\mathrm{~N}-\mathrm{F}$ & 1.413 & 1.097 & 0.866 & 1.121 & 0.211 & 0.275 & 1.094 & 5.66 & 5.23 \\
\hline \multirow{3}{*}{151} & \multirow{3}{*}{$\mathrm{H}^{\mathrm{H}} \mathrm{NH}_{2}$} & $1-2$ & C-N & 1.460 & 1.019 & 0.979 & 1.170 & 0.593 & 0.825 & 1.016 & 5.54 & 5.78 \\
\hline & & $1-3$ & $\mathrm{C}-\mathrm{H}$ & 1.093 & 0.884 & 0.967 & 0.962 & 0.797 & 1.025 & 0.945 & 5.40 & 6.15 \\
\hline & & $2-6$ & $\mathrm{~N}-\mathrm{H}$ & 1.015 & 1.210 & 0.910 & 0.983 & 0.699 & 0.995 & 0.867 & 7.13 & 7.63 \\
\hline \multirow[t]{3}{*}{152} & \multirow[b]{2}{*}{$\mathrm{Mo}_{2}$} & & & & & & & & & & & \\
\hline & & $1-2$ & Mo-Mo & 1.937 & 0.945 & 5.997 & 7.028 & 1.814 & $* *$ & $* *$ & 10.65 & 10.65 \\
\hline & \multirow{4}{*}{$\mathrm{H}_{2} \mathrm{C}=\mathrm{C}=\mathrm{CH}_{2}$} & $2-1$ & C-C & 1.305 & 1.561 & 1.977 & 2.046 & 1.244 & 1.875 & 1.897 & 11.09 & 14.06 \\
\hline \multirow{3}{*}{153} & & $1-4$ & $\mathrm{C}-\mathrm{H}$ & 1.085 & 0.900 & 0.922 & 0.927 & 0.725 & 1.045 & 0.950 & 5.84 & 6.83 \\
\hline & & $2-3$ & $C-C$ & 1.305 & 1.561 & 1.977 & 2.041 & 1.244 & 1.940 & 1.897 & 11.09 & 14.06 \\
\hline & & $3-6$ & $\mathrm{C}-\mathrm{H}$ & 1.085 & 0.900 & 0.922 & 0.928 & 0.725 & 1.050 & 0.950 & 5.84 & 6.83 \\
\hline \multirow{2}{*}{154} & \multirow[t]{2}{*}{$\mathrm{NH}_{2}-\mathrm{NH}_{2}$} & $1-2$ & $\mathrm{~N}-\mathrm{N}$ & 1.472 & 1.017 & 0.942 & 1.176 & 0.314 & 0.605 & 1.208 & 5.17 & 4.83 \\
\hline & & $1-3$ & $\mathrm{~N}-\mathrm{H}$ & 1.020 & 1.155 & 0.902 & 0.984 & 0.676 & 1.005 & 0.858 & 6.90 & 7.30 \\
\hline \multirow{3}{*}{155} & \multirow[t]{3}{*}{$\mathrm{HN}_{3}$} & $2-1$ & $\mathrm{~N}-\mathrm{N}$ & 1.239 & 2.148 & 1.443 & 1.831 & 0.685 & 0.430 & 1.695 & 10.96 & 14.19 \\
\hline & & $2-3$ & $\mathrm{~N}-\mathrm{N}$ & 1.128 & 3.040 & 2.269 & 2.774 & 1.185 & 0.665 & 2.446 & 21.24 & 22.53 \\
\hline & & $1-4$ & $\mathrm{~N}-\mathrm{H}$ & 1.021 & 1.169 & 0.833 & 0.916 & 0.630 & 0.380 & 0.750 & 6.91 & 7.35 \\
\hline \multirow{5}{*}{156} & \multirow{5}{*}{$\mathrm{CH}_{2}-\mathrm{BH}-\mathrm{NH}_{3}$} & $2-1$ & B-N & 1.396 & 0.904 & 1.336 & 1.603 & 0.979 & 1.965 & 0.532 & 7.00 & 8.59 \\
\hline & & $2-6$ & B-H & 1.198 & 0.523 & 0.970 & 0.947 & 0.825 & 1.025 & 0.485 & 3.85 & 4.71 \\
\hline & & $2-3$ & B-C & 1.577 & 0.584 & 1.011 & 1.100 & 0.860 & 1.035 & 0.468 & 3.91 & 5.34 \\
\hline & & $1-4$ & $\mathrm{~N}-\mathrm{H}$ & 1.007 & 1.232 & 0.903 & 0.951 & 0.720 & 0.980 & 0.829 & 7.61 & 8.67 \\
\hline & & & $-\pi$ & כנט.1 & 0.500 & 0.965 & 0.959 & 0.160 & 0.980 & 0.998 & 3.36 & \\
\hline 157 & {$\left[\mathrm{HFH}^{+}{ }^{+}\right.$} & $1-2$ & $\mathrm{~F}-\mathrm{H}$ & 0.986 & 1.176 & 0.626 & 0.796 & 0.495 & 0.665 & 0.231 & 5.98 & 7.36 \\
\hline 158 & {$[\mathrm{FHF}]^{-}$} & $1-2$ & $\mathrm{~F}-\mathrm{H}$ & 1.150 & 0.689 & 0.451 & 0.612 & 0.295 & * & 0.269 & 2.52 & 1.29 \\
\hline \multirow{2}{*}{159} & $\mathrm{H}_{2} \mathrm{O}_{2}$ & $1-2$ & $\mathrm{H}-\mathrm{O}$ & 0.967 & 1.392 & 0.856 & 1.007 & 0.562 & 0.830 & 0.632 & 8.26 & 8.54 \\
\hline & & $2-3$ & $0-0$ & 1.427 & 1.086 & 0.942 & 2.274 & 0.637 & 0.295 & 1.283 & 5.85 & 5.33 \\
\hline \multirow{2}{*}{160} & $\mathrm{H}_{3} \mathrm{Si}-\mathrm{F}$ & $1-2$ & $\mathrm{Si}-\mathrm{F}$ & 1.607 & 0.569 & 0.938 & 1.097 & 0.651 & 3.955 & 0.377 & 5.88 & 6.16 \\
\hline & & $1-3$ & $\mathrm{Si}-\mathrm{H}$ & 1.478 & 0.351 & 0.929 & 0.958 & 0.749 & 1.020 & 0.472 & 3.31 & 3.71 \\
\hline 161 & $\mathrm{HO}^{-}$ & $1-2$ & $\mathrm{O}-\mathrm{H}$ & 0.979 & 1.502 & 0.979 & 1.151 & 0.309 & 0.665 & 0.943 & 7.22 & 7.22 \\
\hline 162 & $\mathrm{H}_{3} \mathrm{O}^{+}$ & $1-2$ & $\mathrm{O}-\mathrm{H}$ & 0.981 & 1.268 & 0.766 & 0.914 & 0.599 & 0.915 & 0.451 & 7.47 & 7.47 \\
\hline 163 & $\mathrm{NH}_{2}^{-}$ & $1-2$ & $\mathrm{~N}-\mathrm{H}$ & 1.044 & 1.202 & 0.968 & 1.079 & 0.418 & 0.865 & 1.076 & 5.71 & 5.71 \\
\hline 164 & $\mathrm{NH}_{4}^{+}$ & $1-2$ & $\mathrm{~N}-\mathrm{H}$ & 1.026 & 1.090 & 0.818 & 0.924 & 0.655 & 0.935 & 0.699 & 6.78 & 6.78 \\
\hline & & $1-2$ & $\mathrm{Pt}-\mathrm{Cl}$ & 2.403 & 0.227 & 0.965 & 1.264 & 0.572 & $* *$ & $* *$ & 2.02 & 2.44 \\
\hline 165 & & $1-5$ & Pt-N & 2.108 & 0.286 & 0.388 & 0.770 & 0.053 & $* *$ & $* *$ & 2.08 & 3.05 \\
\hline & & $5-8$ & $\mathrm{~N}-\mathrm{H}$ & 1.021 & 1.095 & 0.820 & 0.887 & 0.622 & $* *$ & $* *$ & 7.17 & 7.82 \\
\hline
\end{tabular}




\begin{tabular}{|c|c|c|c|c|c|c|c|c|c|c|c|c|}
\hline \multirow{4}{*}{166} & \multirow{4}{*}{ 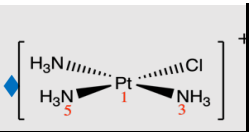 } & $1-2$ & $\mathrm{Pt}-\mathrm{Cl}$ & 2.380 & 0.235 & 1.031 & 1.320 & 0.582 & $* *$ & $* *$ & 2.14 & 2.73 \\
\hline & & $1-5$ & Pt-N & 2.129 & 0.268 & 0.367 & 0.762 & 0.067 & $* *$ & $* *$ & 1.79 & 3.20 \\
\hline & & $5-8$ & $\mathrm{~N}-\mathrm{H}$ & 1.024 & 1.074 & 0.811 & 0.887 & 0.632 & $* *$ & $* *$ & 7.01 & 7.63 \\
\hline & & $1-3$ & Pt-N & 2.090 & 0.301 & 0.458 & 0.808 & 0.160 & $* *$ & $* *$ & 2.25 & 3.41 \\
\hline \multirow{4}{*}{167} & \multirow{4}{*}{ 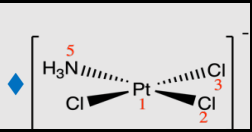 } & $1-2$ & $\mathrm{Pt}-\mathrm{Cl}$ & 2.405 & 0.229 & 0.958 & 1.287 & 0.571 & $* *$ & $* *$ & 1.78 & 2.27 \\
\hline & & $1-3$ & $\mathrm{Pt}-\mathrm{Cl}$ & 2.451 & 0.205 & 0.848 & 1.184 & 0.485 & $* *$ & $* *$ & 1.50 & 1.85 \\
\hline & & $1-5$ & Pt-N & 2.088 & 0.296 & 0.318 & 0.766 & 0.007 & $* *$ & $* *$ & 2.16 & 2.81 \\
\hline & & $5-8$ & $\mathrm{~N}-\mathrm{H}$ & 1.023 & 1.073 & 0.797 & 0.871 & 0.575 & $* *$ & $* *$ & 7.22 & 7.87 \\
\hline \multirow{2}{*}{168} & \multirow{2}{*}[\mathrm{Pt}(\mathrm{NH}_{3})_{4}]{$^{2+}$} & $1-2$ & Pt-N & 2.109 & 0.289 & 0.474 & 0.814 & 0.205 & $* *$ & $* *$ & 0.53 & 2.61 \\
\hline & & 2-16 & $\mathrm{N}-\mathrm{H}$ & 1.028 & 1.049 & 0.785 & 0.882 & 0.624 & $* *$ & $* *$ & 6.86 & 7.35 \\
\hline \multirow{2}{*}{$\begin{array}{l}169 \\
170\end{array}$} & \multirow{3}{*}{$\begin{array}{c}\mathrm{N}_{2} \\
\mathrm{C}_{2} \\
\mathrm{Cr}_{2}\end{array}$} & $1-2$ & $\mathrm{~N}-\mathrm{N}$ & 1.099 & 3.041 & 2.752 & 3.432 & 1.135 & 1.385 & 3.040 & 26.71 & 26.71 \\
\hline & & $1-2$ & $\mathrm{C}-\mathrm{C}$ & 1.251 & 2.057 & 3.419 & 3.654 & 1.641 & 3.945 & $*$ & 13.24 & 13.24 \\
\hline \multirow{2}{*}{$\begin{array}{l}171 \\
172\end{array}$} & & $1-2$ & $\mathrm{Cr}-\mathrm{Cr}$ & 1.665 & 1.176 & 4.052 & 4.592 & 1.414 & $*$ & $*$ & 4.86 & 4.86 \\
\hline & $\quad W_{2}$ & $1-2$ & W-W & 2.145 & 0.617 & 4.179 & 5.846 & 0.138 & ${ }^{*}$ & ${ }^{*}$ & 7.65 & 7.65 \\
\hline \multirow{3}{*}{$\begin{array}{l}173 \\
174 \\
175\end{array}$} & $\mathrm{~F}_{2}$ & $1-2$ & $\mathrm{~F}-\mathrm{F}$ & 1.374 & 1.133 & 0.989 & 1.277 & 0.131 & 0.410 & 1.274 & 7.62 & 7.62 \\
\hline & $\mathrm{CT}_{2}$ & $1-2$ & $\mathrm{Cl}-\mathrm{Cl}$ & 2.011 & 0.494 & 0.933 & 1.208 & 0.051 & ${ }^{*}$ & 1.330 & 3.17 & 3.17 \\
\hline & $\mathrm{Br}_{2}$ & $1-2$ & $\mathrm{Br}-\mathrm{Br}$ & 2.476 & 0.206 & 0.980 & 1.102 & 0.222 & $* *$ & 1.215 & 1.96 & 1.96 \\
\hline \multirow{2}{*}{176} & $T_{2}$ & $1-2$ & $1-1$ & 2.827 & 0.146 & 0.968 & 1.093 & 0.201 & $* *$ & 1.216 & 1.40 & 1.40 \\
\hline & $\mathrm{B}_{2} \mathrm{H}_{6}$ & $1-2$ & B-H & 1.187 & 0.552 & 0.982 & 0.961 & 0.840 & 1.005 & 0.549 & & 4.64 \\
\hline \multirow[t]{2}{*}{177} & & $1-3$ & B-H & 1.314 & 0.469 & 0.479 & 0.479 & 0.407 & 1.005 & 0.315 & & 2.36 \\
\hline & & $1-4$ & B-B & 1.762 & 0.472 & 0.557 & 0.843 & 0.321 & 1.920 & $*$ & & 3.52 \\
\hline \multirow{2}{*}{178} & & $2-1$ & $\mathrm{C}-\mathrm{C}$ & 1.515 & 0.841 & 0.995 & 1.076 & 0.727 & 0.980 & 0.956 & 4.73 & 5.73 \\
\hline & & $1-3$ & $\mathrm{C}-\mathrm{C}$ & 1.526 & 0.822 & 0.984 & 1.079 & 0.613 & 0.925 & 0.995 & 4.67 & 5.55 \\
\hline \multirow{3}{*}{179} & & $4-3$ & $\mathrm{C}-\mathrm{C}$ & 1.514 & 0.841 & 0.995 & 1.074 & 0.717 & 1.000 & 0.955 & 4.72 & 5.75 \\
\hline & & $3-1$ & $\mathrm{C}-\mathrm{C}$ & 1.527 & 0.823 & 0.977 & 1.057 & 0.629 & 0.905 & 0.978 & 4.59 & 5.47 \\
\hline & & $1-2$ & $\mathrm{C}-\mathrm{C}$ & 1.526 & 0.824 & 1.002 & 1.087 & 0.712 & 0.945 & 0.995 & 4.68 & 5.53 \\
\hline \multirow{4}{*}{180} & & $1-2$ & $\mathrm{C}-\mathrm{C}$ & 1.514 & 0.839 & 0.992 & 1.077 & 0.700 & 0.960 & 0.958 & 4.76 & 5.74 \\
\hline & & $1-3$ & C-C & 1.526 & 0.824 & 0.989 & 1.059 & 0.693 & 0.930 & 0.946 & 4.63 & 5.50 \\
\hline & & $3-4$ & $C-C$ & 1.526 & 0.827 & 0.996 & 1.064 & 0.745 & 0.920 & 0.976 & 4.63 & 5.51 \\
\hline & & 4-12 & $C-C$ & 1.526 & 0.825 & 1.003 & 1.088 & 0.726 & 0.935 & 0.995 & 4.67 & 5.53 \\
\hline \multirow{2}{*}{181} & $\mathrm{C}_{3} \mathrm{H}_{8}$ & $2-1$ & C-C & 1.527 & 0.825 & 1.004 & 1.091 & 0.736 & 0.940 & 0.995 & 4.66 & 5.50 \\
\hline & & $1-3$ & $\mathrm{C}-\mathrm{C}$ & 1.527 & 0.825 & 1.004 & 1.090 & 0.736 & 0.905 & 0.995 & 4.66 & 5.50 \\
\hline \multirow{3}{*}{182} & \multirow{3}{*}{$\mathrm{C}_{4} \mathrm{H}_{3}-\mathrm{C}_{3} \mathrm{H}_{2}-\mathrm{C}_{1} \mathrm{H}_{2}-\mathrm{C}_{2} \mathrm{H}$} & $4-3$ & C-C & 1.526 & 0.824 & 1.003 & 1.088 & 0.725 & 0.940 & 0.995 & 4.66 & 5.53 \\
\hline & & $3-1$ & $\mathrm{C}-\mathrm{C}$ & 1.528 & 0.826 & 0.997 & 1.066 & 0.757 & 0.960 & 0.978 & 4.61 & 5.43 \\
\hline & & $1-2$ & C-C & 1.526 & 0.824 & 1.003 & 1.088 & 0.725 & 0.925 & 0.995 & 4.67 & 5.53 \\
\hline \multirow{4}{*}{183} & $\mathrm{C}_{5} \mathrm{H}_{12}$ & $1-2$ & C-C & 1.526 & 0.824 & 1.002 & 1.088 & 0.720 & 0.920 & 0.995 & 4.66 & 5.53 \\
\hline & & $2-3$ & C-C & 1.527 & 0.826 & 0.997 & 1.064 & 0.748 & 0.930 & 0.978 & 4.61 & 5.48 \\
\hline & & $3-4$ & C-C & 1.527 & 0.826 & 0.997 & 1.064 & 0.748 & 0.930 & 0.978 & 4.61 & 5.48 \\
\hline & & $4-5$ & $\mathrm{C}-\mathrm{C}$ & 1.526 & 0.824 & 1.002 & 1.088 & 0.720 & 0.920 & 0.915 & 4.66 & 5.52 \\
\hline & $\mathrm{C}_{6} \mathrm{H}_{14}$ & $1-2$ & $C-C$ & 1.527 & 0.823 & 1.002 & 1.088 & 0.718 & 0.930 & 0.995 & 4.65 & 6.07 \\
\hline & & $2-3$ & C-C & 1.527 & 0.825 & 0.951 & 1.063 & 0.743 & 0.920 & 0.978 & 4.60 & 5.99 \\
\hline 184 & & $3-4$ & $C-C$ & 1.527 & 0.824 & 0.997 & 1.062 & 0.741 & 0.905 & 0.978 & 4.60 & 5.49 \\
\hline & & $4-5$ & C-C & 1.527 & 0.825 & 0.995 & 1.088 & 0.743 & 0.915 & 0.978 & 4.60 & 5.99 \\
\hline
\end{tabular}




\begin{tabular}{|c|c|c|c|c|c|c|c|c|c|c|c|c|}
\hline & & $5-6$ & C-C & 1.527 & 0.823 & 1.001 & 1.063 & 0.718 & 0.955 & 0.949 & 4.65 & 6.07 \\
\hline \multirow{2}{*}{185} & & $2-1$ & $\mathrm{C}-\mathrm{C}$ & 1.517 & 0.835 & 1.001 & 1.069 & 0.752 & 0.955 & 0.952 & 4.76 & 5.76 \\
\hline & & $1-3$ & C-C & 1.525 & 0.825 & 0.994 & 1.083 & 0.672 & 0.900 & 0.996 & 4.69 & 5.59 \\
\hline \multirow{3}{*}{186} & & $4-3$ & C-C & 1.517 & 0.834 & 1.001 & 1.066 & 0.740 & 0.975 & 0.952 & 4.76 & 5.78 \\
\hline & & $3-1$ & $C-C$ & 1.526 & 0.826 & 0.987 & 1.060 & 0.691 & 0.940 & 0.979 & 4.63 & 5.54 \\
\hline & & $1-2$ & C-C & 1.526 & 0.825 & 1.004 & 1.087 & 0.727 & 0.920 & 0.995 & 4.68 & 5.53 \\
\hline \multirow{4}{*}{187} & & $12-4$ & C-C & 1.518 & 0.832 & 1.002 & 1.069 & 0.734 & 0.965 & 0.954 & 4.79 & 5.75 \\
\hline & & $4-3$ & C-C & 1.526 & 0.824 & 0.993 & 1.060 & 0.717 & 0.935 & 0.975 & 4.63 & 5.50 \\
\hline & & $3-1$ & $C-C$ & 1.527 & 0.827 & 0.997 & 1.064 & 0.752 & 0.925 & 0.979 & 4.62 & 5.50 \\
\hline & & $1-2$ & C-C & 1.526 & 0.824 & 1.003 & 1.088 & 0.724 & 0.930 & 0.995 & 4.66 & 5.52 \\
\hline \multirow{5}{*}{188} & & $2-1$ & C-C & 1.517 & 0.834 & 0.999 & 1.066 & 0.731 & 0.965 & 0.952 & 4.62 & 4.07 \\
\hline & & $1-3$ & C-C & 1.526 & 0.825 & 0.985 & 1.057 & 0.674 & 0.920 & 0.979 & 4.51 & 5.07 \\
\hline & & $3-4$ & C-C & 1.527 & 0.825 & 0.998 & 1.062 & 0.742 & 0.945 & 0.977 & 4.49 & 5.31 \\
\hline & & $4-12$ & C-C & 1.527 & 0.826 & 0.995 & 1.063 & 0.742 & 0.935 & 0.978 & 4.49 & 5.42 \\
\hline & & $12-15$ & $C-C$ & 1.526 & 0.824 & 1.002 & 1.088 & 0.719 & 0.905 & 0.995 & 4.54 & 5.49 \\
\hline 189 & $\mathrm{H}_{2} \mathrm{~S}$ & $1-2$ & $\mathrm{~S}-\mathrm{H}$ & 1.340 & 0.663 & 0.971 & 1.033 & 0.587 & 0.940 & 1.108 & 4.40 & 4.40 \\
\hline 190 & $\mathrm{H}_{2} \mathrm{Se}$ & $1-2$ & $\mathrm{Se}-\mathrm{H}$ & 1.479 & 0.477 & 0.955 & 0.989 & 0.617 & $* *$ & 1.092 & 3.64 & 3.64 \\
\hline 191 & $\mathrm{H}_{2} \mathrm{Te}$ & $1-2$ & Te-H & 1.668 & 0.284 & 0.959 & 1.008 & 0.564 & $* *$ & $* *$ & 2.59 & 2.59 \\
\hline \multirow{3}{*}{192} & & $1-5$ & Pt-S & 2.424 & 0.231 & 0.927 & 1.226 & 0.566 & $* *$ & $* *$ & 1.61 & 1.88 \\
\hline & $\Delta \mathrm{MeS} \lll \ldots$ & $1-3$ & $\mathrm{Pt}-\mathrm{Cl}$ & 2.470 & 0.200 & 0.802 & 1.143 & 0.464 & $* *$ & $* *$ & 1.26 & 1.61 \\
\hline & & $1-2$ & $\mathrm{Pt}-\mathrm{Cl}$ & 2.513 & 0.180 & 0.750 & 1.091 & 0.456 & $* *$ & $* *$ & 1.06 & 1.40 \\
\hline \multirow{2}{*}{193} & $\quad\left[\text { cis- } \mathrm{Pt}\left(\mathrm{SCH}_{3}\right)_{2} \mathrm{Cl}_{2}\right]^{2-}$ & $1-3$ & $\mathrm{Pt}-\mathrm{Cl}$ & 2.512 & 0.182 & 0.762 & 1.090 & 0.467 & $* *$ & $* *$ & 1.07 & 1.41 \\
\hline & & $1-4$ & Pt-S & 2.429 & 0.229 & 0.894 & 1.168 & 0.554 & $* *$ & $* *$ & 1.52 & 1.79 \\
\hline \multirow{2}{*}{194} & {$\left[\text { trans- } \mathrm{Pt}\left(\mathrm{SCH}_{3}\right)_{2} \mathrm{Cl}_{2}\right]^{2-}$} & $1-2$ & $\mathrm{Pt}-\mathrm{Cl}$ & 2.479 & 0.196 & 0.766 & 1.103 & 0.452 & $* *$ & ** & 1.20 & 1.60 \\
\hline & & $1-3$ & Pt-S & 2.471 & 0.208 & 0.836 & 1.144 & 0.535 & $* *$ & $* *$ & 1.35 & 1.63 \\
\hline \multirow{3}{*}{195} & & $1-2$ & $\mathrm{Pt}-\mathrm{Cl}$ & 2.506 & 0.181 & 0.734 & 1.085 & 0.431 & $* *$ & $* *$ & 1.08 & 1.53 \\
\hline & $\diamond \quad$ HOM....... & $1-3$ & $\mathrm{Pt}-\mathrm{Cl}$ & 2.531 & 0.177 & 0.756 & 1.083 & 0.480 & $* *$ & $* *$ & 1.04 & 1.69 \\
\hline & & $1-5$ & $\mathrm{Pt}-\mathrm{O}$ & 2.020 & 0.350 & 0.796 & 1.162 & 0.383 & $* *$ & $* *$ & 2.82 & 3.02 \\
\hline \multirow{2}{*}{196} & {$\left[\text { cis- } \mathrm{Pt}(\mathrm{OH}){ }_{2} \mathrm{Cl}_{2}\right]^{2-}$} & $1-2$ & $\mathrm{Pt}-\mathrm{Cl}$ & 2.580 & 0.157 & 0.667 & 1.001 & 0.421 & $* *$ & $* *$ & 0.77 & 1.53 \\
\hline & & $1-5$ & Pt-O & 2.038 & 0.330 & 0.738 & 1.097 & 0.365 & $* *$ & $* *$ & 2.56 & 2.96 \\
\hline \multirow{2}{*}{197} & $\quad\left[\text { trans- } \mathrm{Pt}(\mathrm{OH})_{2} \mathrm{Cl}_{2}\right]^{2-}$ & $1-3$ & Pt-O & 2.067 & 0.310 & 0.742 & 1.070 & 0.413 & $* *$ & $* *$ & 2.40 & 2.88 \\
\hline & & $1-4$ & $\mathrm{Pt}-\mathrm{Cl}$ & 2.509 & 0.178 & 0.728 & 1.089 & 0.431 & $* *$ & $* *$ & 1.01 & 1.51 \\
\hline \multirow{3}{*}{198} & {$\left[\mathrm{H}_{2}^{3} \mathrm{~N} / \mu\right.$} & $1-2$ & Pt-N & 2.089 & 0.298 & 0.449 & 0.804 & 0.153 & $* *$ & $* *$ & 2.20 & 3.41 \\
\hline & 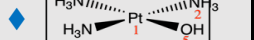 & $1-3$ & Pt-N & 2.150 & 0.256 & 0.355 & 0.738 & 0.122 & $* *$ & $* *$ & 1.64 & 3.31 \\
\hline & & $1-5$ & Pt-O & 1.989 & 0.365 & 0.829 & 1.140 & 0.431 & $* *$ & $* *$ & 3.40 & 4.25 \\
\hline \multirow{2}{*}{199} & $\left.\quad\left[\text { cis- } \mathrm{Pt}(\mathrm{HO})_{2} \mathrm{NH}_{3}\right)_{2}\right]$ & $1-2$ & $\mathrm{Pt}-\mathrm{O}$ & 2.016 & 0.339 & 0.719 & 1.082 & 0.374 & $* *$ & $* *$ & 3.01 & 4.00 \\
\hline & & $1-4$ & Pt-N & 2.118 & 0.280 & 0.384 & 0.753 & 0.117 & $* *$ & $* *$ & 2.02 & 3.36 \\
\hline \multirow{2}{*}{200} & [trans- $\left.\left.\mathrm{Pt}(\mathrm{HO})_{2} \mathrm{NH}_{3}\right)_{2}\right]$ & $1-2$ & Pt-O & 2.043 & 0.317 & 0.694 & 1.042 & 0.372 & $* *$ & $* *$ & 2.73 & 3.95 \\
\hline & & $1-3$ & Pt-N & 2.084 & 0.301 & 0.423 & 0.789 & 0.128 & $* *$ & $* *$ & 2.29 & 3.40 \\
\hline \multirow{3}{*}{201} & {$\left[\begin{array}{ll}4 & 2+\end{array}\right]^{2+}$} & $1-2$ & Pt-O & 2.119 & 0.229 & 0.292 & 0.657 & 0.117 & $* *$ & $* *$ & 1.80 & 4.12 \\
\hline & 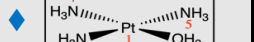 & $1-4$ & Pt-N & 2.066 & 0.330 & 0.566 & 0.901 & 0.243 & $* *$ & $* *$ & 2.15 & 3.80 \\
\hline & & $1-5$ & Pt-N & 2.097 & 0.296 & 0.497 & 0.832 & 0.217 & $* *$ & $* *$ & 2.15 & 3.51 \\
\hline
\end{tabular}




\begin{tabular}{|c|c|c|c|c|c|c|c|c|c|c|c|c|}
\hline 202 & $\checkmark \quad\left[\text { cis- } \mathrm{Pt}\left(\mathrm{NH}_{3}\right)_{2}\left(\mathrm{H}_{2} \mathrm{O}\right)_{2}\right]^{2+}$ & $\begin{array}{l}1-2 \\
1-4\end{array}$ & $\begin{array}{l}\text { Pt-N } \\
\text { Pt-O }\end{array}$ & $\begin{array}{l}2.053 \\
2.113\end{array}$ & $\begin{array}{l}0.341 \\
0.232\end{array}$ & $\begin{array}{l}0.596 \\
0.299\end{array}$ & $\begin{array}{l}0.924 \\
0.671\end{array}$ & $\begin{array}{l}0.259 \\
0.116\end{array}$ & $\begin{array}{l}* * \\
* *\end{array}$ & $\begin{array}{l}* * \\
* *\end{array}$ & $\begin{array}{l}2.64 \\
1.95\end{array}$ & $\begin{array}{l}3.83 \\
4.07\end{array}$ \\
\hline 203 & [trans-Pt $\left(\mathrm{NH}_{3}\right)_{2}\left(\mathrm{H}_{2} \mathrm{O}_{2}\right]^{2+}$ & $\begin{array}{l}1-2 \\
1-3\end{array}$ & $\begin{array}{l}\text { Pt-N } \\
\text { Pt-O }\end{array}$ & $\begin{array}{l}2.089 \\
2.077\end{array}$ & $\begin{array}{l}0.301 \\
0.263\end{array}$ & $\begin{array}{l}0.516 \\
0.335\end{array}$ & $\begin{array}{l}0.849 \\
0.730\end{array}$ & $\begin{array}{l}0.225 \\
0.122\end{array}$ & $\begin{array}{l}* * \\
* *\end{array}$ & $\begin{array}{l}* * \\
* *\end{array}$ & $\begin{array}{l}2.24 \\
2.02\end{array}$ & $\begin{array}{l}3.50 \\
4.30\end{array}$ \\
\hline 204 & $\mathrm{O}_{2}{ }^{2+}$ & $1-2$ & $0-0$ & 1.052 & 3.946 & 2.734 & 3.364 & 0.847 & $*$ & 3.041 & 31.79 & 31.79 \\
\hline 205 & 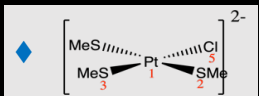 & $\begin{array}{l}1-2 \\
1-3 \\
1-5\end{array}$ & $\begin{array}{l}\text { Pt-S } \\
\text { Pt-S } \\
\text { Pt-Cl }\end{array}$ & $\begin{array}{l}2.484 \\
2.430 \\
2.530\end{array}$ & $\begin{array}{l}0.202 \\
0.230 \\
0.175\end{array}$ & $\begin{array}{l}0.796 \\
0.896 \\
0.698\end{array}$ & $\begin{array}{l}1.098 \\
1.185 \\
1.022\end{array}$ & $\begin{array}{l}0.508 \\
0.574 \\
0.431\end{array}$ & $\begin{array}{l}* * \\
* * \\
* *\end{array}$ & $\begin{array}{l}* * \\
* * \\
* *\end{array}$ & $\begin{array}{l}1.27 \\
1.55 \\
0.99\end{array}$ & $\begin{array}{l}1.55 \\
1.85 \\
1.38\end{array}$ \\
\hline 206 & 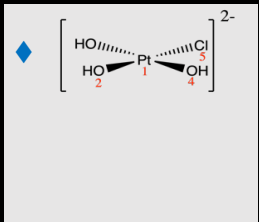 & $\begin{array}{l}1-2 \\
1-4 \\
1-5\end{array}$ & $\begin{array}{l}\text { Pt-O } \\
\text { Pt-O } \\
\\
\\
\mathrm{Pt}-\mathrm{Cl}\end{array}$ & $\begin{array}{l}2.038 \\
2.084\end{array}$ & $\begin{array}{l}0.313 \\
0.294\end{array}$ & $\begin{array}{l}0.735 \\
0.692\end{array}$ & $\begin{array}{l}1.067 \\
1.019\end{array}$ & $\begin{array}{l}0.416 \\
0.373\end{array}$ & $\begin{array}{l}* * \\
* *\end{array}$ & ** & $\begin{array}{l}2.50 \\
2.20\end{array}$ & $\begin{array}{l}2.78 \\
2.81\end{array}$ \\
\hline 207 & {$\left[\begin{array}{c}\mathrm{HO} \| \ldots \ldots \ldots \\
\mathrm{HO}_{3}\end{array}\right.$} & $\begin{array}{l}1-2 \\
1-3 \\
1-5\end{array}$ & $\begin{array}{l}\text { Pt-O } \\
\text { Pt-O } \\
\text { Pt-N }\end{array}$ & $\begin{array}{l}2.066 \\
2.023 \\
2.123\end{array}$ & $\begin{array}{l}0.302 \\
0.340 \\
0.271\end{array}$ & $\begin{array}{l}0.664 \\
0.779 \\
0.305\end{array}$ & $\begin{array}{l}1.006 \\
1.134 \\
0.710\end{array}$ & $\begin{array}{l}0.371 \\
0.414 \\
0.034\end{array}$ & $\begin{array}{l}* * \\
* * \\
* *\end{array}$ & $\begin{array}{l}* * \\
* * \\
* *\end{array}$ & $\begin{array}{l}2.38 \\
2.79 \\
1.87\end{array}$ & $\begin{array}{l}3.27 \\
3.49 \\
2.86\end{array}$ \\
\hline 208 & 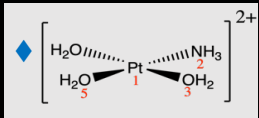 & $\begin{array}{l}1-2 \\
1-3 \\
1-5\end{array}$ & $\begin{array}{l}\text { Pt-N } \\
\text { Pt-O } \\
\text { Pt-O }\end{array}$ & $\begin{array}{l}2.044 \\
2.068 \\
2.104\end{array}$ & $\begin{array}{l}0.349 \\
0.270 \\
0.237\end{array}$ & $\begin{array}{l}0.624 \\
0.349 \\
0.303\end{array}$ & $\begin{array}{l}0.948 \\
0.748 \\
0.692\end{array}$ & $\begin{array}{l}0.270 \\
0.127 \\
0.111\end{array}$ & $\begin{array}{l}* * \\
* * \\
* *\end{array}$ & $\begin{array}{l}* * \\
* * \\
* *\end{array}$ & $\begin{array}{l}2.67 \\
2.09 \\
\\
1.92\end{array}$ & $\begin{array}{l}3.83 \\
4.22 \\
4.10\end{array}$ \\
\hline 209 & {$\left[\mathrm{Ni}(\mathrm{CN})_{4}\right]^{2-}$} & $\begin{array}{l}1-2 \\
2-8\end{array}$ & $\begin{array}{l}\mathrm{Ni}-\mathrm{C} \\
\mathrm{C}-\mathrm{N}\end{array}$ & $\begin{array}{l}1.953 \\
1.166\end{array}$ & $\begin{array}{l}0.333 \\
2.298\end{array}$ & $\begin{array}{l}0.735 \\
2.680\end{array}$ & $\begin{array}{l}0.886 \\
3.173\end{array}$ & $\begin{array}{l}0.345 \\
1.573\end{array}$ & $\begin{array}{l}* \\
*\end{array}$ & $\begin{array}{l}0.614 \\
2.195\end{array}$ & $\begin{array}{c}1.26 \\
19.38\end{array}$ & $\begin{array}{c}7.03 \\
20.22\end{array}$ \\
\hline 210 & {$\left[\mathrm{Ni}\left(\mathrm{H}_{2} \mathrm{O}\right)_{6}\right]^{2+}$} & $\begin{array}{c}2-4 \\
4-15\end{array}$ & $\begin{array}{l}\mathrm{Ni}-\mathrm{O} \\
\mathrm{O}-\mathrm{H}\end{array}$ & $\begin{array}{l}1.915 \\
0.968\end{array}$ & $\begin{array}{l}0.279 \\
1.338\end{array}$ & $\begin{array}{l}0.362 \\
0.811\end{array}$ & $\begin{array}{l}0.582 \\
0.953\end{array}$ & $\begin{array}{l}0.229 \\
0.611\end{array}$ & $\begin{array}{l}* \\
*\end{array}$ & $\begin{array}{l}0.393 \\
0.533\end{array}$ & $\begin{array}{l}1.90 \\
8.35\end{array}$ & $\begin{array}{l}3.97 \\
8.93\end{array}$ \\
\hline 211 & {$\left[\mathrm{NiCl}_{4}\right]^{2-}$} & $1-2$ & $\mathrm{Ni}-\mathrm{Cl}$ & 2.299 & 0.205 & 0.625 & 0.868 & 0.339 & $*$ & 0.506 & 3.48 & 3.33 \\
\hline 212 & 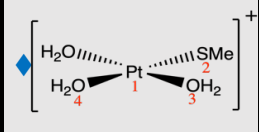 & $\begin{array}{l}1-2 \\
1-3 \\
1-4\end{array}$ & $\begin{array}{l}\text { Pt-S } \\
\text { Pt-O } \\
\text { Pt-O }\end{array}$ & $\begin{array}{l}2.345 \\
2.067 \\
2.220\end{array}$ & $\begin{array}{l}0.260 \\
0.267 \\
0.161\end{array}$ & $\begin{array}{l}1.154 \\
0.297 \\
0.181\end{array}$ & $\begin{array}{l}1.422 \\
0.719 \\
0.556\end{array}$ & $\begin{array}{r}0.544 \\
0.070 \\
-0.007\end{array}$ & $\begin{array}{l}* * \\
* * \\
* *\end{array}$ & $\begin{array}{l}* * \\
* * \\
* *\end{array}$ & $\begin{array}{l}2.37 \\
2.09 \\
1.16\end{array}$ & $\begin{array}{l}2.98 \\
4.03 \\
3.53\end{array}$ \\
\hline 213 & 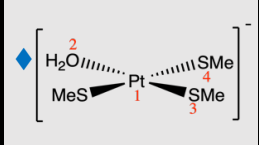 & $\begin{array}{l}1-2 \\
1-4 \\
1-3\end{array}$ & $\begin{array}{l}\text { Pt-O } \\
\text { Pt-S } \\
\text { Pt-S }\end{array}$ & $\begin{array}{l}2.197 \\
2.456 \\
\\
2.360\end{array}$ & $\begin{array}{l}0.209 \\
0.264\end{array}$ & $\begin{array}{l}1.044 \\
0.830\end{array}$ & $\begin{array}{l}1.291 \\
1.097\end{array}$ & $\begin{array}{l}0.054 \\
0.625 \\
0.533\end{array}$ & $* *$ & $\begin{array}{l}* * \\
* *\end{array}$ & $\begin{array}{l}1.37 \\
2.06\end{array}$ & $\begin{array}{l}2.11 \\
2.43 \\
\\
1.79\end{array}$ \\
\hline 214 & {$\left[\mathrm{Pt}(\mathrm{CN})_{4}\right]^{2-}$} & $\begin{array}{l}1-2 \\
2-9\end{array}$ & $\begin{array}{l}\text { Pt-C } \\
\text { C-N }\end{array}$ & $\begin{array}{l}2.024 \\
1.194\end{array}$ & $\begin{array}{l}0.438 \\
2.147\end{array}$ & $\begin{array}{l}0.728 \\
2.619\end{array}$ & $\begin{array}{l}1.092 \\
2.920\end{array}$ & $\begin{array}{l}0.146 \\
1.190\end{array}$ & $\begin{array}{l}* * \\
* *\end{array}$ & $\begin{array}{l}* * \\
* *\end{array}$ & $\begin{array}{c}2.11 \\
16.85\end{array}$ & $\begin{array}{c}6.72 \\
15.80\end{array}$ \\
\hline 215 & {$\left[\mathrm{Fe}(\mathrm{CO})_{4}\right]^{2-}$} & $\begin{array}{l}1-2 \\
2-8\end{array}$ & $\begin{array}{l}\mathrm{Fe}-\mathrm{C} \\
\mathrm{C}-\mathrm{O}\end{array}$ & $\begin{array}{l}1.745 \\
1.194\end{array}$ & $\begin{array}{l}0.609 \\
2.100\end{array}$ & $\begin{array}{l}1.465 \\
1.692\end{array}$ & $\begin{array}{l}1.737 \\
2.256\end{array}$ & $\begin{array}{l}0.764 \\
0.867\end{array}$ & $\begin{array}{l}* \\
*\end{array}$ & $\begin{array}{l}1.352 \\
1.394\end{array}$ & $\begin{array}{c}3.76 \\
13.53\end{array}$ & $\begin{array}{c}6.00 \\
13.45\end{array}$ \\
\hline 216 & {$\left[\mathrm{Ni}\left(\mathrm{CH}_{3}\right)_{4}\right]^{2-}$} & $\begin{array}{l}1-2 \\
2-8\end{array}$ & $\begin{array}{l}\mathrm{Ni}-\mathrm{C} \\
\mathrm{C}-\mathrm{H}\end{array}$ & $\begin{array}{l}1.977 \\
1.115\end{array}$ & $\begin{array}{l}0.359 \\
0.886\end{array}$ & $\begin{array}{l}0.720 \\
0.933\end{array}$ & $\begin{array}{l}0.939 \\
0.952\end{array}$ & $\begin{array}{l}0.132 \\
0.599\end{array}$ & * & $\begin{array}{l}0.720 \\
0.985\end{array}$ & $\begin{array}{l}2.05 \\
4.66\end{array}$ & $\begin{array}{l}2.77 \\
5.10\end{array}$ \\
\hline
\end{tabular}




\begin{tabular}{|c|c|c|c|c|c|c|c|c|c|c|c|c|}
\hline \multirow{6}{*}{217} & & $10-7$ & O-C & 1.423 & 1.068 & 0.881 & 1.096 & 0.473 & 1.445 & 0.841 & & 5.52 \\
\hline & & 7-11 & $\mathrm{C}-\mathrm{H}$ & 1.100 & 0.858 & 0.946 & 0.930 & 0.783 & 1.000 & 0.910 & & 5.92 \\
\hline & & $7-4$ & $C-C$ & 1.523 & 0.826 & 0.982 & 1.063 & 0.693 & 1.000 & 0.955 & & 5.46 \\
\hline & & $4-8$ & C-H & 1.094 & 0.878 & 0.952 & 0.934 & 0.761 & 1.000 & 0.950 & & 6.26 \\
\hline & & $4-2$ & $c-c$ & 1.531 & 0.820 & 0.992 & 1.054 & 0.719 & 1.000 & 0.976 & & 5.48 \\
\hline & & $2-5$ & $\mathrm{C}-\mathrm{H}$ & 1.098 & 0.865 & 0.948 & 0.931 & 0.777 & 1.000 & 0.939 & & 5.87 \\
\hline \multirow{8}{*}{218} & & $16-17$ & $\mathrm{O}-\mathrm{H}$ & 0.965 & 1.409 & 0.865 & 0.979 & 0.595 & 0.930 & 0.626 & & 8.76 \\
\hline & & $13-16$ & C-O & 1.365 & 1.267 & 0.943 & 1.247 & 0.544 & 0.685 & 0.902 & & 7.32 \\
\hline & & $1-13$ & $C-C$ & 1.336 & 1.390 & 1.847 & 1.851 & 1.364 & 1.000 & 1.679 & & 11.24 \\
\hline & & $1-3$ & $\mathrm{C}-\mathrm{H}$ & 1.089 & 0.908 & 0.940 & 0.920 & 0.741 & 1.000 & 0.960 & & 6.70 \\
\hline & & $2-1$ & $C-C$ & 1.507 & 0.866 & 0.992 & 1.067 & 0.679 & 1.000 & 1.011 & & 6.26 \\
\hline & & $2-6$ & $\mathrm{C}-\mathrm{H}$ & 1.096 & 0.873 & 0.952 & 0.931 & 0.784 & 1.000 & 0.942 & & 6.01 \\
\hline & & $4-2$ & $C-C$ & 1.530 & 0.824 & 0.999 & 1.058 & 0.737 & 1.000 & 0.976 & & 5.41 \\
\hline & & 4-8 & $\mathrm{C}-\mathrm{H}$ & 1.094 & 0.878 & 0.957 & 0.938 & 0.780 & 1.000 & 0.949 & & 6.17 \\
\hline & & 23-14 & $\mathrm{H}-\mathrm{O}$ & 1.937 & 0.076 & 0.102 & 0.091 & 0.105 & $*$ & 0.075 & & 2.90 \\
\hline & & $1-26$ & $\mathrm{~N}-\mathrm{H}$ & 1.736 & 0.137 & 0.172 & 0.188 & 1.178 & $*$ & 0.142 & & 2.73 \\
\hline 220 & & $5-8$ & $\mathrm{H}-\mathrm{O}$ & 1.605 & 0.161 & 0.153 & 0.201 & 0.136 & $*$ & 0.124 & & 2.43 \\
\hline 221 & & $2-7$ & $\mathrm{H}-\mathrm{O}$ & 1.653 & 0.141 & 0.144 & 0.189 & 0.136 & $*$ & 0.116 & 0.44 & 1.72 \\
\hline 222 & $\mathrm{CH}_{3} \mathrm{NH}_{2}-\mathrm{HCl}$ & $3-2$ & $\mathrm{~N}-\mathrm{H}$ & 1.457 & 0.271 & 0.220 & 0.354 & 0.019 & * & 0.285 & 0.72 & 1.21 \\
\hline 223 & $\mathrm{CH}_{3} \mathrm{OH}-\mathrm{HF}$ & $3-2$ & $\mathrm{O}-\mathrm{H}$ & 1.695 & 0.113 & 0.109 & 0.158 & 0.103 & * & 0.087 & 0.42 & 2.28 \\
\hline 224 & $\mathrm{CH}_{3} \mathrm{NH}_{2}-\mathrm{HF}$ & $3-2$ & $\mathrm{~N}-\mathrm{H}$ & 1.670 & 0.132 & 0.131 & 0.231 & 0.105 & * & 0.125 & 0.53 & 2.55 \\
\hline 225 & $\mathrm{CH}_{3} \mathrm{I}--\mathrm{OCH}_{2}$ & $2-6$ & $1-0$ & 3.134 & 0.021 & 0.022 & 0.035 & 0.000 & ** & ** & 0.12 & 1.15 \\
\hline 226 & $\mathrm{CH}_{3} \mathrm{OH}--\mathrm{FCH}_{3}$ & $7-1$ & $\mathrm{~F}-\mathrm{H}$ & 1.941 & 0.062 & 0.072 & 0.063 & 0.068 & * & 0.045 & 0.27 & 1.64 \\
\hline 227 & & $12-13$ & $\mathrm{Br}-\mathrm{O}$ & 3.080 & 0.020 & 0.020 & 0.026 & 0.001 & $* *$ & ** & 0.10 & 2.04 \\
\hline 228 & $\mathrm{CH}_{3} \mathrm{Br}--\mathrm{OCH}_{2}$ & $2-6$ & $\mathrm{Br}-\mathrm{O}$ & 3.155 & 0.016 & 0.010 & 0.017 & -0.004 & * & 0.085 & 0.10 & 1.15 \\
\hline
\end{tabular}




\begin{tabular}{|c|c|c|c|c|c|c|c|c|c|c|c|c|}
\hline 229 & $\mathrm{NH}$ & $1-2$ & $\mathrm{~N}-\mathrm{H}$ & 1.042 & 1.085 & 0.880 & 1.020 & 0.457 & 1.205 & 0.930 & 5.99 & 5.99 \\
\hline 230 & $\mathrm{CO}$ & $1-2$ & $\mathrm{C}-\mathrm{O}$ & 1.132 & 2.364 & 2.378 & 2.962 & 1.162 & 1.090 & 1.696 & 21.06 & 21.06 \\
\hline 231 & $\mathrm{NO}$ & $1-2$ & $\mathrm{~N}-\mathrm{O}$ & 1.148 & 2.706 & 1.946 & 2.615 & 0.570 & 1.170 & 2.368 & 19.39 & 19.39 \\
\hline 232 & $\mathrm{~S}_{2}$ & $1-2$ & S-S & 1.902 & 0.729 & 1.860 & 2.279 & 0.338 & 1.240 & 2.287 & 5.34 & 5.34 \\
\hline 233 & $\mathrm{~S}_{2}{ }^{2-}$ & $1-2$ & S-S & 2.220 & 0.346 & 0.908 & 1.187 & -0.067 & 0.735 & 1.397 & 1.58 & 1.58 \\
\hline 234 & $\mathrm{CN}$ & $1-2$ & $C-N$ & 1.179 & 2.128 & 2.817 & 3.332 & 1.530 & 1.785 & 2.210 & 18.39 & 18.39 \\
\hline 235 & $\mathrm{H}_{2} \mathrm{O}--\mathrm{H}_{2} \mathrm{O}$ & $1-2$ & $\mathrm{O}-\mathrm{H}$ & 1.932 & 0.084 & 0.123 & 0.116 & 0.113 & & 0.086 & 0.23 & 1.98 \\
\hline
\end{tabular}




\section{Effect of polarization and diffuse functions on IBSI}

A limited study has been carried out to address the influence of the inclusion of diffuse function to the $6-31 \mathrm{G}^{* *}$ basis set. Also, the effect of adding polarization functions to the LANL2DZ basis set has been examined. A total of 9 molecules has been considered, covering different kinds of chemical bonds. The results are reported in the table below.
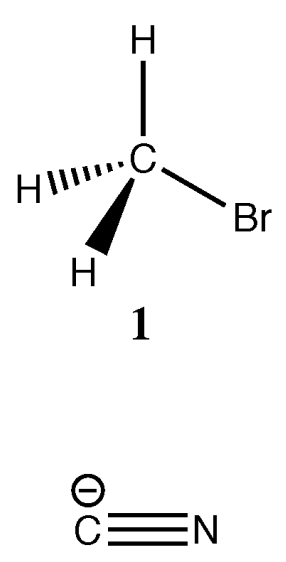

4

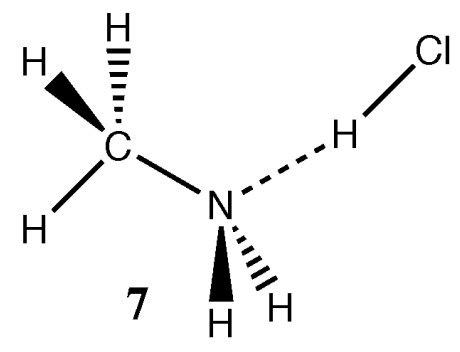

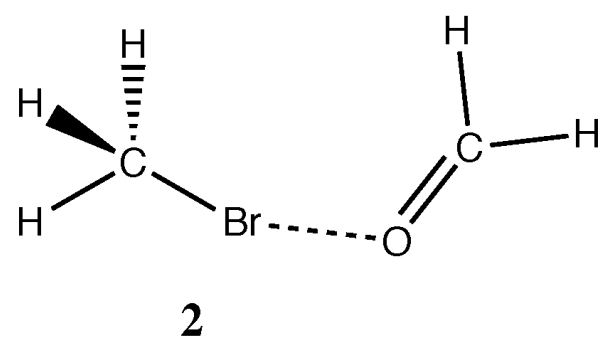
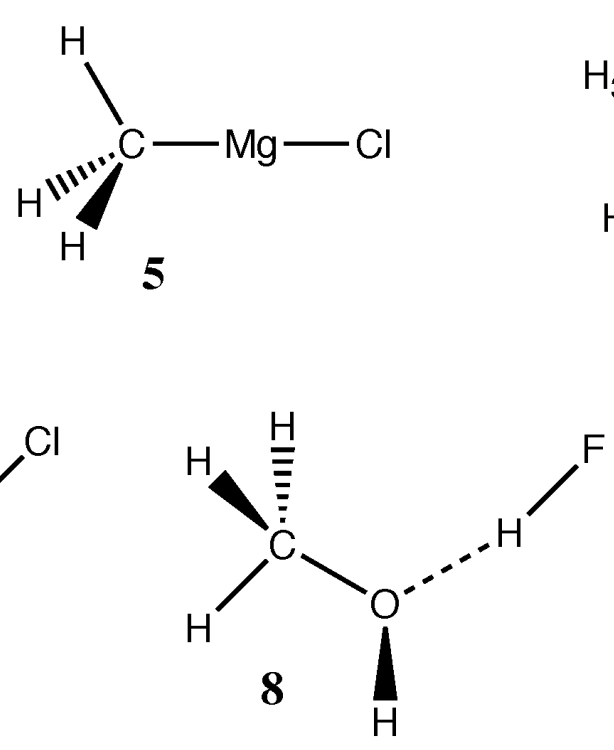

Figure S5
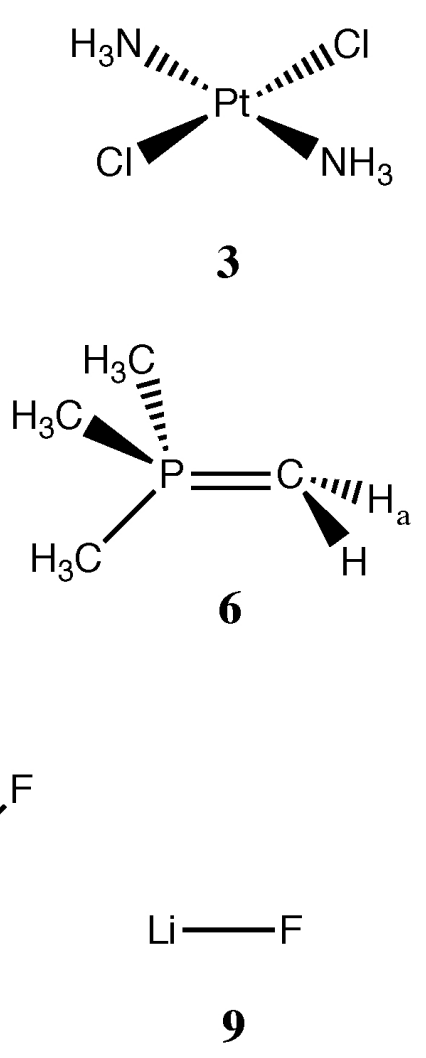


\begin{tabular}{|c|c|c|c|c|c|c|c|}
\hline $\mathbf{N}^{\circ}$ & Bond & $R(\AA)$ & $\begin{array}{r}\text { local } k_{1} \\
\text { (mdyn/Å }\end{array}$ & IBSI & $\mathbf{R}(\AA)$ & $\begin{array}{r}\text { local k } \\
\text { (mdyn/Å }\end{array}$ & IBSI \\
\hline & & \multicolumn{3}{|c|}{ M06-2X/LANL2DZ } & \multicolumn{3}{|c|}{ M06-2X/LANL2DZdp ${ }^{a}$} \\
\hline 1.1 & $\mathrm{C}-\mathrm{H}$ & 1.087 & 5.66 & 0.870 & 1.091 & 5.54 & 0.855 \\
\hline 1.2 & $\mathrm{C}-\mathrm{Br}$ & 2.004 & 2.76 & 0.428 & 1.951 & 3.03 & 0.487 \\
\hline 2.1 & $\mathrm{Br} . . . \mathrm{O}$ & 3.155 & 0.10 & 0,016 & 3.123 & 0.11 & 0.017 \\
\hline 3.1 & Pt-N & 2.070 & 2.43 & 0.312 & 2.047 & 2.20 & 0.360 \\
\hline \multirow[t]{2}{*}{3.2} & $\mathrm{Pt}-\mathrm{Cl}$ & 2.416 & 1.84 & 0.216 & 2.332 & 1.67 & 0.278 \\
\hline & & \multicolumn{3}{|c|}{$\mathrm{M} 06-2 \mathrm{X} / 6-31 \mathrm{G} * *$} & \multicolumn{3}{|c|}{$\mathrm{M} 06-2 \mathrm{X} / 6-31+\mathrm{G} * *$} \\
\hline 4.1 & $\mathrm{C} \equiv \mathrm{N}$ & 1.179 & 18.39 & 2.128 & 1.178 & 18.16 & 2.145 \\
\hline 5.1 & $\mathrm{Mg}-\mathrm{C}$ & 2.068 & 1.80 & 0.158 & 2.071 & 1.79 & 0.142 \\
\hline 5.2 & $\mathrm{C}-\mathrm{H}$ & 1.093 & 5.31 & 0.898 & 1.094 & 5.40 & 0.892 \\
\hline 5.3 & $\mathrm{Mg}-\mathrm{Cl}$ & 2.203 & 1.97 & 0.173 & 2.205 & 1.95 & 0.184 \\
\hline 6.1 & $\mathrm{P}=\mathrm{C}$ & 1.673 & 5.66 & 0.828 & 1.678 & 5.63 & 0.808 \\
\hline 6.2 & $\mathrm{C}-\mathrm{Ha}$ & 1.084 & 5.76 & 0.940 & 1.085 & 5.75 & 0.929 \\
\hline 6.3 & $\mathrm{P}-\mathrm{C}$ & 1.824 & 3.47 & 0.534 & 1.823 & 3.39 & 0.540 \\
\hline 7.1 & N...H & 1.457 & 0.72 & 0.271 & 1.364 & 0.96 & 0.343 \\
\hline 8.1 & $\mathrm{O} \ldots \mathrm{H}$ & 1.695 & 0.42 & 0.113 & 1.629 & 0.36 & 0.111 \\
\hline 9.1 & $\mathrm{Li}-\mathrm{F}$ & 1.550 & 3.21 & 0.182 & 1.578 & 2.58 & 0.154 \\
\hline
\end{tabular}

a LANL2TZ(f) for the metal 


\section{KC-AIM stretching force constant versus IBSI}

Based on the local Konkoli-Cremer AIM mode force constants $k^{a}$ taken from reference ${ }^{3}$ for 39 molecules and a set (SET4) of 145 bonds, an additional comparison is reported below between IBSI and $k^{a}$. For the sake of comparison with data taken from literature, the geometry was obtained at the DFT(B3LYP/6-31G(d,p)) level of theory. The set SET3 of bonds not belonging to a ring is also considered. Linear (full line) and quadratic correlation (dashed line) between the IBSI and force constant $k^{a}$ are reported. The list of molecules addressed for this comparison is reported below as well. It is to be noticed that molecule 9 studied in the original paper by Cremer et al. has not been reported here because the geometry we obtained for HCN didn't correspond to the geometry reported in that previous paper.
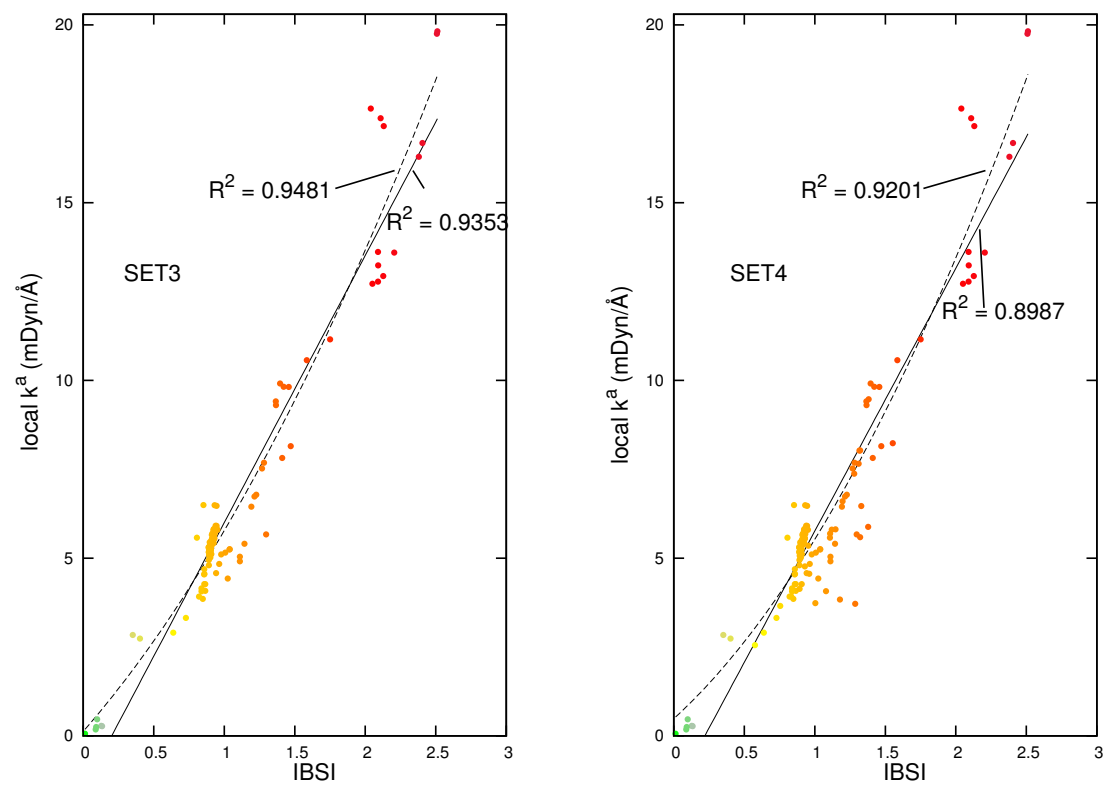

Figure S6 

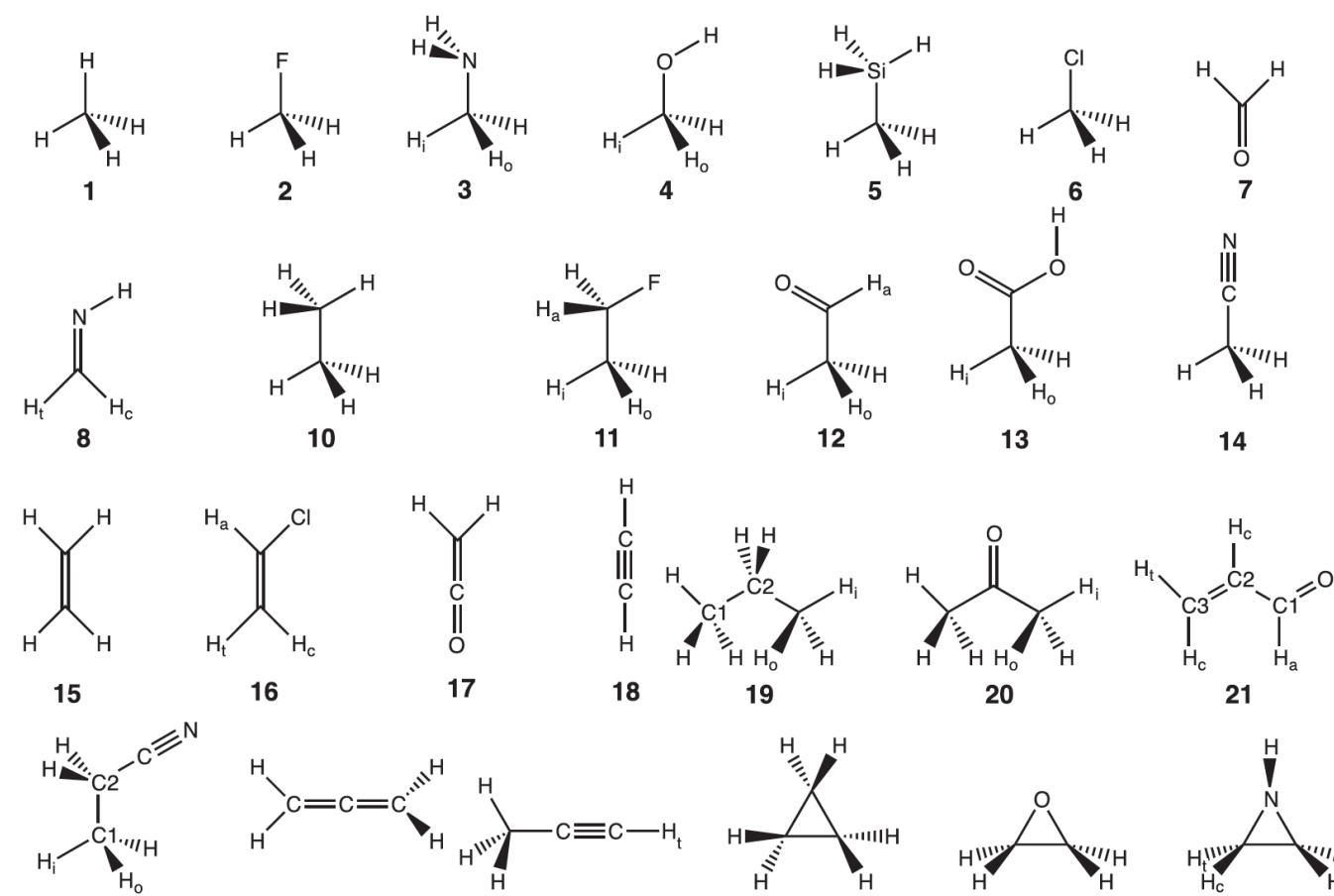

16

17
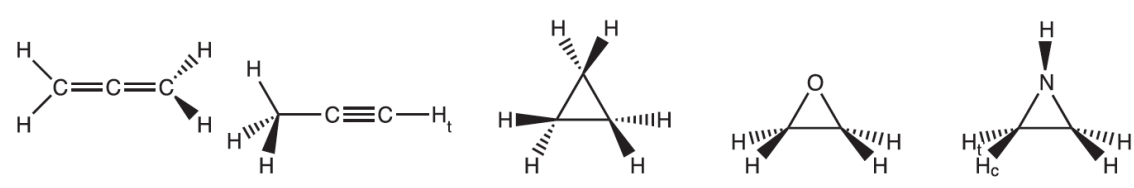

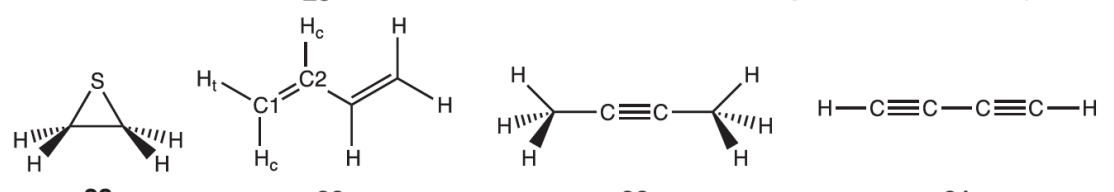

31

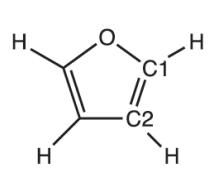<smiles>Cn1cccc1</smiles>

33

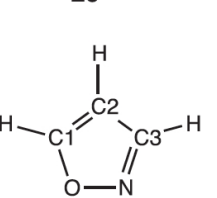

34<smiles>O=C1C=CC=[O+]1</smiles>

35<smiles></smiles>

36<smiles>C1CCCCC1</smiles>

37<smiles>c1ccccc1</smiles>

38

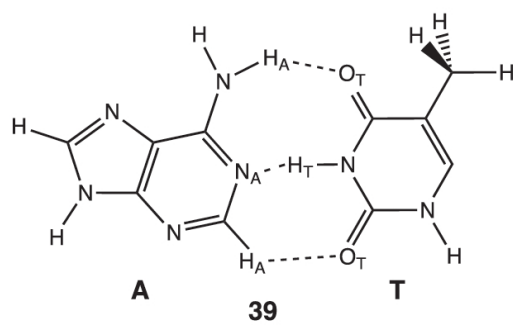

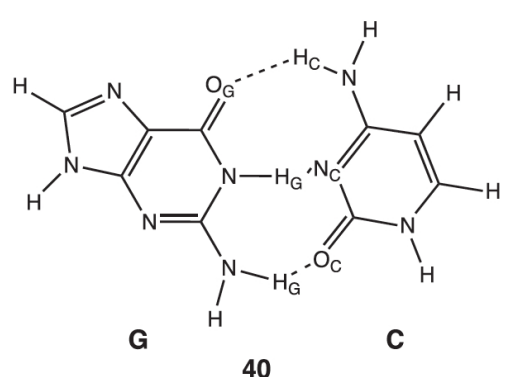

Figure S7 


\begin{tabular}{|c|c|c|c|c|c|}
\hline $\mathbf{N}^{0}$ & Bond & $R(\AA ̊)$ & $\begin{array}{c}\text { local k } \\
\text { (mDyne/Å) }\end{array}$ & IBSI & intracyclic \\
\hline 1.1 & $\mathrm{C}-\mathrm{H}$ & 1.092 & 5.365 & 0.905 & \\
\hline 2.1 & $\mathrm{C}-\mathrm{H}$ & 1.096 & 5.178 & 0.893 & \\
\hline 2.2 & $\mathrm{C}-\mathrm{F}$ & 1.383 & 5.405 & 1.144 & \\
\hline 3.1 & $\mathrm{C}-\mathrm{Hi}$ & 1.104 & 4.798 & 0.891 & \\
\hline 3.2 & $\mathrm{C}-\mathrm{Ho}$ & 1.095 & 5.211 & 0.895 & \\
\hline 3.3 & $\mathrm{C}-\mathrm{N}$ & 1.464 & 4.426 & 1.025 & \\
\hline 3.4 & $\mathrm{~N}-\mathrm{H}$ & 1.017 & 6.783 & 1.227 & \\
\hline 4.1 & $\mathrm{C}-\mathrm{O}$ & 1.418 & 4.908 & 1.111 & \\
\hline 4.2 & $\mathrm{C}-\mathrm{Hi}$ & 1.093 & 5.298 & 0.892 & \\
\hline 4.3 & $\mathrm{C}-\mathrm{Ho}$ & 1.101 & 4.946 & 0.891 & \\
\hline 4.4 & $\mathrm{O}-\mathrm{H}$ & 0.965 & 8.15 & 1.471 & \\
\hline 5.1 & $\mathrm{C}-\mathrm{H}$ & 1.094 & 5.258 & 0.905 & \\
\hline 5.2 & $\mathrm{C}-\mathrm{Si}$ & 1.888 & 2.738 & 0.402 & \\
\hline 5.3 & $\mathrm{Si}-\mathrm{H}$ & 1.488 & 2.838 & 0.351 & \\
\hline 6.1 & $\mathrm{C}-\mathrm{H}$ & 1.089 & 5.445 & 0.897 & \\
\hline 6.2 & $\mathrm{C}-\mathrm{Cl}$ & 1.803 & 2.903 & 0.639 & \\
\hline 7.1 & $\mathrm{C}-\mathrm{H}$ & 1.110 & 4.687 & 0.859 & \\
\hline 7.2 & $C=0$ & 1.207 & 13.612 & 2.090 & \\
\hline 8.1 & $\mathrm{C}-\mathrm{Hc}$ & 1.099 & 5.062 & 0.893 & \\
\hline 8.2 & $\mathrm{C}-\mathrm{Ht}$ & 1.094 & 5.314 & 0.891 & \\
\hline 8.3 & $\mathrm{C}=\mathrm{N}$ & 1.270 & 11.155 & 1.751 & \\
\hline 8.4 & $\mathrm{~N}-\mathrm{H}$ & 1.026 & 6.448 & 1.192 & \\
\hline 10.1 & $\mathrm{C}-\mathrm{H}$ & 1.095 & 5.215 & 0.903 & \\
\hline 10.2 & $C-C$ & 1.530 & 4.149 & 0.839 & \\
\hline 11.1 & $\mathrm{C}-\mathrm{Hi}$ & 1.095 & 5.237 & 0.905 & \\
\hline 11.2 & $\mathrm{C}-\mathrm{Ho}$ & 1.094 & 5.284 & 0.902 & \\
\hline 11.3 & $\mathrm{C}-\mathrm{Ha}$ & 1.097 & 5.096 & 0.895 & \\
\hline 11.4 & $\mathrm{C}-\mathrm{C}$ & 1.516 & 4.269 & 0.858 & \\
\hline 11.5 & $\mathrm{C}-\mathrm{F}$ & 1.393 & 5.040 & 1.111 & \\
\hline 12.1 & $\mathrm{C}-\mathrm{Ho}$ & 1.097 & 5.148 & 0.895 & \\
\hline 12.2 & $\mathrm{C}-\mathrm{Hi}$ & 1.091 & 5.407 & 0.901 & \\
\hline 12.3 & $\mathrm{C}-\mathrm{Ha}$ & 1.114 & 4.540 & 0.857 & \\
\hline 12.4 & $\mathrm{C}-\mathrm{C}$ & 1.507 & 4.081 & 0.865 & \\
\hline 12.5 & $C=0$ & 1.211 & 13.234 & 2.091 & \\
\hline 13.1 & $\mathrm{C}-\mathrm{Ho}$ & 1.094 & 5.224 & 0.896 & \\
\hline 13.2 & $\mathrm{C}-\mathrm{Hi}$ & 1.089 & 5.485 & 0.907 & \\
\hline 13.3 & $C-C$ & 1.507 & 4.268 & 0.866 & \\
\hline 13.4 & $\mathrm{C}-\mathrm{O}$ & 1.358 & 5.666 & 1.297 & \\
\hline 13.5 & $C=O$ & 1.210 & 12.933 & 2.127 & \\
\hline 13.6 & $\mathrm{O}-\mathrm{H}$ & 0.972 & 7.817 & 1.411 & \\
\hline 14.1 & $\mathrm{C}-\mathrm{H}$ & 1.093 & 5.299 & 0.889 & \\
\hline 14.2 & $C-C$ & 1.460 & 5.105 & 0.978 & \\
\hline 14.3 & $\mathrm{C} \equiv \mathrm{N}$ & 1.160 & 19.820 & 2.512 & \\
\hline 15.1 & $\mathrm{C}-\mathrm{H}$ & 1.087 & 5.572 & 0.921 & \\
\hline 15.2 & $C=C$ & 1.330 & 9.911 & 1.396 & \\
\hline 16.1 & $\mathrm{C}-\mathrm{Ha}$ & 1.084 & 5.688 & 0.915 & \\
\hline
\end{tabular}




\begin{tabular}{|c|c|c|c|c|c|}
\hline 16.2 & $\mathrm{C}-\mathrm{Ht}$ & 1.085 & 5.642 & 0.920 & \\
\hline 16.3 & $\mathrm{C}-\mathrm{HC}$ & 1.084 & 5.688 & 0.920 & \\
\hline 16.4 & $C=C$ & 1.327 & 9.818 & 1.421 & \\
\hline 16.5 & $\mathrm{C}-\mathrm{Cl}$ & 1.752 & 3.320 & 0.728 & \\
\hline 17.1 & $\mathrm{C}-\mathrm{H}$ & 1.082 & 5.757 & 0.933 & \\
\hline 17.2 & $C=C$ & 1.314 & 9.815 & 1.457 & \\
\hline 17.3 & $C=0$ & 1.171 & 16.290 & 2.380 & \\
\hline 18.1 & $\mathrm{C}-\mathrm{H}$ & 1.066 & 6.472 & 0.946 & \\
\hline 18.2 & $C \equiv C$ & 1.205 & 17.645 & 2.039 & \\
\hline 19.1 & C1-Ho & 1.096 & 5.178 & 0.902 & \\
\hline 19.2 & $\mathrm{C} 1-\mathrm{Hi}$ & 1.095 & 5.217 & 0.904 & \\
\hline 19.3 & $\mathrm{C} 2-\mathrm{H}$ & 1.098 & 5.088 & 0.902 & \\
\hline 19.4 & C1-C2 & 1.532 & 4.066 & 0.839 & \\
\hline 20.1 & $\mathrm{C}-\mathrm{Ho}$ & 1.096 & 5.100 & 0.898 & \\
\hline 20.2 & $\mathrm{C}-\mathrm{Hi}$ & 1.091 & 5.421 & 0.902 & \\
\hline 20.3 & $C-C$ & 1.520 & 3.853 & 0.848 & \\
\hline 20.4 & $C=0$ & 1.216 & 12.777 & 2.090 & \\
\hline 21.1 & $\mathrm{C} 3-\mathrm{Hc}$ & 1.088 & 5.539 & 0.913 & \\
\hline 21.2 & $\mathrm{C} 3-\mathrm{Ht}$ & 1.085 & 5.651 & 0.912 & \\
\hline 21.3 & $\mathrm{C} 2-\mathrm{Hc}$ & 1.087 & 5.574 & 0.806 & \\
\hline 21.4 & $\mathrm{C} 1-\mathrm{Ha}$ & 1.114 & 4.555 & 0.860 & \\
\hline 21.5 & $C 2=C 3$ & 1.337 & 9.410 & 1.366 & \\
\hline 21.6 & $\mathrm{C} 1-\mathrm{C} 2$ & 1.475 & 4.577 & 0.942 & \\
\hline 21.7 & $\mathrm{C} 1=0$ & 1.215 & 12.719 & 2.051 & \\
\hline 22.1 & $\mathrm{C} 1-\mathrm{Hi}$ & 1.093 & 5.299 & 0.903 & \\
\hline 22.2 & C1-Ho & 1.093 & 5.319 & 0.900 & \\
\hline 22.3 & $\mathrm{C} 2-\mathrm{H}$ & 1.096 & 5.170 & 0.890 & \\
\hline 22.4 & C1-C2 & 1.539 & 3.916 & 0.821 & \\
\hline 22.5 & $\mathrm{C}-\mathrm{C} 2$ & 1.466 & 4.834 & 0.964 & \\
\hline 22.6 & $\mathrm{C} \equiv \mathrm{N}$ & 1.161 & 19.750 & 2.508 & \\
\hline 23.1 & $\mathrm{C}-\mathrm{H}$ & 1.087 & 5.521 & 0.914 & \\
\hline 23.2 & $C=C$ & 1.306 & 10.569 & 1.586 & \\
\hline 24.1 & $\mathrm{C}-\mathrm{H}$ & 1.095 & 5.195 & 0.893 & \\
\hline 24.2 & $\mathrm{C}-\mathrm{Ht}$ & 1.065 & 6.488 & 0.932 & \\
\hline 24.3 & $C-C$ & 1.459 & 5.250 & 1.039 & \\
\hline 24.4 & $C \equiv C$ & 1.207 & 17.373 & 2.109 & \\
\hline 25.1 & $\mathrm{C}-\mathrm{H}$ & 1.086 & 5.540 & 0.929 & \\
\hline 25.2 & $C-C$ & 1.508 & 4.137 & 0.892 & yes \\
\hline 26.1 & $\mathrm{C}-\mathrm{H}$ & 1.090 & 5.366 & 0.912 & \\
\hline 26.2 & $\mathrm{C}-\mathrm{C}$ & 1.469 & 5.349 & 0.954 & yes \\
\hline 26.3 & $\mathrm{C}-\mathrm{O}$ & 1.430 & 4.068 & 1.080 & yes \\
\hline 27.1 & $\mathrm{C}-\mathrm{Ht}$ & 1.087 & 5.477 & 0.918 & \\
\hline 27.2 & $\mathrm{C}-\mathrm{Hc}$ & 1.088 & 5.419 & 0.923 & \\
\hline 27.3 & $\mathrm{C}-\mathrm{C}$ & 1.485 & 4.769 & 0.929 & yes \\
\hline 27.4 & $C-N$ & 1.473 & 3.733 & 1.004 & yes \\
\hline 27.5 & $\mathrm{~N}-\mathrm{H}$ & 1.019 & 6.734 & 1.214 & \\
\hline 28.1 & $\mathrm{C}-\mathrm{H}$ & 1.086 & 5.538 & 0.913 & \\
\hline 28.2 & $C-C$ & 1.481 & 4.559 & 0.961 & yes \\
\hline
\end{tabular}




\begin{tabular}{|c|c|c|c|c|c|}
\hline 28.3 & C-S & 1.837 & 2.552 & 0.576 & yes \\
\hline 29.1 & $\mathrm{C} 1-\mathrm{Hc}$ & 1.087 & 5.554 & 0.926 & \\
\hline 29.2 & $\mathrm{C} 1-\mathrm{Ht}$ & 1.085 & 5.636 & 0.924 & \\
\hline 29.3 & $\mathrm{C} 2-\mathrm{Hc}$ & 1.090 & 5.429 & 0.925 & \\
\hline 29.4 & $\mathrm{C} 1=\mathrm{C} 2$ & 1.340 & 9.301 & 1.367 & \\
\hline 29.5 & $\mathrm{C} 2-\mathrm{C} 2$ & 1.457 & 5.153 & 1.007 & \\
\hline 30.1 & $\mathrm{C}-\mathrm{H}$ & 1.096 & 5.164 & 0.892 & \\
\hline 30.2 & $C-C$ & 1.461 & 5.242 & 1.038 & \\
\hline 30.3 & $C \equiv C$ & 1.209 & 17.153 & 2.131 & \\
\hline 31.1 & $\mathrm{C}-\mathrm{H}$ & 1.065 & 6.493 & 0.853 & \\
\hline 31.2 & $C \equiv C$ & 1.212 & 16.679 & 2.406 & \\
\hline 31.3 & $C-C$ & 1.369 & 7.685 & 1.282 & \\
\hline 32.1 & $\mathrm{C} 2-\mathrm{H}$ & 1.080 & 5.828 & 0.944 & \\
\hline 32.2 & $\mathrm{C} 1-\mathrm{H}$ & 1.079 & 5.913 & 0.939 & \\
\hline 32.3 & $\mathrm{C} 2-\mathrm{C} 2$ & 1.435 & 5.573 & 1.107 & yes \\
\hline 32.4 & $\mathrm{C} 1=\mathrm{C} 2$ & 1.361 & 8.028 & 1.322 & yes \\
\hline 32.5 & $\mathrm{C} 1-\mathrm{O}$ & 1.364 & 5.589 & 1.321 & yes \\
\hline 33.1 & $\mathrm{C} 2-\mathrm{H}$ & 1.081 & 5.794 & 0.952 & \\
\hline 33.2 & $\mathrm{C} 1-\mathrm{H}$ & 1.080 & 5.847 & 0.943 & \\
\hline 33.3 & $\mathrm{C} 2-\mathrm{C} 2$ & 1.425 & 5.808 & 1.147 & yes \\
\hline 33.4 & $\mathrm{C} 1=\mathrm{C} 2$ & 1.378 & 7.376 & 1.279 & yes \\
\hline 33.5 & $\mathrm{C} 1-\mathrm{N}$ & 1.375 & 6.463 & 1.330 & yes \\
\hline 33.6 & $\mathrm{~N}-\mathrm{H}$ & 1.007 & 7.523 & 1.268 & \\
\hline 34.1 & C1-O & 1.345 & 5.881 & 1.378 & yes \\
\hline 34.2 & $\mathrm{C} 2-\mathrm{H}$ & 1.079 & 5.909 & 0.946 & \\
\hline 34.3 & $\mathrm{C} 3-\mathrm{H}$ & 1.082 & 5.783 & 0.924 & \\
\hline 34.4 & $\mathrm{C} 1=\mathrm{C} 2$ & 1.360 & 8.024 & 1.317 & yes \\
\hline 34.5 & $\mathrm{C} 2-\mathrm{C} 3$ & 1.424 & 5.801 & 1.120 & yes \\
\hline 34.6 & C3-N & 1.313 & 8.232 & 1.553 & yes \\
\hline 34.7 & $\mathrm{O}-\mathrm{N}$ & 1.399 & 3.713 & 1.286 & yes \\
\hline 35.1 & $\mathrm{C}-\mathrm{H}$ & 1.082 & 5.816 & 0.925 & \\
\hline 35.2 & $C=C$ & 1.335 & 9.469 & 1.382 & yes \\
\hline 35.3 & $C-C$ & 1.491 & 4.268 & 0.907 & yes \\
\hline 35.4 & $C=0$ & 1.198 & 13.595 & 2.205 & \\
\hline 35.5 & $\mathrm{C}-\mathrm{O}$ & 1.394 & 3.835 & 1.178 & yes \\
\hline 36.1 & $\mathrm{C} 2-\mathrm{H}$ & 1.084 & 5.679 & 0.933 & \\
\hline 36.2 & $\mathrm{C} 1-\mathrm{H}$ & 1.081 & 5.827 & 0.932 & \\
\hline 36.3 & $\mathrm{C} 2-\mathrm{C} 2$ & 1.430 & 5.690 & 1.108 & yes \\
\hline 36.4 & $\mathrm{C} 1=\mathrm{C} 2$ & 1.367 & 7.657 & 1.311 & yes \\
\hline 36.5 & C-S & 1.736 & 3.653 & 0.755 & yes \\
\hline 37.1 & $\mathrm{C}-\mathrm{He}$ & 1.097 & 5.115 & 0.908 & \\
\hline 37.2 & $\mathrm{C}-\mathrm{Ha}$ & 1.100 & 5.016 & 0.901 & \\
\hline 37.3 & $C-C$ & 1.537 & 3.923 & 0.833 & yes \\
\hline 38.1 & $\mathrm{C}-\mathrm{H}$ & 1.086 & 5.564 & 0.930 & \\
\hline 38.2 & C-C & 1.396 & 6.600 & 1.197 & yes \\
\hline 39.1 & $\mathrm{~N}(\mathrm{~N}) \mathrm{OA} \ldots \mathrm{HT}$ & 1.923 & 0.178 & 0.088 & \\
\hline 39.2 & НА...ОT & 2.798 & 0.059 & 0.013 & \\
\hline 39.3 & NA...HT & 1.796 & 0.280 & 0.128 & \\
\hline
\end{tabular}


$\begin{array}{lllll}40.1 & \mathrm{OG} . . . \mathrm{HC}(\mathrm{N}) & 1.748 & 0.274 & 0.134\end{array}$

$\begin{array}{lllll}40.2 & \text { (N)HG...OC } & 1.902 & 0.250 & 0.092\end{array}$

$\begin{array}{lllll}40.3 & \text { HG...NC } & 1.895 & 0.467 & 0.099\end{array}$ 


\section{$14 \mathrm{~B}_{2} \mathrm{H}_{6}$, cyclopropane, metallocene, agostic interac- tion}

The interactions in $\mathrm{B}_{2} \mathrm{H}_{6}$, cyclopropane and [cyclopentadienyl... $\mathrm{Zn}^{2+}$ ] complex have been identified and characterized thanks to the full IGM approach with $\delta g=\left|\nabla \rho^{I G M}\right|-|\nabla \rho|$. Within this full scheme, in the IGM, no atom is allowed to interact with others. Hence, all the interactions are revealed by $\delta g$.

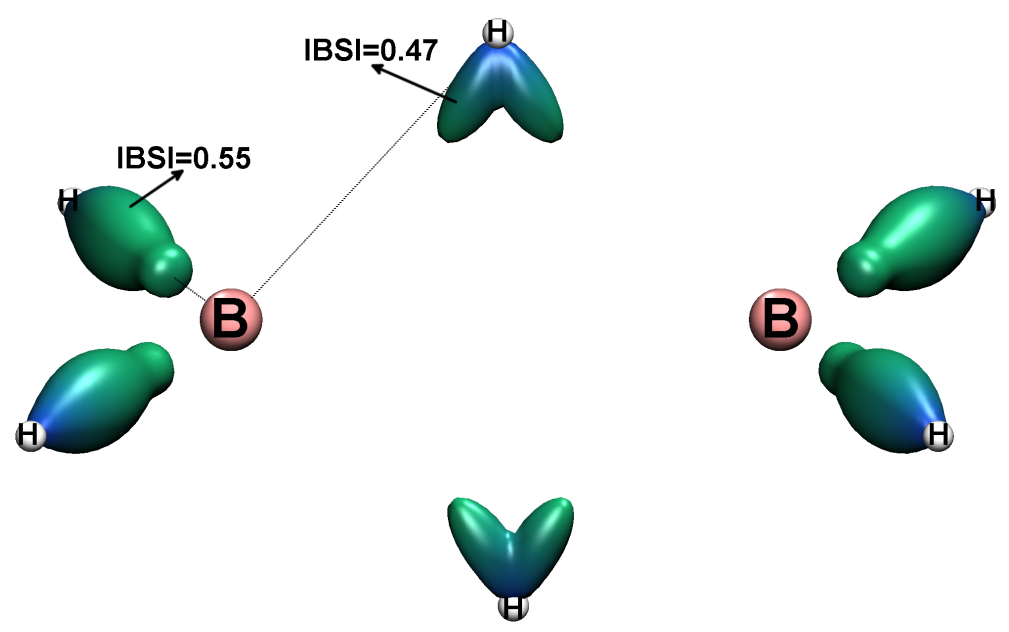

Figure S8: $\mathrm{B}_{2} \mathrm{H}_{6} ; \delta_{g}=0.21$ a.u. $3 \mathrm{D}$ isosurfaces; color coding in the range $-0.5<\operatorname{sign}\left(\lambda_{2}\right) \rho$ $<0.5$ a.u.; M06-2X 6-31G** level of theory. 


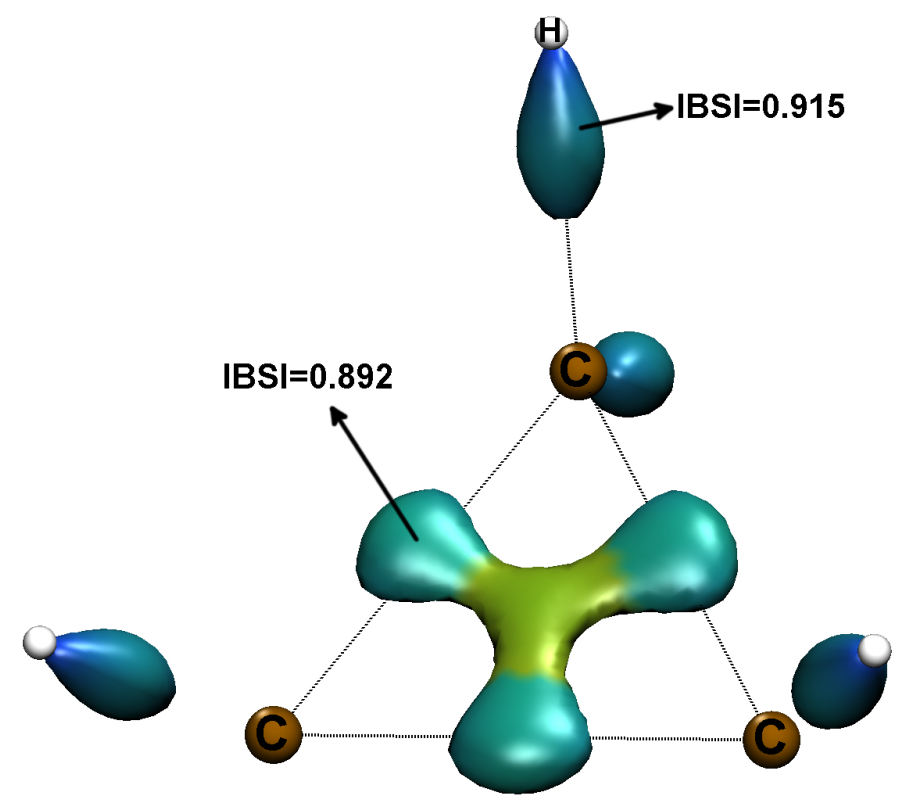

Figure S9: $\mathrm{C}_{3} \mathrm{H}_{6} ; \delta_{g}=0.38$ a.u. $3 \mathrm{D}$ isosurfaces; color coding in the range $-0.5<\operatorname{sign}\left(\lambda_{2}\right) \rho$ $<0.5$ a.u.; M06-2X 6-31G** level of theory.

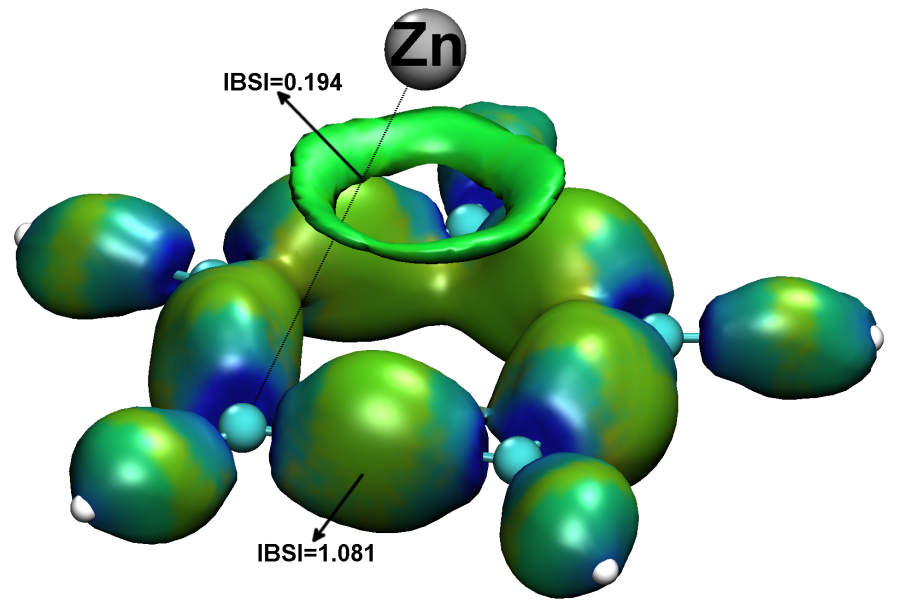

Figure S10: [Cyclopentadienyl anion ... $\mathrm{Zn}^{2+}$ ] complex; $\delta_{g}=0.12$ a.u. 3D isosurfaces; color coding in the range $-0.5<\operatorname{sign}\left(\lambda_{2}\right) \rho<0.5$ a.u.; M06-2X 6-31G** level of theory. 


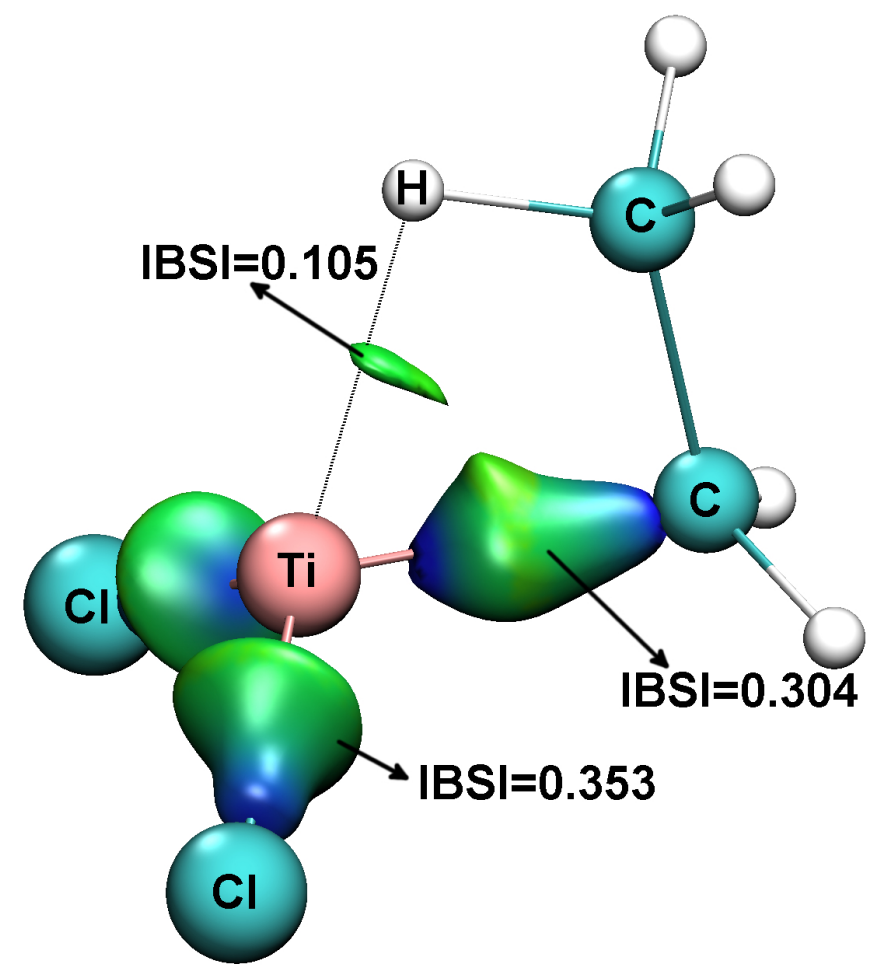

Figure S11: $\left[\mathrm{Ti}\left(\mathrm{Cl}_{2}\right) \mathrm{C}_{2} \mathrm{H}_{5}\right]^{+} ; \delta_{g}=0.08$ a.u. 3D isosurfaces; color coding in the range $-0.5<$ $\operatorname{sign}\left(\lambda_{2}\right) \rho<0.5$ a.u.; DFT B3LYP $/ 6-311++\mathrm{G}(2 \mathrm{~d}, 2 \mathrm{p})$ level of theory.

The interactions around the titanium atom in the $\left[\left(\mathrm{Cl}_{2}\right) \mathrm{TiC}_{2} \mathrm{H}_{5}\right]^{+}$complex have been probed and characterized thanks to the IGM $\delta g^{\text {inter }}$ scheme by considering two fragments: the titanium and the rest of the molecule. It reveals an agostic interaction with the contragradience domain being located between $\mathrm{C}-\mathrm{H}$ and the titanium atom.

\section{References}

(1) Rubez, G.; Etancelin, J.-M.; Vigouroux, X.; Krajecki, M.; Boisson, J.-C.; Hénon, E. J. Comput. Chem. 2017, 38, 1071.

(2) Lepetit, C.; Fau, P.; Fajerwerg, K.; Kahn, M.; Silvi, B. Coord. Chem. Rev. 2017, 345, 150.

(3) Zou, W.; Kalescky, R.; Kraka, E.; Cremer, D. Relating normal vibrational modes to local 
vibrational modes with the help of an adiabatic connection scheme. J. Chem. Phys. 2012, 137, 084114-1-084114-11. 